\title{
Pigments - Mercury-based red (cinnabar-vermilion) and white (calomel) and their degradation products
}

\author{
Elisabetta Gliozzo ${ }^{1}$ (D) \\ Received: 22 January 2021 / Accepted: 30 June 2021 / Published online: 30 October 2021 \\ (C) The Author(s) 2021
}

\begin{abstract}
This article summarises the history of cinnabar, from its first uses in burials to modern oils on canvas. After a brief introduction on mercury and contamination issues, the article gets to the heart of the topic. First, mercury-based minerals significant for studying pigments, i.e. cinnabar, metacinnabar, hypercinnabar and calomel, are presented. Structural information and properties precede an overview of the geographic distribution of cinnabar deposits. The following section addresses the multiple uses of cinnabar, divided into funerary use, decorative use, lustre and Chinese lacquer production. The use of cinnabar for writing (ink), medicine and cosmetics is briefly described, and a shortlist of uncommon finds is further provided. The following section approaches inherent but less known topics such as cinnabar procurement, trade, production technology, application and alteration. An entire section is dedicated to calomel before concluding with an overview of the analytical methods for the characterisation and provenance investigation of cinnabar.
\end{abstract}

Keywords Cinnabar-metacinnabar-hypercinnabar · Vermilion and pigment analysis · White mercury and calomel, corderoite and terlinguaite $\cdot$ Archaeometry and archaeology

\section{Premise}

This Topical Collection (TC) covers several topics in the field of study, in which ancient architecture, art history, archaeology and material analyses intersect. The chosen perspective is that of a multidisciplinary scenario, capable of combining, integrating and solving the research issues raised by the study of mortars, plasters and pigments (Gliozzo et al. 2021).

The first group of contributions explains how mortars have been made and used through the ages (Arizzi and Cultrone 2021; Ergenç et al. 2021; Lancaster 2021; Vitti 2021). An insight into their production, transport and on-site organisation is further provided by DeLaine (2021). Furthermore, several issues concerning the degradation and conservation of mortars and plasters are addressed from practical and technical standpoints (La Russa and Ruffolo 2021; Caroselli et al. 2021).

This article is part of the Topical Collection on Mortars, plasters and pigments: research questions and answers

Elisabetta Gliozzo

elisabetta.gliozzo@uniba.it; elisabetta.gliozzo@gmail.com

1 Department of Humanities, University of Bari, Bari, Italy
The second group of contributions is focused on pigments, starting from a philological essay on terminology (Becker 2021). Three archaeological reviews on prehistoric (Domingo Sanz and Chieli 2021), Roman (Salvadori and Sbrolli 2021) and medieval (Murat 2021) wall paintings clarify the archaeological and historical/cultural framework. A series of archaeometric reviews illustrate the state of the art of the studies carried out on Fe-based red, yellow and brown ochres (Mastrotheodoros et al. 2021); Cubased greens and blues (Švarcová et al. 2021); As-based yellows and reds (Gliozzo and Burgio 2021); Pb-based whites, reds, yellows and oranges (Gliozzo and Ionescu 2021); Hg-based red and white (this paper) and organic pigments (Aceto 2021). An overview of the use of inks, pigments and dyes in manuscripts, their scientific examination and analysis protocol (Burgio 2021) as well as an overview of glass-based pigments (Cavallo and Riccardi 2021) are also presented. Furthermore, two papers on cosmetic (Pérez-Arantegui 2021) and bioactive (antibacterial) pigments (Knapp et al. 2021) provide insights into the variety and different uses of these materials.

\section{Introduction}

Mercury is the only metal (chalcophile) that occurs in liquid form at room temperature. Due to its colour and form, it has 
also been called liquid silver, hydrargyrum and, especially, quicksilver, a term, this latter, mainly used by geologists involved in the study of its occurrence and mode of transport (especially in the 1940s/1950s, e.g., Dreyer 1940a, 1940b; Ross 1942; Krauskopf 1951).

Mercury is classified as a rare element as it is present in low concentrations in the Earth's upper $(\sim 0.05 \mathrm{ppm})$, middle $(0.0079 \mathrm{ppm})$ and lower $(0.014 \mathrm{ppm})$ crust (Rudnick and Gao 2004).

Its multiple uses ranged from measurement tools such as thermometers, barometers and pressure-sensing devices to dental amalgam, batteries, lubrication oils, lamps and other industrial processes and products.

Despite its varied and widespread use, mercury is toxic, and, for this reason, it has been banned for paints since 1990, while mercuric chloride is still used as a pesticide and a disinfectant. The WHO identifies mercury "as one of the top ten chemicals or groups of chemicals of major public health concern", that "may have toxic effects on the nervous, digestive and immune systems, and on lungs, kidneys, skin and eyes" (https://www.who.int/news-room/fact-sheets/detail/ mercury-and-health). However, natural cinnabar is less toxic than organic mercury (methyl mercury or dimethyl mercury) or liquid mercury. At the same time, the process for mercury extraction can be highly toxic (esp. mercury vapours) as well as the accumulation of methylmercury $\left(\left[\mathrm{CH}_{3} \mathrm{Hg}\right]^{+}\right)$, which is mainly formed by the action of anaerobic bacteria ${ }^{1}$ (see, e.g., Manceau et al. 2015 and Supplementary materials Appendix 1). Environmental issues have stimulated the creation of an extensive body of literature both focused on specific case studies related to the mining exploitation of geological deposits and of a more general nature, aimed at unravelling the main processes (Burkstaller et al. 1975; Rytuba 2000, 2003; Horvat 2005; Holley et al. 2007; Levin 2014; Chen et al. 2017).

The first category includes such a large number of research papers that it is impossible to mention them all in this contribution; however, it is useful to point out two important aspects. Firstly, mercury pollution has an extremely vast range. Therefore, it is possible to find clear signs of pollution in soils, waters, flora, fauna and atmosphere at considerable distances from the extraction area, especially in correspondence of river courses. Secondly, ancient and modern working places are often mentioned and investigated in these studies, near and far from the mining district; therefore, they represent "a mine of information" for archaeometric studies on provenance and technology.

Indeed, mercury poisoning is thoroughly documented by ancient literary sources and archaeometric investigations. For example, cases are reported for the Late Neolithic/Chalcolithic

\footnotetext{
${ }^{1}$ For example, the danger of high levels of mercury in fish is a sadly known phenomenon.
}

(5400-4100 BP) population of southern Portugal (Emslie et al. 2015), for miners buried at the archaeological site of Ranas in the Sierra Gorda Querétaro (Mexico; Serrana culture $)^{2}$ and for Southern Denmark and Northern Germany medieval population (Rasmussen et al. 2015).

This review will tackle the "cinnabar" theme from multiple perspectives, based above all on its characteristics and use. The main objective is to provide the broadest possible framework for the study of cinnabar rather than address each topic in detail. While the dimensions of a single article would not allow a comprehensive discussion, it is possible to provide an overview of the state-of-the-art to guide both the study and the bibliographic search.

\section{Mercury in naturally occurring minerals}

Mercury compounds mainly include sulphides (e.g., cinnabar, $\mathrm{HgS}$ ), chlorides (e.g., mercuric chloride, $\mathrm{HgCl}_{2}$ and mercurous chloride $\mathrm{Hg}_{2} \mathrm{Cl}_{2}$ known as calomel), halides (e.g., terlinguaite, $\mathrm{Hg}_{2} \mathrm{ClO}$; corderoite and kenhsuite, $\mathrm{Hg}_{3} \mathrm{~S}_{2} \mathrm{Cl}_{2}$ ), oxides (e.g., montroydite, $\mathrm{HgO}$ ), along with natural alloys (e.g., leadamalgam, $\mathrm{HgPb}_{2}$ ), phosphates (e.g., artsmithite, $\mathrm{Hg}_{4} \mathrm{Al}\left(\mathrm{PO}_{4}\right)_{1.74}(\mathrm{OH})_{1.78}$ ), silicates (e.g., edgarbaileyite, $\mathrm{Hg}_{6} \mathrm{Si}_{2} \mathrm{O}_{7}$ ), arsenates (e.g., chursinite, $\mathrm{Hg}_{2} \mathrm{AsO}_{4}$ ), carbonates (e.g., peterbaylissite, $\mathrm{Hg}_{3}\left(\mathrm{CO}_{3}\right)(\mathrm{OH}) \cdot 2\left(\mathrm{H}_{2} \mathrm{O}\right)$ ) and acetates (e.g., mercuric acetate, $\mathrm{HgC}_{4} \mathrm{H}_{6} \mathrm{O}_{4}$ ).

The sulphides are the most abundant, and, among them, the three HgS polymorphs - namely cinnabar, metacinnabar and hypercinnabar - prevail. Among chlorides and halides, calomel, terlinguaite and kenhsuite are significant in the Cultural Heritage studies because they are the only ones found in artworks to date. Among natural alloys, the amalgams have a technological and historical interest (Giumlia-Mair et al. 2014) that, however, go beyond the objectives of this review.

A shortlist of research articles that may help study $\mathrm{Hg}$ bearing phases is provided in Supplementary materials Appendix 1.

\section{Cinnabar, metacinnabar, hypercinnabar and calomel}

Cinnabar $(\alpha-\mathrm{HgS})$ is bright red mercury sulphide $(\mathrm{HgS}$; Fig. 1 ), also named $\kappa \iota \nu \nu \alpha \dot{\alpha} \beta \rho \iota$ (kinnabari) in Greek, minium cinnabaris in Latin and šangarf or sim- šangarf in Persian (the Arabic zinjifra should correspond to red lead). On the etymology of cinnabar and the corresponding names in Latin, Persian and Arabic, the reader is referred to the detailed study by Rosó (2018) and Becker (2021 in this TC). On the distinction between inorganic cinnabar and dragon's blood, or

\footnotetext{
$\overline{2}$ A well-known cinnabar Mesoamerican mining area between the $2^{\text {nd }}$ and $14^{\text {th }}$ century AD (Ávila et al. 2014).
} 
Fig. 1 Macrophotos of $\mathbf{A}$ cinnabar from the Almadén Mine, Ciudad Real, Castile-La Mancha, Spain (specimen and photo: fabreminerals.com - Mindat.org Photo ID: 56508); B cinnabar from the Tongren Mine, Bijiang District, Guizhou, China (Arkenstone specimen. Photo credits: Rob Lavinsky, irocks. com - Mindat.org Photo ID: 206087); C cinnabar from Pozo de San Teodoro, Almadén district (specimen and photo:

fabreminerals.com - Mindat.org Photo ID: 942728 ); D cinnabar crystals on pyritic matrix from Las Cuevas Mine, Almadén district, Spain (photo credits: Carlos Gonzalez Bargueño Mindat.org Photo ID: 867406); E metacinnabar with pyrite from $\mathrm{El}$ Entredicho Mine, Almadén district (photo credits: Borja Sainz de Baranda Graf - Mindat.org Photo ID: 937144); F distorted cluster of cubo-octahedral metacinnabar crystals, intermixed with hypercinnabar, on quartz matrix, from the Mount Diablo Mine, Clayton, CA, USA (photo and specimen, Jeff Weissman - ID 1035520); G intermixed, highly modified and distorted trigonal/ hexagonal appearing hypercinnabar crystals with cubic metacinnabar crystals, with pale yellow flaky copiapite crusts on crystalline quartz (photo and specimen, Jeff Weissman Mindat.org Photo ID: 1035520); H calomel from Terlingua Mining District, TX, USA (Arkenstone specimen. Photo credits: Rob Lavinsky, irocks.com - Mindat. org Photo ID: 716834). The CCBY license does not supersede previously copyrighted material; therefore, these images remain under owners' copyright

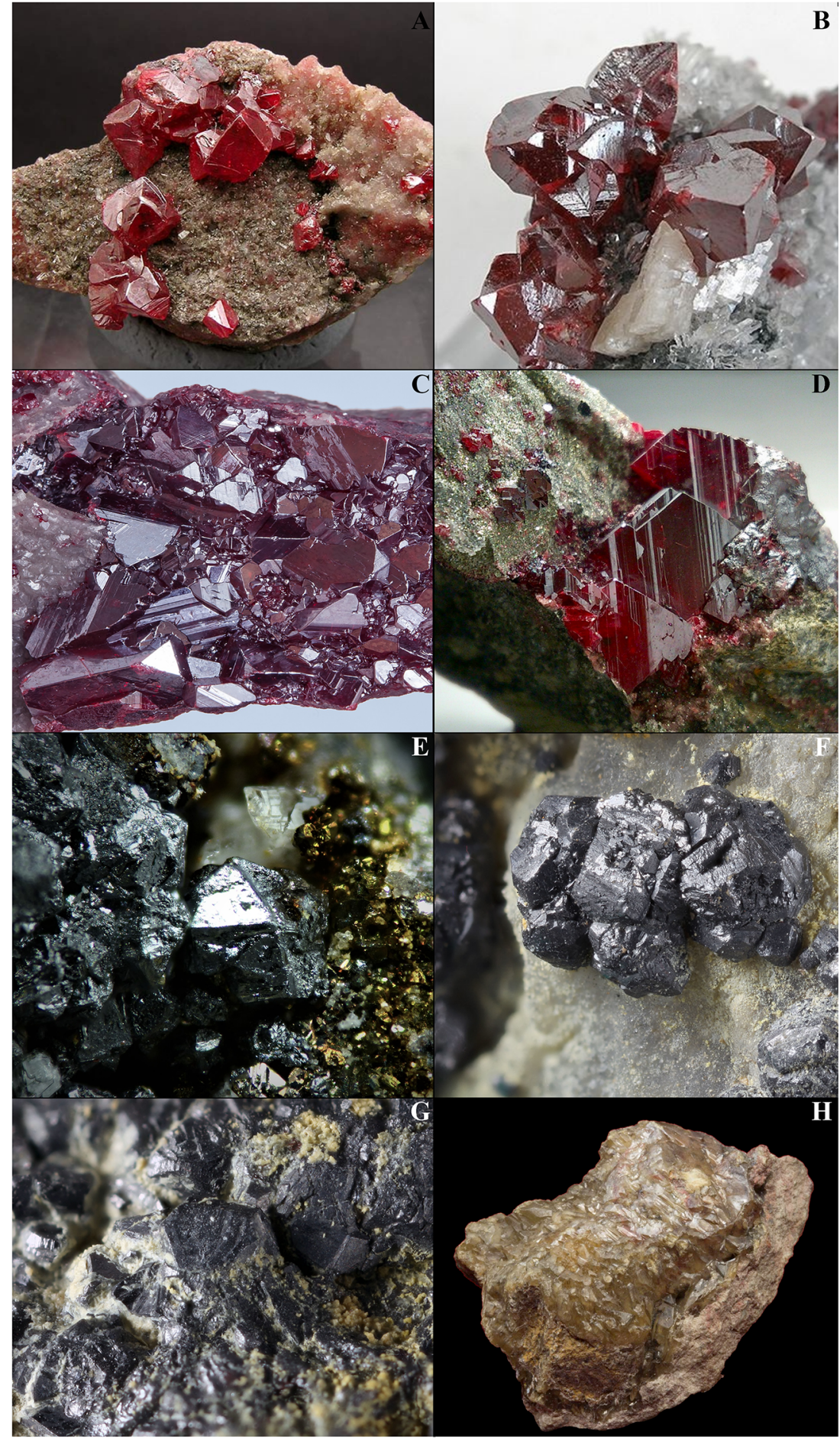

organic cinnabar, the reader may consult both Rosół (2018) and Trinquier (2013).

Studied since the early decades of the 1900s (Buckley and Vernon 1925; Olhausen 1925; Ramsdell 1925), its structure has been further provided by Berry and Thompson (1962), Auvray and Genet (1973) and Schleid et al. (1999).
Cinnabar is a trigonal phase (Table 1; Fig. 2), constituted by helical chains of -S-Hg-S-Hg-.

Metacinnabar $(\beta-\mathrm{HgS})$ is an isometric black mineral with a zincblende structure (Table 1; Figs. 1-2), whose structure has been investigated by Lehman (1924), Wyckoff (1963) and Ballirano et al. (2013). 
Table 1 Space groups and structural parameters of $\mathrm{Hg}$-minerals mentioned in text

\begin{tabular}{|c|c|c|c|c|c|c|}
\hline & Space group & $a$ & $c$ & $\mathrm{~V}$ & $Z$ & Reference \\
\hline \multirow[t]{7}{*}{ Cinnabar (trigonal) } & \multirow[t]{7}{*}{$P 3_{2} 21(154)$} & 4.16 & 9.54 & 142.977 & 3 & Buckley and Vernon 1925 \\
\hline & & 4.15 & 9.51 & 141.843 & 3 & Ramsdell 1925 \\
\hline & & 4.14 & 9.49 & - & 3 & Berry and Thompson 1962 \\
\hline & & 4.148 & 9.492 & - & - & Mikolaichuk and Dutchak 1965 \\
\hline & & 4.145 & 9.496 & 141.293 & 3 & Auvray and Genet 1973 \\
\hline & & $4.1489(2)$ & $9.4947(5)$ & - & - & Schleid et al. 1999 \\
\hline & & $4.1489(2)$ & $9.4947(5)$ & - & 3 & Ballirano et al. 2013 \\
\hline \multirow[t]{4}{*}{ Metacinnabar (isometric) } & \multirow[t]{4}{*}{$F-43 m(216)$} & 5.858 & $=$ & 201.024 & 4 & Lehmann 1924 \\
\hline & & 5.8517 & $=$ & 200.376 & 4 & Wyckoff 1963 \\
\hline & & $5.850(4)$ & $=$ & - & - & Mikolaichuk and Dutchak 1965 \\
\hline & & $5.8461(4)$ & $=$ & - & - & Ballirano et al. 2003 \\
\hline \multirow[t]{2}{*}{ Hypercinnabar (hexagonal) } & \multirow[t]{2}{*}{-} & $6.86(1)$ & $14.07(7)$ & - & - & Mikolaichuk and Dutchak 1965 \\
\hline & & $7.01(3)$ & $14.13(7)$ & 601.32 & 12 & Potter and Barnes 1978 \\
\hline \multirow[t]{5}{*}{ Calomel (tetragonal) } & \multirow[t]{5}{*}{ I4/mmm (139) } & 4.47 & 10.89 & 217.592 & 2 & Havighurst 1926 \\
\hline & & 4.464 & 10.9 & 217.208 & 2 & Hylleraas 1926 \\
\hline & & 4.478 & 10.91 & 218.773 & 2 & Wyckoff 1963 \\
\hline & & $4.482(2)$ & $10.910(3)$ & - & - & Dorm 1971 \\
\hline & & $4.4795(5)$ & $10.9054(9)$ & $218.83(8)$ & 2 & Calos et al. 1989 \\
\hline
\end{tabular}

Hypercinnabar $(\gamma-\mathrm{HgS})$ is a hexagonal phase (Table 1; Fig. 2), first identified by Mikolaichuk and Dutchak (1965). Later, it was found by Protobyakonova et al. (1971) in Russia and approved by the IMA commission in 1978 (Potter and Barnes 1978) as a new HgS polymorph. This black mineral -which may contain minor Fe- has an undefined hexagonal structure (Table 1; Fig. 2). An intermediate pseudocubic phase (XHgS) has been further observed by Bell et al. (2010) between 467 and $552 \mathrm{~K}$, i.e. below the metacinnabar $\rightarrow$ cinnabar transition temperature.

Calomel $\left(\mathrm{Hg}_{2} \mathrm{Cl}_{2}\right)$ is likely the most important compound in which $\mathrm{Hg}$ is univalent. From white to yellowish-grey, grey and brown, its tetragonal structure (Figs. 1 and 3) was first investigated by Havighurst (1926) and Hylleraas (1926) and then later by Wyckoff (1963), Dorm (1971) and Calos et al. (1989).

It is curious to note that the English word calomel ( $\kappa \alpha \lambda \circ \mu \varepsilon \dot{\lambda} \alpha v o$, calomelano in Greek) derives from the Greek $\kappa \alpha \lambda$ ó (kalos, beautiful) and $\mu \varepsilon \dot{\lambda} \alpha \alpha v o \varsigma$ (melanos, black). Swiderski (2008) narrates that according to Pereira (1849-1850) the name is "referred to $\mathrm{Dr}$. Theodore de Mayerne's black servant, who was so skilled in preparing the drug that Mayerne called it "beautiful black" in praise of both drug and servant". Soon after, Swiderski reconstructs the history of the name's assignment and, above all, traces the significant correlation between the term and the production of mercury sublimates. Considering the medicinal use of sublimates, the author observes the convenience of a term recalling beauty and honey ( $\mu \varepsilon \varepsilon^{\prime} \iota$, meli, honey) compared to one that explicitly mentions mercury. The latter would undoubtedly have been more frightening for a patient than the former. In any case, while the name calomel does not refer to the natural whitish mineral, it reflects the characteristic blackening obtained with exposure to light (photosensitivity) or ammonia.

Apart from the literature mentioned above, the phase relations in the mercury-sulphur system have been chiefly investigated by Dickson and Tunell (1954, 1959), Kullerud (1965), Ohmiya (1974) and, above all, by Potter and Barnes (1978), Mel'chakova and Kiseleva (1990), Sharma et al. (1993) and Ballirano et al. (2013). Stable under ambient conditions, cinnabar converts to metacinnabar between 315 and $345 \pm 2^{\circ} \mathrm{C}$ (depending on $\mathrm{Hg} \%$; see Potter and Barnes 1978) or even higher at $673^{\circ}$ $\mathrm{K}$ in an oxidising atmosphere $\left(=399.8^{\circ} \mathrm{C}\right.$ in Ballirano et al. 2013). In turn, metacinnabar converts to hypercinnabar between 470 and $481^{\circ} \mathrm{C}$. Above these temperatures, hypercinnabar is stable up to $788^{\circ}$ or $804^{\circ} \mathrm{C}$, still depending on $\mathrm{Hg} \%$. The diagrams in Fig. 4 show that the stability of the various phases is directly linked to the stoichiometry (i.e. purity) of the HgS. Moreover, the variation in temperatures is also due to different experimental setups (e.g., in situ, ex situ, under vacuum, in an oxidising atmosphere, etc.). 


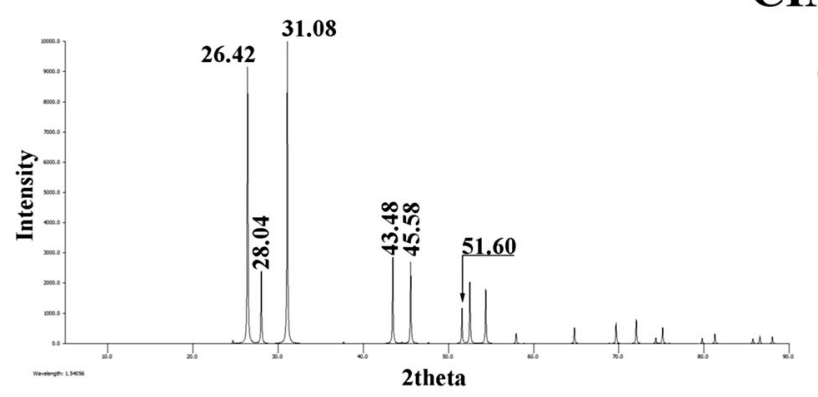

\section{CINNABAR}

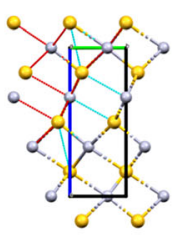

A
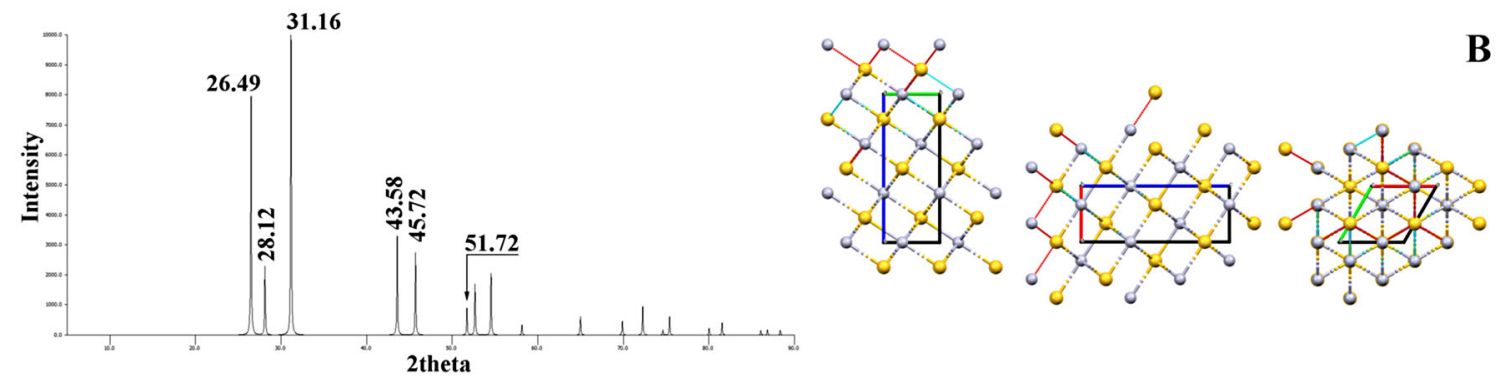

B
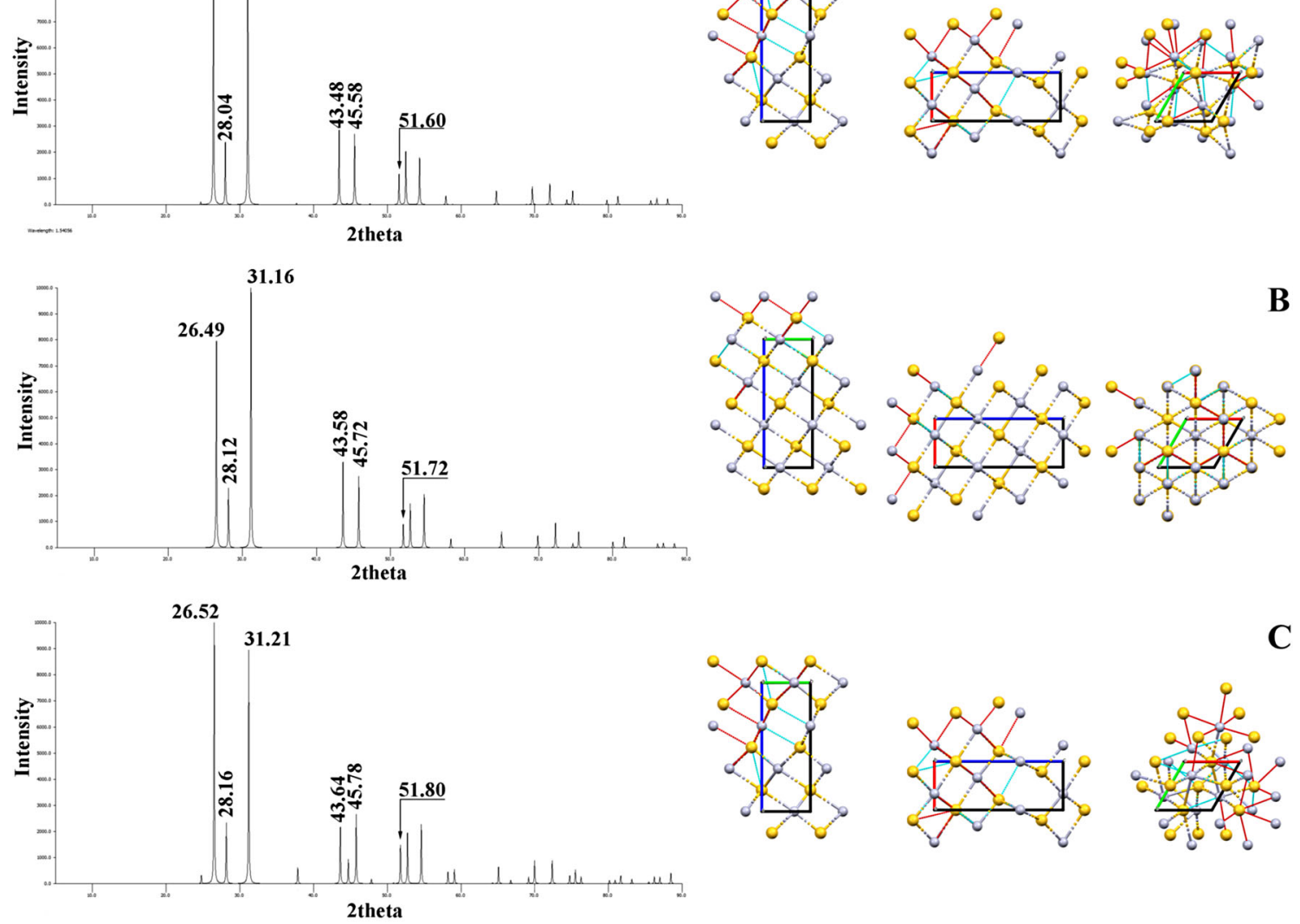

C

\section{METACINNABAR}
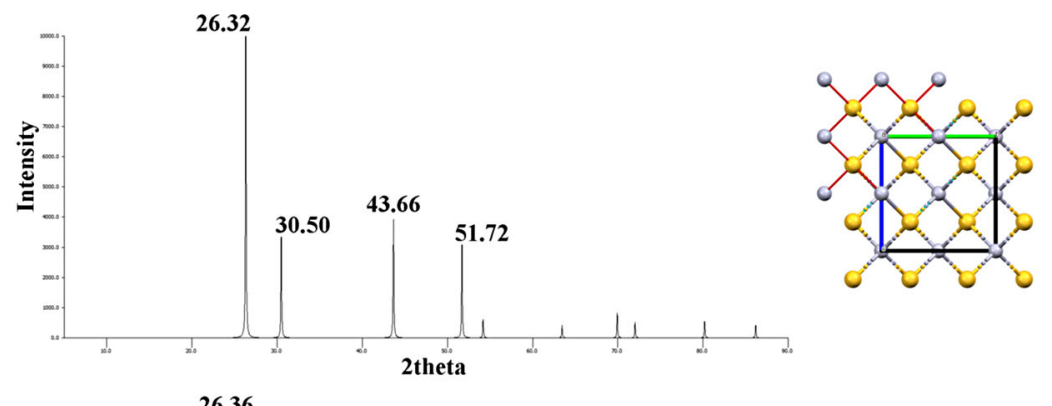

D

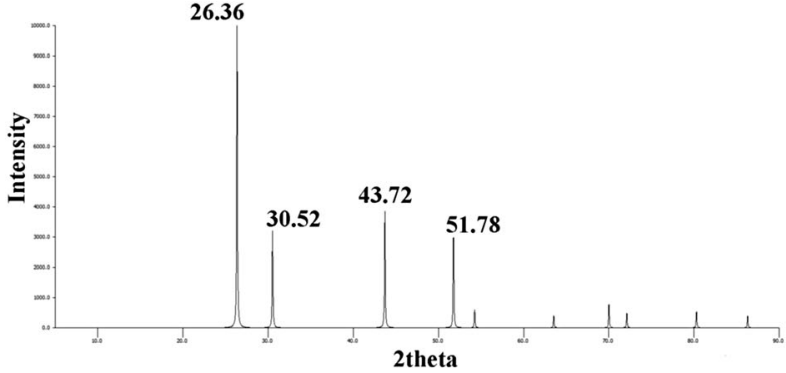

$\mathbf{E}$

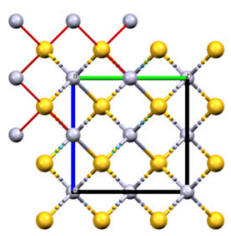

Fig. 2 XRD patterns $(\mathrm{Cu}-\mathrm{K} \alpha$ ) and (ball-stick) packing along a, b and c (unit cell shown) of cinnabar and metacinnabar. A Buckley and Vernon (1925); B Ramsdell (1925); C Auvray and Genet (1973); D Lehmann (1924); E Wyckoff (1963) 

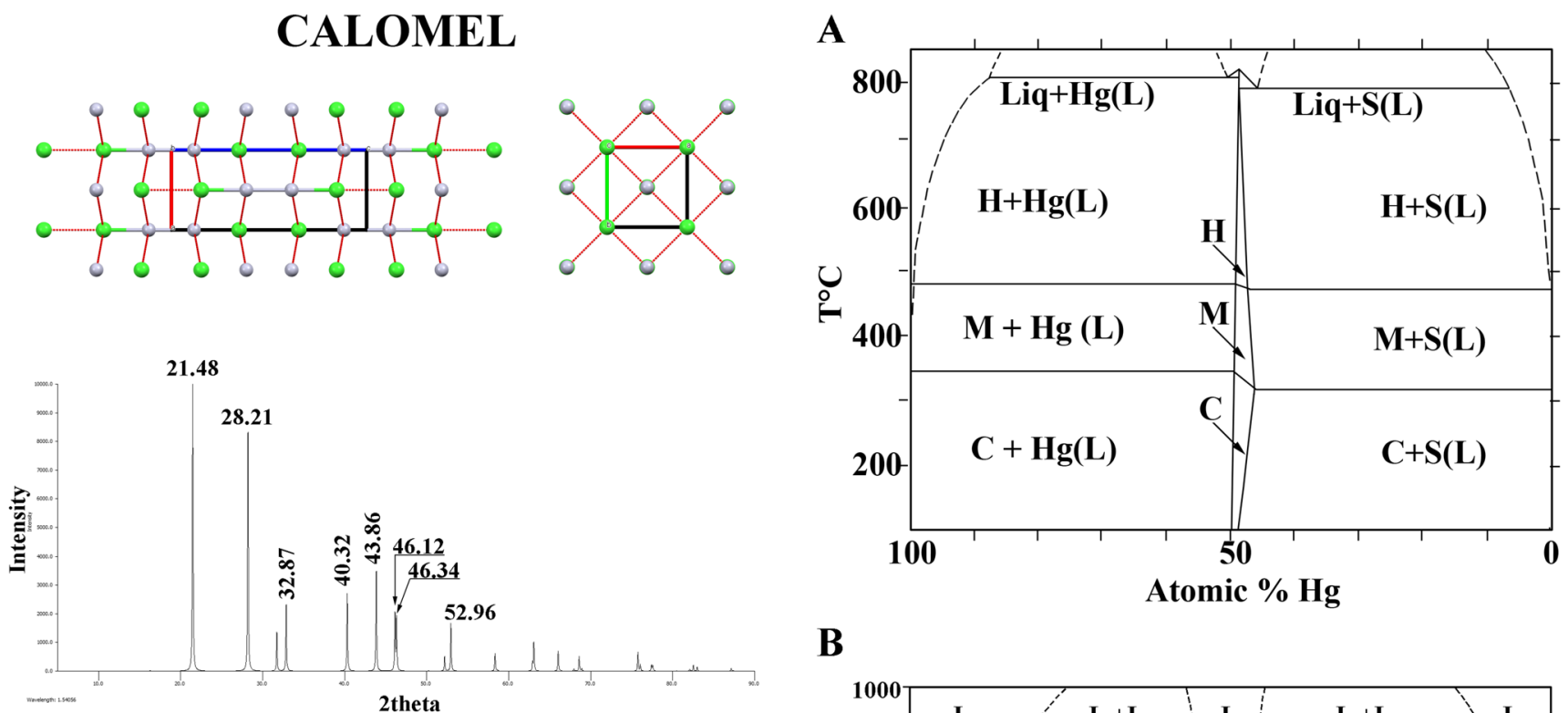

B
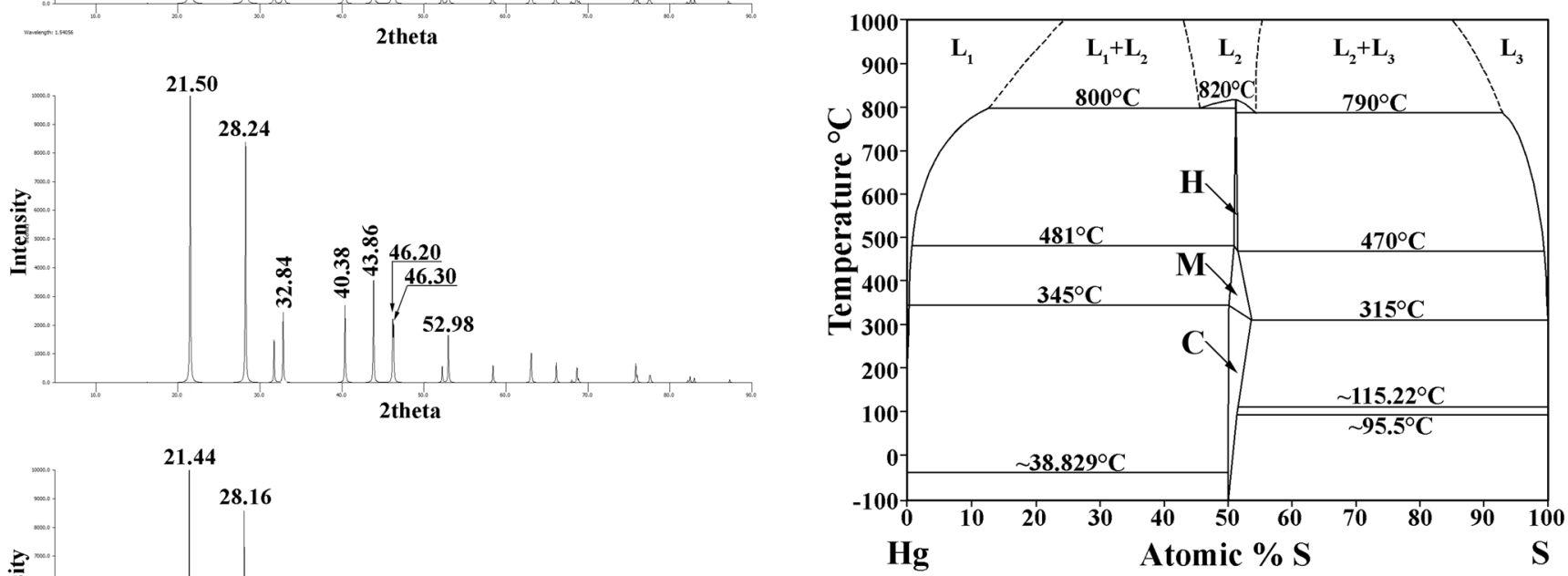

C

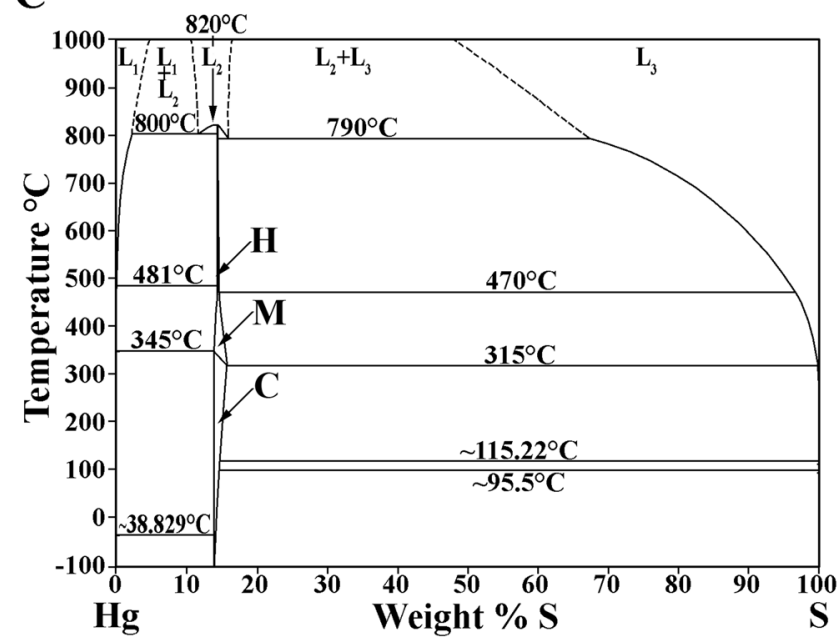

\section{The geographic distribution of cinnabar deposits}

The geographic distribution of cinnabar is worldwide. Mindat database enlists 2694 localities in 66 countries, including both outcrops and mines: Afghanistan (27), Argentina (2), Australia (4), Austria (118), Azerbaijan (1), Belgium (9),
Fig. 4 Phase relations. A Modified from Potter and Barnes (1978); B-C simplified after Sharma et al. (1993) (C=cinnabar; $\mathrm{M}=$ metacinnabar; $\mathrm{H}=$ hypercinnabar)

Bolivia (12), Bosnia and Herzegovina (4), Brazil (3), Bulgaria (5), Canada (20), Chile (28), China (202), 
Colombia (2), Croatia (1), Czech Republic (7), Ecuador (1), Fiji (1), France (21), Georgia (6), Germany (89), Greece (4), Hungary (35), India (1), Indonesia (7), Iran (3), Ireland (1), Italy (88), Japan (34), Kazakhstan (2), Korea (1), Kyrgyzstan (6), Malaysia (3), Mexico (83), Mongolia (5), Montenegro (1), Morocco (3), Myanmar (1), Namibia (1), New Zealand (27), North Macedonia (5), Norway (1), Pacific Ocean (1), Papua New Guinea (1), Peru (5), Philippines (3), Poland (8), Portugal (3), Romania (6), Russia (56), Serbia (4), Slovakia (96), Slovenia (3), South Africa (6), Spain (77), Sweden (1), Switzerland (9), Taiwan (5), Tajikistan (4), Tunisia (2), Turkey (10), UK (22), Ukraine (8), USA (1481), Uzbekistan (6) and Zimbabwe (2).

These occurrences and relative quantifications must serve exclusively as an example as they reflect the state of the art of the studies carried out in each country. On the other hand, the numbers account for more modern exploitation than the actual extent of the deposits. Moreover, some attestations are missing, while others refer to the same mining district.

The list is not exhaustive but it gives an idea of the distribution of cinnabar. In support of what can be easily found online, Fig. 5 illustrates the distribution of the main geological deposits of cinnabar. The occurrences have been drawn based on $>250$ papers indexed by Scopus; therefore, some information is missing but can be recovered on the mindat.org database. In Supplementary materials Table 1, the deposits shown in Fig. 5 are listed together with the corresponding bibliographic reference.
As for the associations, cinnabar is frequently found in gold/silver/arsenic/antimony deposits. Apart from native elements, the most typical association is with stibnite, followed by pyrite, sphalerite, chalcopyrite, galena, arsenopyrite, realgar, marcasite, orpiment, tetrahedrite and Hg-bearing halides. Scheelite, cerussite, pyrrhotite, acanthite, siderite, anglesite, chalcocite, covellite and pyromorphite are other minor phases frequently found in association with cinnabar. Ag-Hg amalgam and rare phases such as tellurides and sulphobismuthides have also been found associated in $\mathrm{Hg}$-deposits.

Worthy of mention are the numerous (but apparently rare) Hg-bearing phases discovered in Clear Creek mine (San Benito County, CA, USA; Dunning et al. 2005), such as the deanesmithite (Roberts et al. 1993), edoylerite (Erd et al. 1993), hanawaltite (Roberts et al. 1996), clearcreekite (Roberts et al. 2001), tedhadleyite (Roberts et al. 2002), vasilyevite (Roberts et al. 2003) and aurivilliusite (Roberts et al. 2004).

Quartz/chalcedony and barite are the most common gangue minerals, followed by calcite/aragonite and kaolinite.

To summarising, cinnabar is mainly found in volcanic environments and hot springs deposits. It is often associated with stibnite and other $\mathrm{Hg}$-, $\mathrm{Sb}$ - and $\mathrm{Pb}$-based phases, as well as with gangue minerals as quartz, barite and calcite. In some archaeometric publications, we read that a cinnabar deposit's limited size may have prompted local populations to obtain supplies elsewhere. While this assumption is undoubtedly

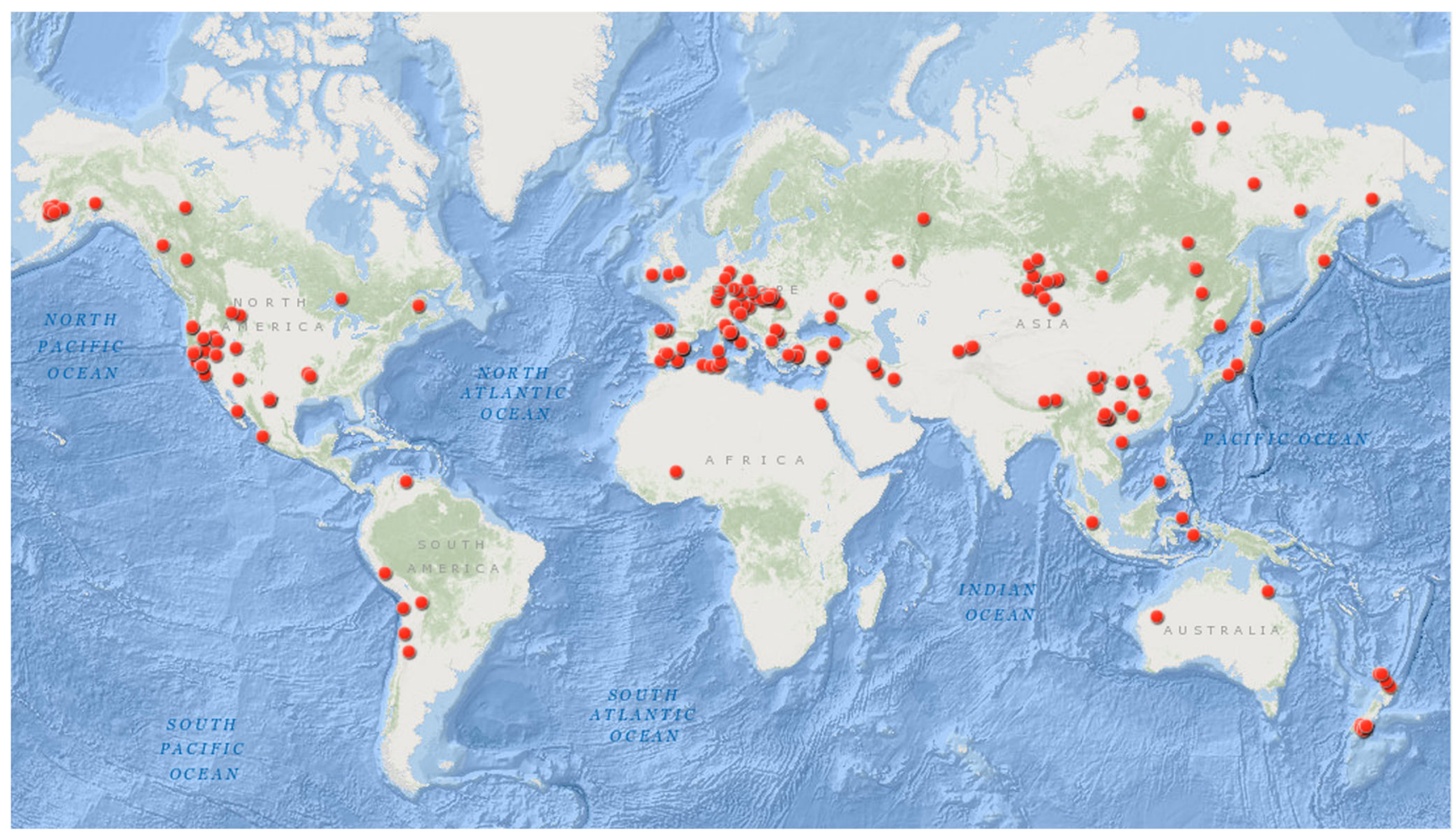

Fig. 5 Main cinnabar deposits. Data from Supplementary Table 1 
valid for industrial applications and thus related to the modern world, it seems less effective when applied to ancient civilizations.

\section{The multiple uses of cinnabar}

Cinnabar has been mainly used

- To paint human bones and offerings (funerary use). Based on the archaeometric evidence available so far, the first use of cinnabar appears related to funerary practices and ceremonial activities. To the best of my knowledge, the $9^{\text {th }}$ millennium BC painted plaster skull from Kfar HaHoresh in Israel (Goren et al. 2001) represents the oldest attestation of the use of cinnabar as a colouring pigment. Similar examples increase when dealing with the Late Neolithic and especially the Chalcolithic periods. The following section "Funerary use: esoteric power, social self-representation and archaeological evidence" is entirely dedicated to this topic.

- To decorate architectural structures and mobile objects (decorative use). Based on archaeometric data, the decoration of ceramic vessels, sculptures and cartonnages precedes that of wall paintings. Over time, the use of cinnabar to decorate structural elements increases considerably while its use for ceramics apparently disappears. This topic is discussed in the section "Decorative use: cinnabar over time and space".

- To write (ink in manuscripts). The use of cinnabar as ink is frequently attested, especially during the Middle Ages (see, e.g., Vlad et al. 2011; Serhrouchni et al. 2019; Safronov and Sozontov 2020). For the discussion of this topic, the reader is referred to Burgio (2021) in this TC.

- To enhance the reduction in lustre production, addressed in the section "Cinnabar for ceramic lustre".

- To colour red lacquers, addressed in the section "Cinnabar in lacquered objects".

- To serve for medicinal and cosmetic purposes (pharmacological use). Long-lasting use of mercury compounds is attested in ancient and oriental medicine, for example, in Indian Ayurveda (Murthy 1983), Oman (Hardy et al. 1995), Japan (Yamada et al. 1997), China (Anonymous 1967; Wu et al. 2002; Huang et al. 2007; Liu et al. 2008; Jain et al. 2019) and ancient Tunisia (Huq et al. 2006). The numerous therapeutic indications of cinnabar (esp. mercurial salts and other Hg-based compounds mixed with ointments) included fever, insomnia, lice, stoke, trauma, mouth ulcers and syphilis (Liu et al. 2018a). A further indication of the importance of mercury compounds in oriental tradition may be represented by the translation of the tanden (now better known as dantien) as the "cinnabar field", which is situated "two inches below the navel" (Ahn 2008) and represents the centre of gravity of the human body. The discussion of this topic is limited to some hints functional for the general discussion. For the details, the reader is referred to PérezArantegui (2021) in this TC.

Other "particular" findings and occurrences are also reported in the last section of this brief roundup on cinnabar occurrences (namely, "A (very) shortlist of other particular findings and occurrences of cinnabar").

An indispensable premise for the following sections concerns the bibliographic collection. Firstly, the publications collected are limited (almost always) to those in which the authors identified cinnabar through analytical techniques. Secondly, I am sure many publications were overlooked for various reasons ranging from accession difficulties to the language in which they were written. Consequently, the collection presented is not exhaustive but may offer a sufficiently articulated panorama of the state-of-the-art of the studies. The literature search was carried out by setting "cinnabar" as the key term in the search field (title and abstract) of Scopus. Eastaugh et al. (2004) and Siddall (2018) are also recommended on the uses of cinnabar and its characteristics.

\section{Funerary use: esoteric power, social self- representation and archaeological evidence}

The wide occurrence of Hg-based compounds in funerary contexts has long attracted the interest of researchers. Already in 1927, Peabody compiled a list of numerous occurrences in which "red paint" could be associated with the direct or indirect colouring (transfer from the burial) of the bones (Peabody 1927). He focused his review on ochres at a time when archaeometric analyses were not yet performed. Therefore, the achieved conclusion is also of interest for cinnabar: "We have seen that the use of color, especially red, in mortuary ceremonies is practically universal in time and space over the earth among prehistoric and primitive peoples". Peabody wondered, "what is the meaning of red?" and, after having warned the reader that "color symbolian is anything but obvious", came to the conclusion that "the most obvious suggestion of red is blood" (thesis argued and expanded in the following lines of his text).

Several authors have returned to this concept in the following years and the debate has opened numerous hypotheses and reconstructions. The common opinion is still focused on the correlation between red colour and blood and, consequently, the symbolism of life, death and sacrifice. In this regard, one of the anonymous reviewers rightly invites me to recall a concept 
dear to ancient philosophy, such as the "cosmic sympatheia". According to this Stoic thought, all beings on earth and in the heavens are closely connected ${ }^{3}$. However, other aspects such as the preservative properties of cinnabar, its use for body painting and tattooing and its magical aura are equally interesting and must be considered.

As for the conservative properties, cinnabar can delay the decomposition of the body thanks to its powerful bactericide and insecticide properties (Martín-Gil et al. 1995; CerviniSilva et al. 2013). This intent is usually highlighted by the location of burials in underground environments and/or far from sunlight and humidity. In this case, its use would have been functional rather than symbolic; consequently, determining whether cinnabar was applied soon after death or after decomposition of the soft tissues can undoubtedly be of crucial importance (see also Domingo Sanz and Chieli 2021 in this TC).

As for its use for body painting and tattooing, the discussion becomes more complicated and intriguing. In this case, the use of cinnabar may directly connect the deceased to her/ his life. Body painting could probably have had both an aesthetic and a social self-representation purpose during life. This practice would have followed a social dynamic that does not seem so distant from today's reality (with 60 million tattooed in Europe and more than $20 \%$ in the USA. Percentage considerably reduced in those countries like Japan where it is considered a social stigma - Harris Poll).

In this regard, the studies presented by Carter (2008) on EBI Cycladic society, Padilla et al. (2012) on argaric civilisation and Burger and Leikin (2018) on prehispanic Central Andean communities are exemplary. Carter (2008) connected the geographical and social expansion of the cultural and commercial exchanges of Early Bronze Age I Cycladic society (late $4^{\text {th }}-3^{\text {rd }}$ millennium BC) with a new way or a renewed interest in personal adornment (from tattooing to hair removal and jewellery). Quoting the authors, cinnabar "may have been reserved for special occasions (and people), limited body decoration and tattooing", thus "embodying" the ongoing political change. To support this intriguing hypothesis further, Carter also recalled the votive use testified by red-painted marble figurines and vessels found in Early Cycladic burials (references therein).

Padilla et al. (2012) observed that the diffusion of cinnabar in Argaric funerary contexts was more widespread among female individuals than in males and, therefore, deduce that cinnabar was linked to face and body makeup.

Burger and Leikin (2018) underlined that the prehispanic Central Andean communities used cinnabar for facial and

\footnotetext{
$\overline{3}$ The concept recurs in medical writings (e.g., Hippocrates, De alimento, 23.1) to indicate how soul and body or the different parts of the body are related to the body as a whole.
}

body paint and its use went far beyond a vain desire for beauty to become an "expression of social identity" (Burger and Leikin 2018).

Observing the use in life for both beautification and social self-representation, it follows that the use after death (for the painting of human bodies) may achieve multiple values, from the desire to preserve one's natural appearance for the afterlife world to the desire to externalise one's social rank also through one's own burial or even, more simply, to give the deceased the appearance of a leaving body for the benefit of the living.

Even the magical aura to which cinnabar was likely associated could have played a role in all this. Still, several distinctions would become necessary as it is not obvious to assign a unique meaning to a pigment that has gone through very different cultures and chronological periods. Finally, it is good to include among all these likely hypotheses the possibility that the bodies of the deceased and the offerings were sprinkled with cinnabar to keep thieves and profaners away. The poisonous nature of the pigment was already well known in ancient times. This aspect may have represented both an intended use and an added value of cinnabar compared to red ochre.

Other aspects concern analytic practice more closely, such as assessing whether mercury entered bones either biogenically or diagenetically. In the former case, mercury derives from direct exposure; while in the latter, the process involves a transfer from the soil. On this topic, the research conducted by (a) Emslie et al. $(2015,2019)$ on skeletal material from Middle and Late Neolithic and Early Bronze Age Iberian and Portuguese necropolis and (b) Cervini-Silva et al. (2013, 2018) on Mexican Red Queens and other funerary contexts must indeed be cited for both their intrinsic and methodological value.

As anticipated above, a significant body of literature exists on the contamination of land and rivers following mining activities and valuable information can also be drawn from these publications. In this regard, two case studies clearly explain how complicated or controversial it may be to correctly interpret the presence of mercury/cinnabar in archaeological sites. The first case regards the mobilisation of cinnabar during diagenesis. This naturally occurring phenomenon has been recognised by García-Alix et al. (2013) as the alteration process responsible for the red colour of Miocene fossil mammals (bones and teeth) found in the Otura section (Granada Basin, Spain).

The second case regards the black mercury alteration detected on the surface of numerous jades found in "high-grade" Chinese tombs. This alteration has been recognised as a human-related phenomenon by Bao et al. (2019), who found that the alteration was due to the fire ("Liaoji") ceremonial activity (burning oblations) during which the jade was placed over cinnabar. The latter turned into mercury vapour ( $>$ $800^{\circ} \mathrm{C}$ ) and thus caused the superficial alteration of jade. 
As for the occurrences of cinnabar in burial contexts, the attestations are many; however, the archaeological findings are not accompanied by archaeometric analyses in many cases. Therefore, it is not always possible to know whether it is ochre or cinnabar or a mixture of both or if there are associated aromatic compounds. Here, only a few verified examples are presented to show the spread of this practice broadly. The number of studies performed on this topic also appears unbalanced as most refer to Spanish, Portuguese and South American archaeological sites.

The occurrences in Spain are listed in Table 2 and shown in Fig. 6. Those reported in Meso- and South America (Belize, Chile, Guatemala, Honduras, Mexico and Peru) are provided in Table 3 and shown in Fig. 7.

In Meso- and South America, the occurrences are mainly concentrated in the Mayan territory and scholars partially agree in stating that cinnabar was used above all in the funerary contexts of the ruling elite (Schele and Mathews 1999; Vázquez de Ágredos Pascual 2007, 2018; Fitzsimmons 2009; Quintana et al. 2015). A comprehensive work on the use of cinnabar and other pigments for body paint is provided in the recent volume edited by Vázquez De Ágredos Pascual and Dupey García (2018), in particular, by Vázquez De Ágredos Pascual (2018) within the volume. The numerous contributing authors examined the phenomenon from all its points of view (material and cultural) and in the various social and cultural contexts of Mesoamerica, from pre-Columbian to modern times.

Apart from these two large areas that have returned most of the evidence (or in which the researchers carried out the highest number of archaeometric investigations), we must finally also remember the few occurrences around the Mediterranean basin:

- Israel - On the $9^{\text {th }}$ millennium BC (Pre-Pottery Neolithic B) plastered skull of the KHH-Homo 8 from Kfar HaHoresh (Goren et al. 2001; Goring-Morris and Horwitz 2007 for an insight on the site);

- Syria - On the painted Pre-Pottery Neolithic B skull inv. No. 73.2772 found at Tell Abu Hureyra (Trench A, level 212) (Molleson et al. 1992);

- Turkey - In the $8^{\text {th }}$ millennium BC phase of Çatal Hüyük, where cinnabar was used to paint the skull of a "woman with a necklace of sliced dentalium beads" and for wall paintings (Mellaart 1967);

- Russia - In the $34^{\text {th }}-30^{\text {th }}$ century BC burial 1 (individual 1) at the Maikop-Novosvobodnaya settlement of Chekon2 (Taman Peninsula), cinnabar was found in the fragments of the upper cranial vault (Korenevskiy et al. 2015).

To conclude, it is also worth underlining that the use of cinnabar in burials is also attested in prehistoric and historical China and Japan (Bao et al. 2019; Liu 2004).
In China, a comprehensive study on textiles and cinnabar decorated leather objects $\left(1^{\text {st }}\right.$ millennium $\mathrm{BC}-1^{\text {st }} / 3^{\text {rd }}$ century $\mathrm{AD})$ associated with mummies from the Xinjiang Uyghur Autonomous Region was performed by Kramell et al. (2016). The leather scabbard of a bronze sword covered by cinnabar was also found in the tomb M4 of the Qiaojiayuan site (Yun country, Hubei province; Luo et al. 2011).

Another example is represented by the cinnabar powder covering the surface of a set of the mid- $11^{\text {th }}-$ mid- $-9^{\text {th }}$ century $\mathrm{BC}$ jade artefacts related to burial ceremonies from a tomb of the Ying State's Cemetery (Pingdingshan, Henan; Zhao et al. 2014). Particular use is also testified by the Shang epoch (1766-1122 BC) oracle bones (turtles plastrons and bovine scapulas used in divination) painted with cinnabar from Yin Hsü (Anyang, Honan; Benedetti-Pichler 1937).

In Japan, the funerary use of cinnabar lasted from the midYayoi period till the late Kofun period $\left(4^{\text {th }}\right.$ century $\mathrm{BC}-6^{\text {th }}$ century $\mathrm{AD}$ ). It was aimed at decorating (coffins), preserving (antisepsis) and staining (textiles), as well as having a ritual function and representing a symbol of power (Kawano et al. 2014). An example is provided by the Takamatsuzuka tumulus $\left(7^{\text {th }}-8^{\text {th }}\right.$ centuries) at Asuka (Nara prefecture, Kinki region), where cinnabar was identified in the murals (Kitada et al. 2015).

As a very last example, it is also worth mentioning the cinnabar painted skull found in Idaho that, dated to 600-700 years BP, was assessed to belong to one of four major Native American mitochondrial DNA lineages (Watkins et al. 2017).

\section{Decorative use: cinnabar over time and space}

Cinnabar was used for the decoration of mobile objects and probably later for the decoration of architectural surfaces. This trend seems valid both for the Mediterranean world and the Near East as well as for Meso- and South America. The most ancient attestations include mobile objects decorated with cinnabar found worldwide in funerary, religious and, to a lesser extent, residential contexts.

In South America, to give a representative example, the enormous number of 1500-1200 BC objects related to funerary practices and daily life found at Gramalote in Peru were painted with cinnabar or hematite or a mixture of both (Prieto et al. 2016).

In the Mediterranean area, particularly ancient attestations are sporadic. The likely oldest attestation on wall paintings dates to the level VIII (6700 cal. BC) onwards of the archaeological site of Çatalhöyük in Turkey (Çamurcuoğlu 2015). Out of a total of fifty-nine red pigment samples taken from wall paintings and burial contexts, the author found cinnabar in only 3 of them. Cinnabar was identified by Raman spectroscopy, either used alone or in mixture with red ochre, and was tentatively traced back to the mercury deposits "in the southwest and north of Konya region as well as around Niğde in the east". Mellaart (1967) hypothesised a provenance 


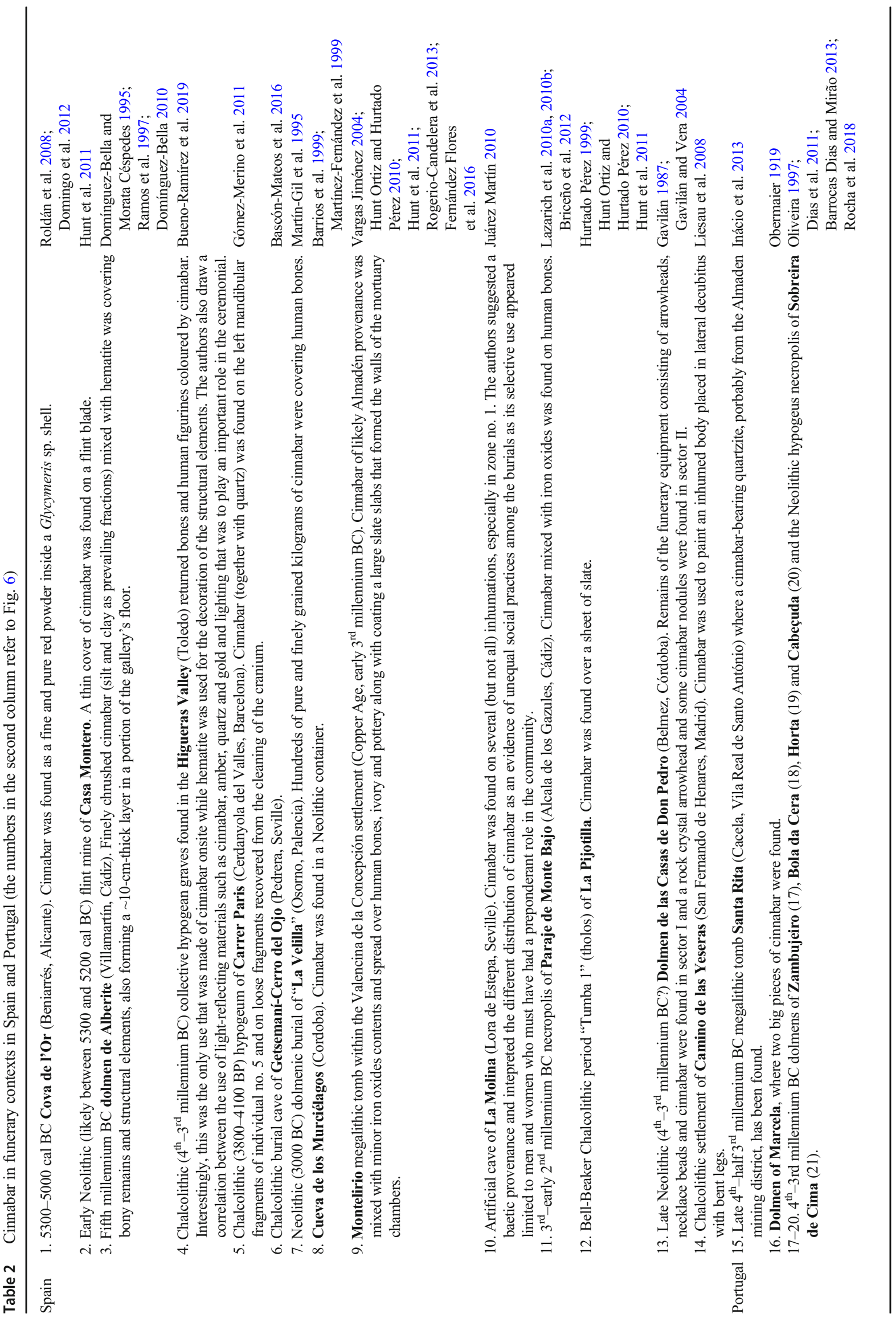




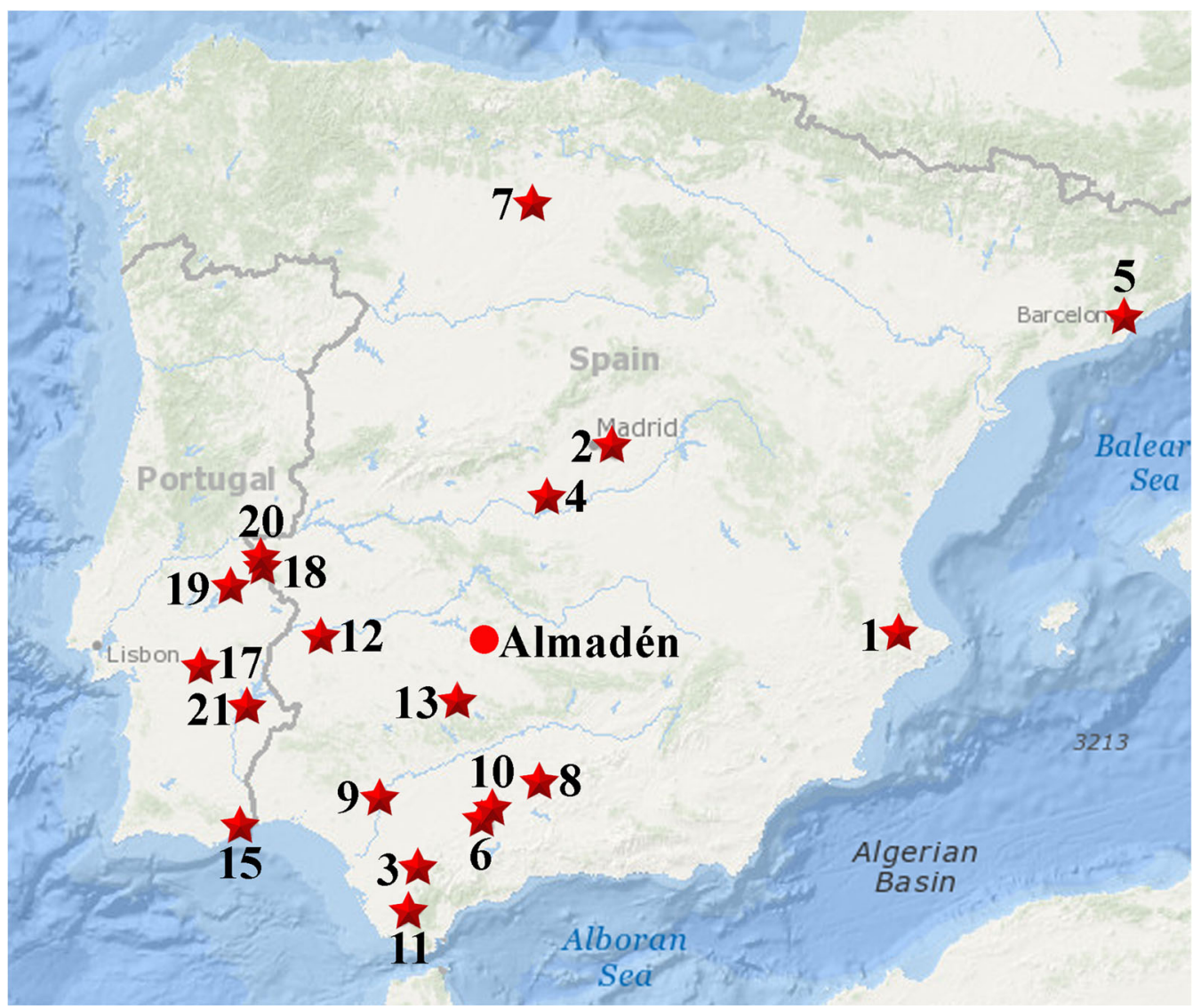

Fig. 6 Cinnabar in funerary contexts - Spain and Portugal. The geographic location of the sites listed in Table 2

from the Sizma deposits but no supporting archaeometric investigations are available in this regard (Doherty 2011). In any case, the Sizma deposit (not reported in the Mindat.org database) is about $60 \mathrm{~km}$ away as the crow flies from Çatalhöyük and it is, therefore, the closest deposit known so far (Fig. 8).

The Vinča settlement provides another example. Cinnabar appeared ubiquitous in layers dated from the mid- $6^{\text {th }}$ to the mid- $5^{\text {th }}$ millennium BC (Vasić $1932-1936$, I as quoted by Gajić-Kvaščev et al. 2012). A cinnabar powder was also stored inside Neolithic pottery (inventory no. C-417, dated to 5200-4200 BC) (Mioč et al. 2004). Similarly, at Pločnik, a Gradac sub-phase ceramic vessel (end of the $6^{\text {th }}$-early $5^{\text {th }}$ millennium BC) was found to contain a cinnabar powder (cinnabar mixed with quartz, illite, kaolinite and other clay minerals); moreover, cinnabar was also used to decorate figurines (Gajić-Kvaščev et al. 2012).

In the $1^{\text {st }}$ millennium $\mathrm{BC}$, ancient examples (based on archaeometric evidence) are present on ceramic pottery and sculptures from Spain, Italy and Greece. As for ceramic decoration, it is possible to mention:

(a) the $6^{\text {th }}-5^{\text {th }}$ century BC small vessel found in tomb no. 233 (burial mound $\mathrm{H}$ ) of the cemetery of La Noria (Fuente de Piedra, Málaga; Tuñón et al. 2016); (b) the $5^{\text {th }}$ millennium BC Serra Alto pottery found in the Grotta dei Cervi (Porto Badisco, southern Italy; Quarta et al. 2018); and

(c) the $4^{\text {th }}-3^{\text {rd }}$ century $\mathrm{BC}$ ceramic vessels found in the Iberian cemetery of Tutugi (Galera, Granada, Spain; Sánchez et al. 2012).

Regarding sculpture, the Early Cycladic II (3100-2400 BC) marble figurines (Hendrix 1998; Carter 2008) provide a representative example.

Moving forward in time, cinnabar has been frequently used for the decoration of numerous Egyptian coffins. The cartonnages dated between the $21^{\text {st }}$ and the $25^{\text {th }}$ Dynasty (1070-525 BC) show a somewhat standardised palette with slight variations. Six basic pigments are constantly found: cinnabar, Egyptian blue, yellow and red ochres, orpiment and carbon black. Other copper-based pigments such as atacamite have been found less frequently; conversely, the presence of azurite, Prussian blue and lead white are generally attributed to retouches and restorations of a later period. The study performed by Gard et al. (2020a, 2020b) on a Ptolemaic cartonnage (305-30 BC) deserves a special mention because - besides the typical pigments - pararealgar, bonazziite and/or alacránite, uzonite and Egyptian green $\left((\mathrm{Cu}, \mathrm{Ca}) \mathrm{SiO}_{3}\right)$ were also found (for the As-containing phases 


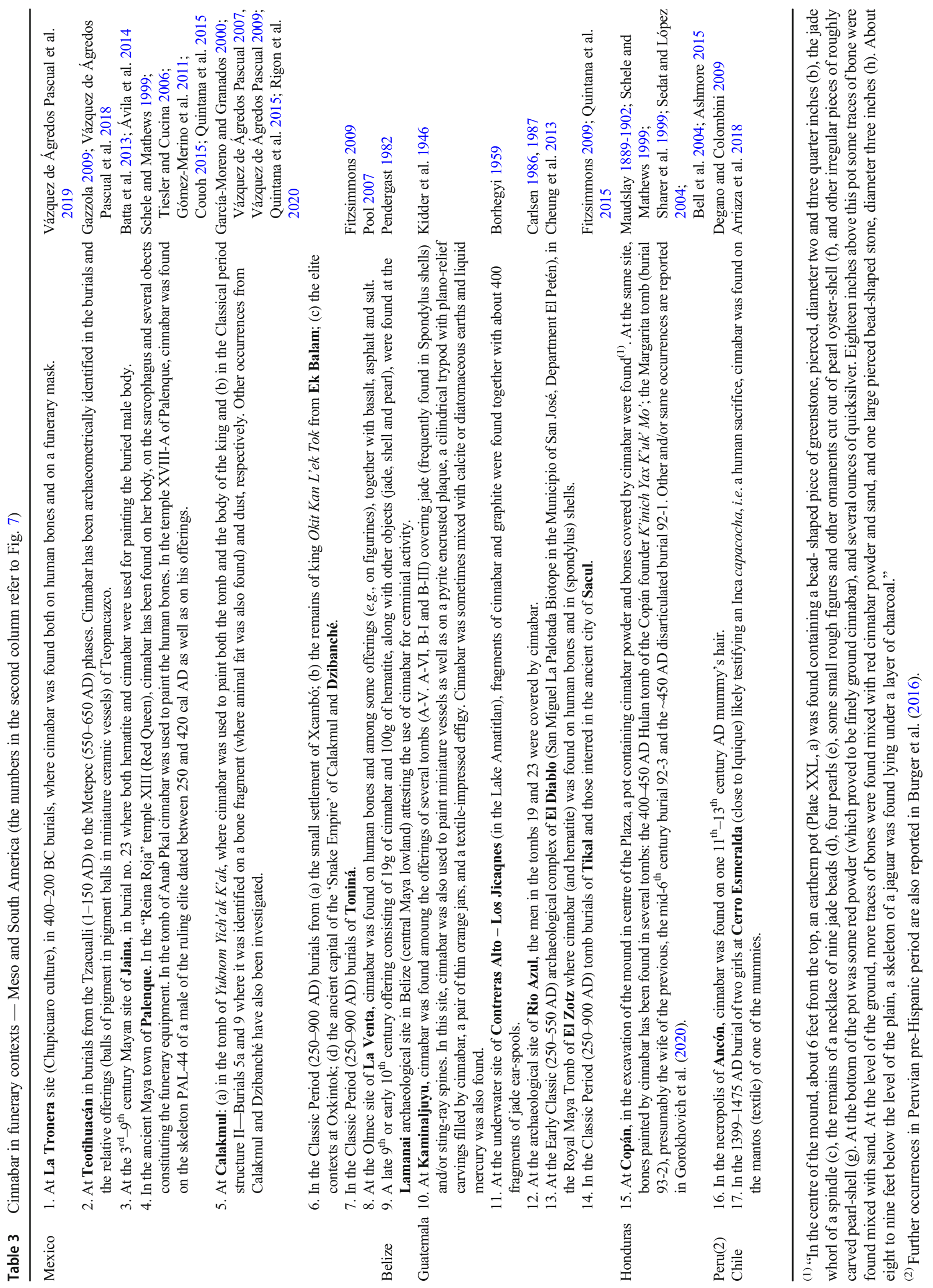


and the Egyptian blue and green pigments see Gliozzo and Burgio 2021 and Švarcová et al. 2021, respectively in this $\mathrm{TC})$.

Going further in time, the evidence of pictorial decorations on architectural elements begins to take on consistency. The fragments of decorated walls, floors and columns recovered in Persepolis and Pasargadae $\left(6^{\text {th }}-4^{\text {th }}\right.$ century BC), the wall paintings of the Tomb IV in Phoinikas in Greece (end of $5^{\text {th }}-4^{\text {th }}$ century BC; Avlonitou 2016), the second tomb of Vergina in Greece ( $4^{\text {th }}$ century BC; Filippakis et al. 1979), the Etruscan 'Tomba dell'Orco' at Tarquinia in central Italy $\left(4^{\text {th }}\right.$ century BC; Sodo et al. 2008) and, probably also the first Pompeian style House in Pella (400-168 BC; Calamiotou et al. 1983) are among the earliest attestations. However, it will be necessary to wait until the $2^{\text {nd }}$ and $1^{\text {st }}$ century $\mathrm{BC}$ before finding cinnabar constantly used to decorate architectural elements (based on sure evidence verified through archaeometric analyses).

Between the $3^{\text {rd }}$ and $1^{\text {st }}$ centuries, verified evidence testifies the use of cinnabar on both mobile objects and wall paintings in Europe and Asia. In the first case, some examples are found:

- in China, on the polychrome terracotta soldiers found in the Tomb of Jing Di Emperor - Xi'an (221-140 BC; Chiavari and Mazzeo 1999), in the Royal tomb in the Qingzhou County (Shandong; Wei et al. 2012) and on the Jian $\mathrm{Hu}$ polychrome terra-cotta jar found at the
Xi'an Airport (206 BC-23 AD; Chiavari and Mazzeo 1999);

- in Europe, on the terracotta figurines found in Hellenistic tombs at Thessaloniki and Demetrias (Greece, $3^{\text {rd }}-2^{\text {nd }}$ century BC; Fostiridou et al. 2016; Tsatsouli and Nikolaou 2017).

Testimonies on wall paintings are instead found:

- in Italy, in the House of the Golden Bracelet at Pompeii and the villa of Papyri at Herculaneum $\left(2^{\text {nd }}\right.$ century BC; Durán et al. 2010a, 2010b), in the painting layer on mortar under the mosaics of a house located under the church of St. Susanna in Roma $\left(2^{\text {nd }}-1^{\text {st }}\right.$ century BC; Boschetti et al. 2008), and in wall paintings found at the archaeological sites of Torre (Pordenone), Crosada (Trieste) and Montegrotto (Padova) $\left(1^{\text {st }}\right.$ century BC; Mazzocchin et al. 2004);

- in Spain, in the Roman necropolis of Camino Viejo de Almodóvar (Córdoba, $1^{\text {st }}$ century BC; Cerrato et al. 2020) and in the Roman villa of Baños de Valdearados (Burgos, $1^{\text {st }}$ century $\mathrm{BC}-1^{\text {st }}$ century $\mathrm{AD}$; Villar and Edwards 2005);

- in Palestine, in the Palace of King Herod the Great at Jericho and Massada $\left(1^{\text {st }}\right.$ century BC; Edwards et al. 1999b; Porat and Ilani 1998).

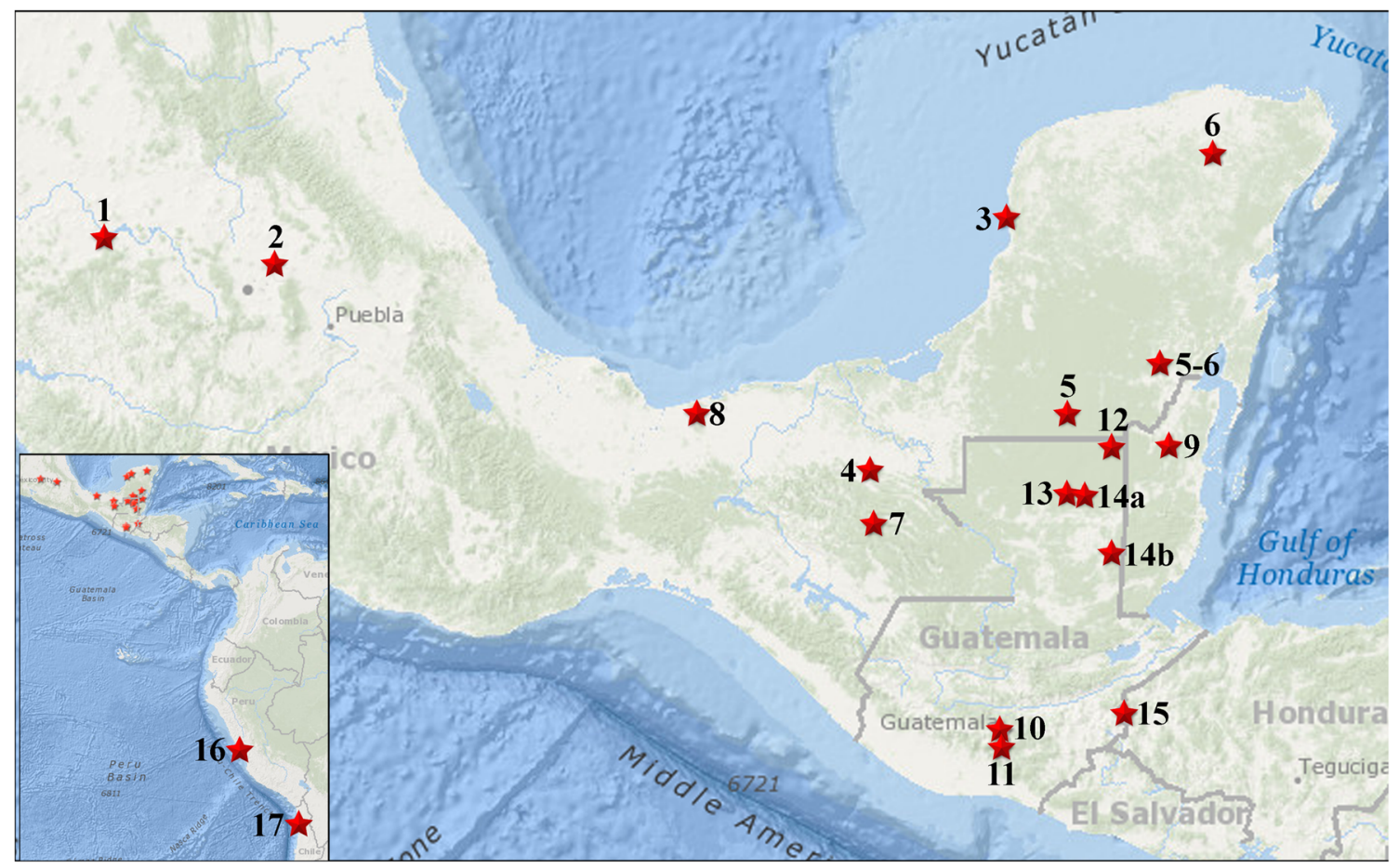

Fig. 7 Cinnabar in funerary contexts - Meso- and South America. The geographic location of the sites listed in Table 3. Sites $14 \mathrm{a}$ and $14 \mathrm{~b}$ correspond to Tikal and Sacul, respectively. Site 5-6 indicates the location of Dzibanché 


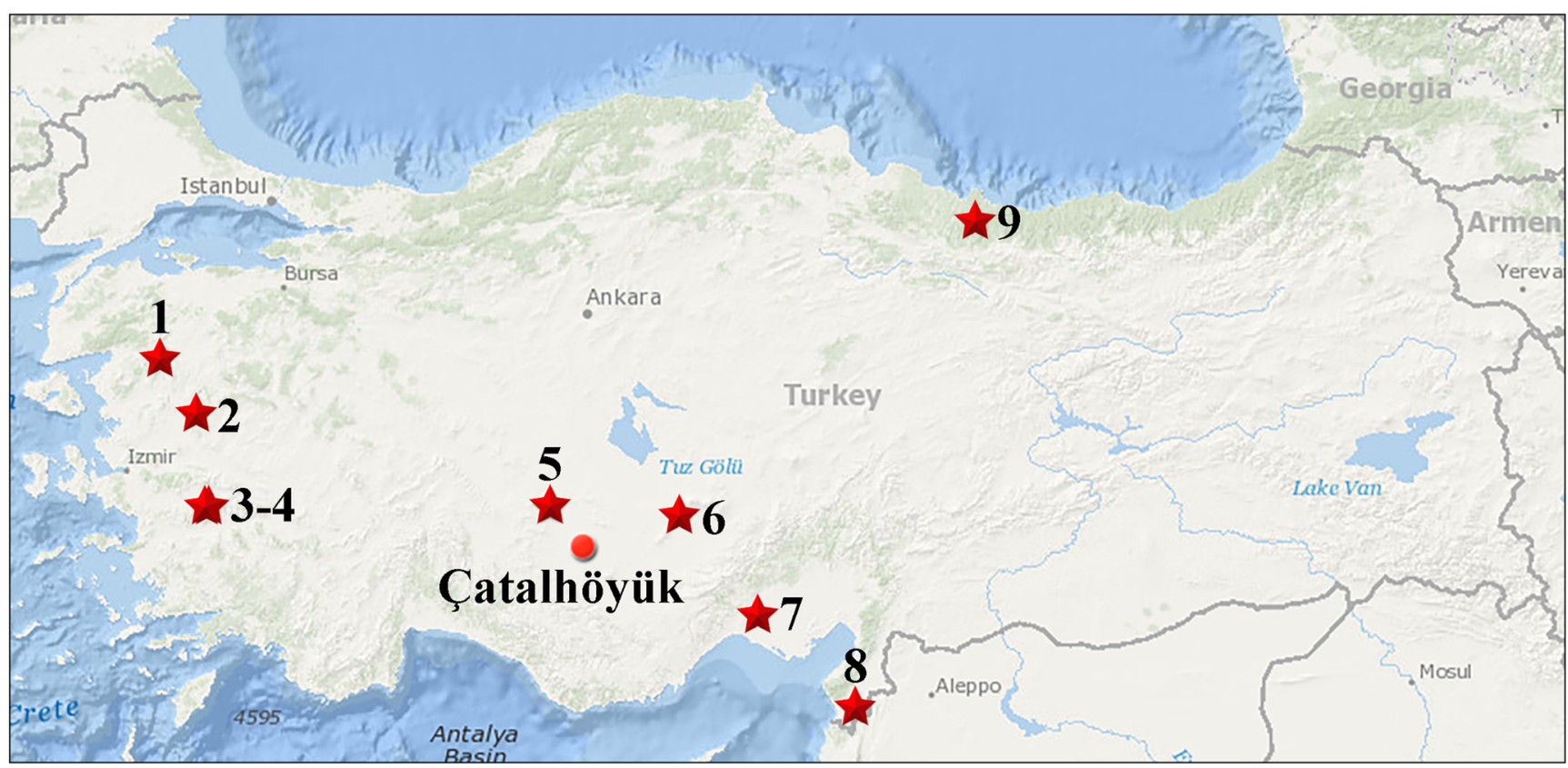

Fig. 8 Cinnabar deposits and occurrences in Turkey. (1) Kuçukyenice, Ivrindi, Balikesir, Marmara; (2) Baglar Hill, Mumcu, Balikesir, Marmara; (3) Emirli Sb-Au deposit, Ödemiș, Izmir; (4) Halıköy Hg deposit, Ödemiş, Izmir; (5) Sizma, Selçuklu, Konya; (6) Rasih-thsan occurrence,
Niğde; (7) Madsan Sb deposit, Çamardı, Niğde; (8) Kisecik Au deposit, Antakya, Hatay; (9) Akoluk, Ulubey, Ordu. Data from Mindat.org except for Sizma. The archaeological site of Çatalhöyük is indicated with the red filled circle
The numerous bowls containing powdered pigments found in Pompeii and analysed by Aliatis et al. (2010) must also be referred to an unspecified time before $79 \mathrm{AD}$.

Up to this period, the association with inorganic pigments is limited to carbon black and sporadically to madder lake while animal glue prevails among the binders. Other organic pigments such as indigo and other binders such as oils will be more frequent in the following centuries.

Between the $1^{\text {st }}$ and $3^{\text {rd }}$ centuries, the testimonies relating to the wall paintings gradually increase. However, most of the investigations are relevant to Italian archaeological areas:

- Domus Aurea, Rome (64 AD; Clementi et al. 2011);

- Domus at Liternum ( $1^{\text {st }}$ century; Corso et al. 2012);

- Domus of Octavius Quartio, Pompei ( $1^{\text {st }}$ century; Germinario et al. 2018);

- Tomba dei Pesci e delle Spighe, necropolis of Tuvixeddu, Cagliari ( $1^{\text {st }}$ century; Solla et al. 2015);

- House of Diana, Cosa-Ansedonia (after 80 AD; Damiani et al. 2003; Fig. 9A-B);

- Domus below the Basilica of SS. John and Paul on the Caelian Hill, Rome (end of $1^{\text {st }}-4^{\text {th }}$ centuries; Fermo et al. 2013);

- Roman villa in Vicenza (Mazzocchin et al. 2003);

- Tomb 75 - Necropolis at Tenuta Boccone D'Aste, Roma (2nd century; Aurisicchio et al. 2002);

- Thermae of Iulia Concordia, Venezia (second half of the $2^{\text {nd }}$ century; Mazzocchin et al. 2010).
Other case studies regard wall paintings found in Morocco (Thamusida, $1^{\text {st }}-3^{\text {rd }}$ centuries by Gliozzo et al. 2012), Switzerland (Gallo-Roman villa at Dietikon, $1^{\text {st }}-3^{\text {rd }}$ centuries by Béarat 1996) and Turkey (Sinop Balatlar Church Complex, $2^{\text {nd }}-4^{\text {th }}$ centuries, by Bakiler et al. 2016).

In Egypt, most findings relate to paintings on wood. In this regard, famous examples are represented by the Roman mummy portraits of approximately the $2^{\text {nd }}$ century found at Tebtunis and investigated by Salvant et al. (2018).

From about the $4^{\text {th }}$ century up to the Middle Ages, the evidence relating to manuscripts (see Burgio 2021 in this TC), scroll painting and, overall, to painting on parchment, paper and various types of textiles is added to mobile objects (Table 4). In this regard, it is worth adding that, in manuscripts, cinnabar was used both for illuminations and as ink (see also above).

Among mobile objects, I have not found any evidence of possible use in ceramic decoration. On the contrary, I have collected numerous attestations relating to the sculptural decoration and, above all for the clay or sandstone sculptures of Buddha present in many Chinese regions such as Sichuan (618-907 - Caves no. 512 and 689, Guangyuan Thousand-Buddha Grotto; He et al. 2012), Shaanxi ( $11^{\text {th }}$ century - Main cave, Zhongshan Grottoes; Egel and Simon 2013; $\geq 1016$ AD - Jizo Hall, Chongqing Temple; Wang et al. 2014), Datong (1038 AD - Hua Yan Temple; Wang et al. 2020) and 
Chongqing (late $12^{\text {th }}-$ mid $13^{\text {th }}$ centuries, retouched until the 1850s - Dazu Rock Carvings; Li et al. 2020b).

Among proper mobile objects, there are also three uncommon finds. In chronological order, the first is represented by the early $11^{\text {th }}$-century beeswax seals from the documents of the Order of St. John of Jerusalem, sc. Knights of Malta (National Library of Malta, Valetta) investigated by Szczepanowska and Fitzhugh (1999). The second concerns the late $12^{\text {th }}$-early $13^{\text {th }}$ century Lewis chessmen in ivory preserved in the Collection of the National Museums Scotland and investigated by Tate et al. (2012). The third ones are the $14^{\text {th }}-15^{\text {th }}$ century alabaster panels produced in the Midlands (UK) and analysed by Mounier et al. (2020) and Pereira-Pardo et al. (2019).

As far as architectural elements are concerned, the attestations are many and geographically widely distributed. The list provided in Table 5 shows that (a) the a fresco and the a secco techniques continue to be attested, although the authors frequently specify that some pigments as cinnabar were applied over an ochre layer (Fig. 9C-D) or on dried lime; (b) the evidence is not chronologically continuous. The gaps recorded for the $5^{\text {th }}$ and $8^{\text {th }}-9^{\text {th }}$ centuries may be due to the lack of archaeometric studies on wall paintings of that time, or a lack in the bibliographic collection, or an actual decrease in the use of cinnabar in these periods.

Another interesting aspect is that at least until the $4^{\text {th }}$ century, the use of cinnabar remained for the realisation of mosaics' sinopias. In fact, to the $2^{\text {nd }}-1^{\text {st }}$ century BC examples found in the house below the Santa Susanna church in Rome (Boschetti et al. 2008), it is possible to add the $4{ }^{\text {th }}$-century sinopia found under the mosaic of the villa of Lod in Israel (Piovesan et al. 2014; wall paintings of the villa of Lod in Piovesan et al. 2016).
Lastly, it is worth mentioning the copious use of cinnabar for the decoration of icons. The examples are concentrated between the $13^{\text {th }}$ and $19^{\text {th }}$ centuries and are almost always prepared with the tempera technique (Table 6).

As for Meso and South America, apart from the wide use of cinnabar to paint human bones and funerary/ceremonial practices, the attestations regarding the decoration of mobile objects and wall paintings gradually increase. In the first case, the objects are still primarily linked to the funerary sphere; in the second case, painted walls are concentrated in tombs and monumental complexes. The documentation appears still scarce regarding residential buildings.

To give just some examples, evidence of the use of cinnabar for the decoration of mobile objects has been provided for:

- a funerary golden mask on tumbaga belonging to the Sicán culture (750-1375 AD) and preserved at the Museum of Sicán at Ferrañafe in Peru (Cesareo et al. 2010);

- a Red Jaguar Throne sculpture (800-1250 AD) found in 1936 in the upper part of the sub-structure of the Kukulkan's pyramid at of Chichén Itzá, Yucatán, Mexico (Juárez-Rodríguez et al. 2018);

- the 500-1000 AD wooden Pachacamac Idol (Sepúlveda et al. 2020).

As for wall paintings, based on Magaloni et al. (1993), Magaloni 1998and Vázquez de Ágredos Pascual (2007), "the earliest use of cinnabar in Mayan wall painting is documented at Bonampak, around the mid Late Classical period" (i.e. 250 and $900 \mathrm{AD}$ ). However, further research may lead to identifying this pigment in more ancient Classic contexts (i.e. Early Classic or Late Preclassic).

The testimonies are limited in number for the most ancient periods while they increase in the following centuries. Apart
Fig. 9 The visible difference between $\mathbf{A}$ cinnabar and $\mathbf{B}$ red ochre in two fragments from the House of Diana at Cosa. C-D SEM-BSE image: it is possible to observe an upper layer of cinnabar (white) overlaying an irregular layer made of yellow ochre (light grey) above the plaster (contrast enhanced to emphasise layering)
A
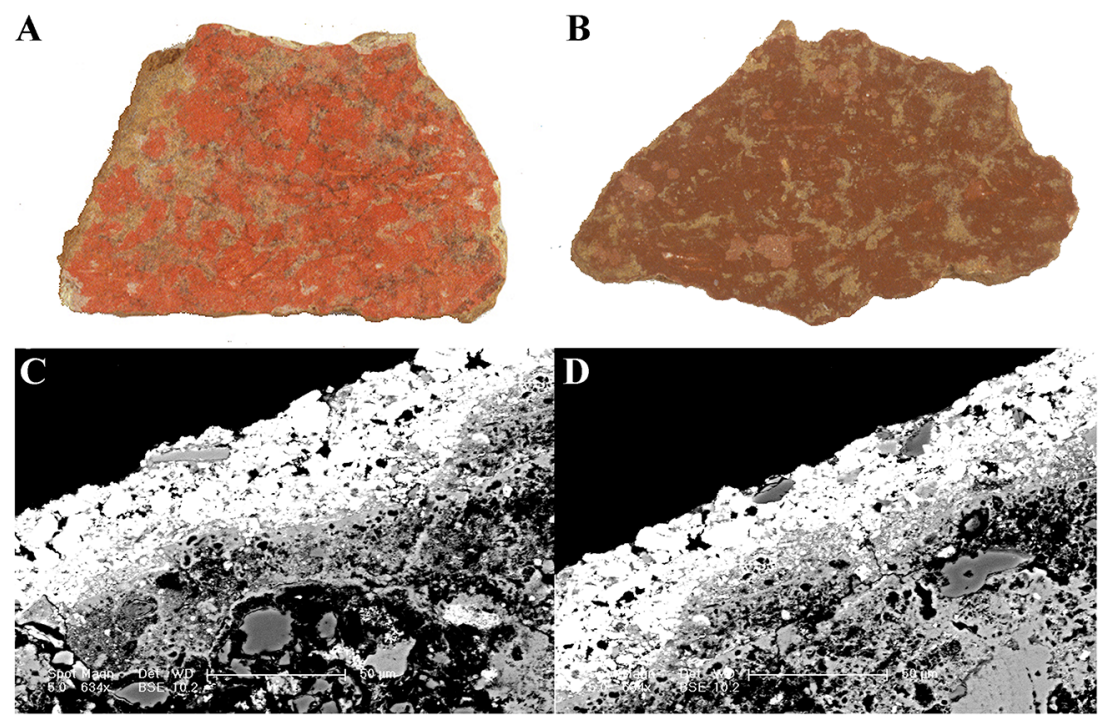
Table 4 Cinnabar on parchment, paper and textiles (some examples). Conservation sites in square brackets

Artwork Chronology Reference

Codex Eusebii Evangeliorum (A Codex) by Saint Eusebius, first Bishop of Vercelli (?) [Cathedral Treasure 345-371 Museum of Vercelli, Italy]

Vienna Dioskurides (Codex Vindobonensis Med. gr. 1) — Copy of the Herbarium of the Greek doctor Pedanios Dioskurides (parchment) — Written in Constantinople [Austrian National Library at Vienna]

Mahamayuri Vidyarajni Sutra (bamboo and bark/textile) found in the Nanmen Buddhist pagoda, Anhui, China

Tours Gospel, "Evangelia Quatuor" [British Library (Add. MS. 11848), UK]

Koran (parchment MEK-MS-7LP and MEK-MS-6LP) [Cultural Complex Lamnouni of Meknes, Morocco]

Beato (parchment/vellum) [Monastery of Santo Domingo de Silos, Burgos, Spain]

Commentaries of the Apocalypse (parchment/vellum) [Santa María la Real Monastery in Nájera (AMS-N1), $10^{\text {th }}$ Spain]

Found near Dunhuang, Khara-hoto or Tujuk, China [Oriental Institute of the Russian Academy of Sciences in pre-10 St Petersburg, Russia]

Arabic manuscripts (paper) [Archive of the Sacromonte Abbey in Granada, Spain]

Medieval miniatures on paper of Saint Matthew and an eagle (symbolic of the evangelist John the Theologian) $12^{\text {th }}$ [Holy Monastery of Simonopetra on Mount Athos, Greece]

Folios on The Book of Curiosities of the Sciences and Marvels for the Eyes [The Bodleian Library, Oxford, UK] Early $13^{\text {th }}$

Byzantine/Syriac Gospel [British Library Oriental and India Office Collection, UK]

Diplomatic documents of the Ottoman Empire (parchment/paper) [Ottoman Archives in Istanbul, Turkey]

Manuscript D.I.21 better known as Messale Rosselli by different artists. Made in Avignon for the Aragonese Cardinal Nicolas Rossell (1314-1362) [Biblioteca Nazionale Universitaria in Torino, Italy]

Lubab al-Ta'wilfi ma'ani al-tanzil by Al-Jazin

Book 814 (1R, 5V, 11R, 26V) by Evangelista della Croce Paper (parchment) [Old library of the Certosa di Pavia]

Book 814 (16R, 21V; parchment) by Girolamo dai Libri [Old library of the Certosa di Pavia]

Book 818 (1R; parchment) by Benedetto da Bergamo [Old library of the Certosa di Pavia]

Book 819 (35R; parchment) by Benedetto da Bergamo [Old library of the Certosa di Pavia]

Book 820 (1R; parchment) by Benedetto da Bergamo [Old library of the Certosa di Pavia]

Book 821 (15V, 25R; parchment) by Guarnerio Beretta [Old library of the Certosa di Pavia]

Book 822 (1R; parchment) by Evangelista della Croce [Old library of the Certosa di Pavia]

Book 823 (21R, 39R; parchment) by Guarnerio Beretta [Old library of the Certosa di Pavia]

Illuminated manuscript (parchment) [State Archives of Milan, Italy]

The Cofre no. 31 [Library of the National Palace of Mafra, Portugal]

King George III copy of the Gutenberg Bible [British Library, UK]

Privilegio rodado by King Enrique IV (parchment) [Archive of the Royal Chancellery in Granada, Spain]

Paper currencies Da ming bao chao, da qing bao chao, hu bu guan piao - China

Book of Tides (illuminated parchment) [Private collection]

A choir book (MAR-97, 98) and a liturgical book (MAR-68) [Collection of Canon Jean Marcadé donated to the French State in 1947, France]

Illuminated foral charter of Setubal (parchment) [Portuguese National Archive, Portugal]

Persian Herati lacquered manuscript (paper). Produced in the city of Herât, Afghanistan

Manueline foral charter of Sintra (parchment). Attributed by D. Manuel I of Portugal to the village of Sintra, Portugal

Coaching inn books (parchment/vellum) [Monastery of Santo Domingo de Silos, Burgos, Spain]

Printed book Osorio (paper) [Museum of Slavonija, Osijek, Croatia]

Map of Vicenza (paper), Italy - Atlas Major

Lengjinjian (gold-dusted) paper [China Printing Museum, Beijing, China]

Japanese painting on paper (horizontal scroll) - Bamo Dōi-zu attributed to Kanō Sansetsu (1589-1651).

[Stibbert Museum in Florence, Italy]

Javanese and Thai manuscripts [British Library Oriental Department]
Aceto et al. 2008

Aceto et al. 2012 $6^{\text {th }}$

$618-627$

Liu et al. 2019

Clark and Van Der Weerd 2004

Oubelkacem et al. 2021

$0^{\text {th }}-11^{\text {th }}$

Carter et al. 2016

Carter et al. 2016

Clark et al. 1997 $\mathrm{AD}$ $11^{\text {th }}-17^{\text {th }}$

Espejo Arias et al. 2008

Daniilia and Andrikopoulos 2007

Chaplin et al. 2006

1216-1220

Clark and Gibbs 1997, 1998

$13^{\text {th }}-20^{\text {th }} \quad$ Kantoglu et al. 2018

Mid-14 ${ }^{\text {th }} \quad$ Calà et al. 2019

$14^{\text {th }}$

Durán et al. 2009

$15^{\text {th }}$

$15^{\text {th }}$

$15^{\text {th }}$

$15^{\text {th }}$

$15^{\text {th }}$

$15^{\text {th }}$

$15^{\text {th }}$

$15^{\text {th }}$

$1450 \mathrm{~s}$

$15^{\text {th }}$

Mid-15 ${ }^{\text {th }}$

$15^{\text {th }}$

$15^{\text {th }}, 19^{\text {th }}$

$15^{\text {th }} / 16^{\text {th }}$

Bonizzoni et al. 2016

Bonizzoni et al. 2016

Bonizzoni et al. 2016

Bonizzoni et al. 2016

Bonizzoni et al. 2016

Bonizzoni et al. 2016

Bonizzoni et al. 2016

Bonizzoni et al. 2016

Bruni et al. 1999

Carvalho et al. 2018

Chaplin et al. 2005

Durán et al. 2014

Shi and Li 2013

Vanmeert et al. 2018

1520-1530 Mounier et al. 2016

1515

Guerra et al. 2016

1530

Hayez et al. 2004

Manso et al. 2013

$16^{\text {th }}-18^{\text {th }} \quad$ Carter et al. 2016

$16^{\text {th }}-19^{\text {th }} \quad$ Lukačević et al. 2013

1640

Castro et al. 2008

1662-1722 Li et al. 2020c

$17^{\text {th }}$

Quattrini et al. 2014

ca. $1738 \quad$ Burgio et al. 1999 
Table 4 (continued)

\begin{tabular}{|c|c|c|}
\hline Artwork & Chronology & Reference \\
\hline $\begin{array}{l}\text { Portrait of Bazalibudala Arhat (woven silk net and paper) by Ding Guanpeng [Palace Museum, Beijing, } \\
\text { China] }\end{array}$ & 1756 & Li et al. $2020 \mathrm{a}$ \\
\hline Chinese scroll paintings - Portrait of Bazalibudala Arhat by Ding Guanpeng [China] & 1756 & Li et al. $2020 \mathrm{~d}$ \\
\hline $\begin{array}{l}\text { Volume Ornitologia dell'Europa meridionale by Clemente and Rosalba Bernini. Printed in Parma. [Biblioteca } \\
\text { Palatina at Parma, Italy] }\end{array}$ & $1772-1793$ & Zannini et al. 2012 \\
\hline $\begin{array}{l}\text { Volume Beytraz zur Naturgeschichte der Vogel by Joachim Johann Nepomuk Spalowsky. Printed in Vienna } \\
\text { [Biblioteca Palatina at Parma, Italy] }\end{array}$ & $1790-1795$ & Zannini et al. 2012 \\
\hline Cover of a cantoral book (parchment/vellum) [Monastery of Santo Domingo de Silos, Burgos, Spain] & $18^{\text {th }}$ & Carter et al. 2016 \\
\hline $\begin{array}{l}\text { Drawings and sketches by Szymon Czechowicz (1689-1775) [Jagiellonian University Museum, Krakow; } \\
\text { National Museums in Krakow and Warsaw, Poland] }\end{array}$ & $18^{\text {th }}$ & $\begin{array}{l}\text { Doleżyńska-Sewerniak } \\
\text { et al. } 2020\end{array}$ \\
\hline Thangkas (cotton cloth) likely from Tibet [private collection] & $18^{\text {th }}(?)$ & Brocchieri et al. 2020 \\
\hline Palm leaf manuscript from India & $18^{\text {th }}-19^{\text {th }}$ & Singh and Sharma 2020 \\
\hline
\end{tabular}

from the previously mentioned findings of Bonampak, the testimonies mainly regard the following sites:

- Teotihuacán, Mexico - Flourished between the $1^{\text {st }}$ and $6^{\text {th }}$ century, returned several occurrences: (a) the altar stone from the Conjunto Xolalpan (not analysed in Linné 1942); (b) the mural painting from the Calzada de Los Muertos analysed by Torres Montes (1972); (c) the structure $52 \mathrm{~F}$ in the Complejo Calle de Los Muertos analysed by SEM in Gazzola (2009); (d) the Xalla building, analysed but doubtfully in López Puértolas et al. (2019); and (e) the Temple of the Feathered Seashells and Quetzalpapalotl Palace analysed by Argote et al. (2020);

- Monte Albán, Oaxaca, Mexico - In the Late Classic period (790-792 AD) tombs 104 and 105 (Magaloni 1998);

- Tajín, in southern Mexico - In the buildings nos. 1 and 42 (site chronology: 100-1023; Gazzola 2009 reporting personal communications and Ladrón de Guevara 1999);

- Calakmul, Campeche, Mexico - In the Royal Tomb Garra de Jaguar, dated to the Classical Period (Vázquez de Ágredos Pascual 2004);

- Palenque, southern Mexico - In the Temple of La Cruz (site chronology: $3^{\text {rd }}$ century $\mathrm{BC}-8^{\text {th }}$ century AD; Gazzola 2009 reporting a personal communication);

- Ek'Balam, Mexico - In the room 23 at the Acropolis ( 900 AD; Vandenabeele et al. 2005);

- Huaca Tacaynamo, part of the Chan Chan complex in Perú (1412-1614 AD; Brooks et al. 2008).

\section{Cinnabar for ceramic lustre}

The lustre (or better "reduced-pigment lustre") is a particular decoration with a metallic sheen (coppery, golden or silvery) and iridescent colours (yellow, amber, ruby red, brown, green, blue, violet), used in Medieval and Renaissance times for the decoration of ceramics (Caiger Smith 1985; Mason 2004). First produced in Iraq (esp. Baghdad) around the $9^{\text {th }}$ century, it was then introduced in Persia (e.g., Kashan in Iran) and in some Mediterranean countries such as Egypt and Spain (esp. Almeria and Malaga, followed by Manises, Muel, Paterna and Valencia). Later, the technique arrived in Italy (esp. Gubbio and Deruta followed by Cafaggiolo, Faenza and Naples) probably thanks to the mediation of Pinturicchio. It is likely that this Umbrian painter became aware of this technique during the works carried out for Pope Alessandro VI Borgia at Rome (Caiger Smith 1985; Padeletti and Fermo 2003a, 2003b; Hess 2004).

Each region developed its own recipes and procedures so much so that the final products differ in decoration and visual appearance. For example, metal reflectivity is a characteristic of Spanish products not found in Syrian or Egyptian lustre (Molera et al. 2007). At a smaller scale, Deruta and Gubbio (at $43 \mathrm{~km}$ as the crow flies) developed two different styles, respectively characterised by "a copper-oxide luster and a brassy, straw-colored sheen" and a "silver-oxide luster and a more golden reddish gloss" (Hess 2004).

As reported in the literature, several recipes were handed down by several authors such as:

(1) Muhammad al-Jowhar al-Neyhapuri in his treatise Jowhar-name-ye Nezami in 1196 Iran (Pradell et al. 2004; Pérez-Arantegui and Pardos 2008);

(2) Abu'l Qasim of Kashan in 1301 (Pérez-Arantegui and Pardos 2008);

(3) Gaetano Milanesi in 1864, publishing three treatises on glass manufacture (Trattato secondo di Benedetto di Baldassare Ubriachi presumably of the $14^{\text {th }}$ century in Milanesi 1864; Pérez-Arantegui and Pardos 2008);

(4) Nicolau de Reyner of Barcelona in his Libre de les Fornades in the years 1514-1519 (Pradell et al. 2004; Pérez-Arantegui and Pardos 2008); 
Table 5 Cinnabar on architectural structures from the $4^{\text {th }}$ century AD onwards (some examples for Europe, Africa and Asia)

\begin{tabular}{|c|c|c|c|c|}
\hline Type & Location & Country & Chronology & References \\
\hline $\begin{array}{l}\text { Wall painting (fresco and } \\
\text { secco retouches) }\end{array}$ & Roman villa of Lod & Israel & $4^{\text {th }}$ & Piovesan et al. 2016 \\
\hline Wall (secco) & Maiji Mountain Grottoes, Tianshui & China & $6^{\text {th }}-19^{\text {th }}$ & Liu et al. 2016 \\
\hline Wall painting & Barone and Leonesse Tomb, Tarquinia & Italy & $6^{\text {th }} \mathrm{BC}$ & Barone et al. 2018 \\
\hline $\begin{array}{l}\text { Walls, reliefs and Buddha } \\
\text { statues }\end{array}$ & $\begin{array}{l}\text { Caves no. } 512 \text { and 689. Guangyuan Thousand-Buddha Grotto, } \\
\text { Sichuan }\end{array}$ & China & $618-907$ & He et al. 2012 \\
\hline Wall (fresco) & 12 Byzantine churches, Mani Peninsula & Greece & $10^{\text {th }}-15^{\text {th }}$ & Hein et al. 2009 \\
\hline Wall painting & Feng Hui tomb, Bin County, Shaanxi Province & China & $907-960$ & Wang et al. 2004 \\
\hline Wall painting (fresco) & Monastery of San Baudelio de Casillas, Soria & Spain & $11^{\text {th }}$ & Edwards et al. 2001 \\
\hline Wall painting & Mosque of al-Qarawiyyin, Fez & Morocco & $11^{\text {th }}-12^{\text {th }}$ & Fikri et al. 2018 \\
\hline $\begin{array}{l}\text { Wall painting (fresco, } \\
\text { mezzo fresco) }\end{array}$ & St. Maria Veterana, Triggiano, Bari & Italy & $11^{\text {th }}-16^{\text {th }}$ & Fioretti et al. 2020 \\
\hline Wall (fresco-secco) & Yemrehanna Krestos Church, Mount Abuna Yosef & Ethiopia & Early $12^{\text {th }}$ & $\begin{array}{l}\text { Gebremariam et al. } \\
2013\end{array}$ \\
\hline Wall & Fortress at Mount Sofeh, Isfahan & Iran & $12^{\text {th }}$ & Holakooei et al. 2020 \\
\hline $\begin{array}{l}\text { Wall (fresco and lime } \\
\text { painting) }\end{array}$ & By Manuel Panselinos. Protaton Church, Mount Athos & Greece & $13^{\text {th }}$ & Daniilia et al. 2000 \\
\hline $\begin{array}{l}\text { Stalactite vaults, } \\
\text { plasterwork }\end{array}$ & Hall of the Kings, Alhambra, Granada & Spain & $13^{\text {th }}-15^{\text {th }}$ & $\begin{array}{l}\text { Dominguez-Vidal } \\
\quad \text { et al. } 2012,2014\end{array}$ \\
\hline Wall painting (fresco) & Islamic style. Convento de la Peregrina, Sahagun & Spain & $13^{\text {th }}$ & Edwards et al. 1999a \\
\hline Wall (fresco, secco) & Church of St. Gallus in Kuřivody, northern Bohemia & Czech Republic & $2^{\text {nd }}$ half $13^{\text {th }}$ & Hradil et al. 2014 \\
\hline Sculptures and reliefs & West and south portals, Parma baptistery & Italy & $13^{\text {th }}(?)$ & Pinna et al. 2020 \\
\hline Wall painting (fresco) & Convento de la Peregrina, Sahagun, Léon & Spain & $13^{\text {th }}$ & Rull Perez et al. 1999 \\
\hline Marble capitals & Alhambra complex, Granada & Spain & $14^{\text {th }}(?)$ & Arjonilla et al. 2016 \\
\hline Wood ceiling & $\begin{array}{l}\text { Hall of the Abencerrages, Hall of the Two Sisters - Alhambra, } \\
\text { Granada }\end{array}$ & Spain & $14^{\text {th }}$ & Arjonilla et al. 2019a \\
\hline $\begin{array}{l}\text { Plasterwork - scalloped } \\
\text { arches }\end{array}$ & $\begin{array}{l}\text { Salón de Embajadores, Mudéjar Palace of the Real Alcázar, } \\
\text { Seville }\end{array}$ & Spain & $14^{\text {th }}-17^{\text {th }}$ & $\begin{array}{l}\text { Blasco-López et al. } \\
\quad 2016\end{array}$ \\
\hline $\begin{array}{l}\text { Woodwork - carved } \\
\text { polychrome carpentry } \\
\text { (tempera grassa) }\end{array}$ & Hall of the Mexuar Palace, Alhambra, Granada & Spain & $1314-1325$ & Cardell et al. 2009 \\
\hline $\begin{array}{l}\text { Wall painting and } \\
\text { stuccoes }\end{array}$ & $\begin{array}{l}\text { Alhambra (Granada): east wall of the Hall of the Mexuar, façade } \\
\text { of the gate of the Mexuar, east pavilion in the Lions Courtyard } \\
\text { (Lions Palace), Gonz lez Pareja House in Partal Palace }\end{array}$ & Spain & $\begin{array}{l}14^{\text {th }} \text { and } \\
\text { beyond }\end{array}$ & $\begin{array}{l}\text { Cardell-Fernández } \\
\text { and } \\
\text { Navarrete-Aguilera } \\
2006\end{array}$ \\
\hline $\begin{array}{l}\text { Wall painting } \\
\quad \text { (fresco-secco) }\end{array}$ & $\begin{array}{l}\text { Panagia Church at Patsos and Church of Theotokos in Meronas, } \\
\text { Amari, Crete }\end{array}$ & Greece & $14^{\text {th }}$ & Cheilakou et al. 2014 \\
\hline $\begin{array}{l}\text { Wall painting (fresco, } \\
\text { secco) }\end{array}$ & By Ambrogio Lorenzetti. St. Augustine church, Siena & Italy & $1335-1338$ & Damiani et al. 2014 \\
\hline Wall painting & Patio de las Doncellas, Reales Alcazares, Sevilla & Spain & $14^{\text {th }}-16^{\text {th }}$ & $\begin{array}{l}\text { Durán-Benito et al. } \\
2007\end{array}$ \\
\hline Wall painting (fresco) & $\begin{array}{l}\text { Church of SS Cosmo and Damian at Basconcillos del Tozo, } \\
\text { Castille y Léon }\end{array}$ & Spain & $14^{\text {th }}$ ? & $\begin{array}{l}\text { Edwards et al. 1999a, } \\
\quad 1999 \mathrm{c}\end{array}$ \\
\hline $\begin{array}{l}\text { Red pigments on stone } \\
\text { (moulded architectural } \\
\text { fragments) }\end{array}$ & $\begin{array}{l}\text { Augustinian friary at the Magistrates Court Site, Kingston upon } \\
\text { Hull, England }\end{array}$ & UK & $14^{\text {th }}-16^{\text {th }}(?)$ & Edwards et al. 2010 \\
\hline Vaulted ceiling & Alhambra's Hall of the Kings, Alhambra, Granada & Spain & $14^{\text {th }}$ & $\begin{array}{l}\text { Gómez-Morón et al. } \\
2016\end{array}$ \\
\hline Wall (fresco, secco) & Dominican Monastery in Ptuj & Slovenia & $\begin{array}{l}3^{\text {rd }} \text { quarter of } \\
\text { the } 14^{\text {th }}\end{array}$ & Gutman et al. 2014 \\
\hline Wall painting & Princely church of Curtea de Arges & Romania & $14^{\text {th }}$ & Ionescu et al. 2004 \\
\hline \multirow[t]{2}{*}{ Wall (fresco-secco) } & $\begin{array}{l}\text { Churches of Sts. Georgios Vounou, Nikolaos Kyritzi and } \\
\text { Nikolaos Magaliou at Kastoria }\end{array}$ & Greece & $14^{\text {th }}-17^{\text {th }}$ & Iordanidis et al. 2011 \\
\hline & Dagaoxuan Taoist Temple, Beijing & China & $1368-1912$ & Lei et al. 2017 \\
\hline
\end{tabular}


Table 5 (continued)

\begin{tabular}{|c|c|c|c|c|}
\hline Type & Location & Country & Chronology & References \\
\hline \multicolumn{5}{|l|}{$\begin{array}{l}\text { Walls, ceiling, architrave, } \\
\text { etc. }\end{array}$} \\
\hline Wall painting & Façade of the King Pedro I Palace, Alcázar of Seville & Spain & $1356-1366$ & $\begin{array}{l}\text { López Cruz et al. } \\
\quad 2011\end{array}$ \\
\hline Wall painting (fresco) & Royal Wawel Cathedral in Krakow & Poland & $14^{\text {th }}-15^{\text {th }}$ & $\begin{array}{l}\text { Rafalska-Lasocha } \\
\text { et al. } 2010\end{array}$ \\
\hline Stuccoes & Oratory room, Islamic University Madrasah Yusufiyya, Granada & Spain & $\begin{array}{l}14^{\text {th }} \\
\quad \text { (origina- } \\
1 \text { ) }-19^{\text {th }} \\
\text { retouches }\end{array}$ & $\begin{array}{l}\text { Romero-Pastor et al. } \\
\text { 2011a }\end{array}$ \\
\hline Wall painting & Dazhao Temple, Hohhot, Mongolia & China & $1368-1644$ & Wei et al. 2010 \\
\hline Wall painting & Longju Buddhist temple, Guanghan, Sichuan & China & $\sim 1466-1644$ & Chen et al. 2019 \\
\hline Wall (fresco) & Saint Stephen's chapel, Val Venosta, Bozen, Italy & Italy & $\sim 15^{\text {th }}$ & Costantini et al. 2020 \\
\hline Wall (fresco-secco) & Monastery church Christ Antiphonitis, Kalogrea, Kyrenia & Cyprus & End of $15^{\text {th }}$ & $\begin{array}{l}\text { Daniilia et al. 2008a; } \\
\text { Daniilia and } \\
\text { Minopoulou } 2009\end{array}$ \\
\hline Wall painting (tempera) & Abuna Yemata Guh church & Ethiopia & $2^{\text {nd }}$ half $15^{\text {th }}$ & $\begin{array}{l}\text { Gebremariam et al. } \\
2016\end{array}$ \\
\hline Wall (fresco, secco) & Minorite church of St. Francis of Assisi, Koper & Slovenia & $15^{\text {th }}$ & Levstik et al. 2019 \\
\hline Wall painting & Forbidden City, Yanxi Hall, Bejing & China & $15^{\text {th }}$ & Liu et al. $2018 \mathrm{~b}$ \\
\hline Wall painting (fresco) & Church of Santa Maria de Hermo, Asturias & Spain & $15^{\text {th }}$ & $\begin{array}{l}\text { Pérez-Alonso et al. } \\
\quad 2004\end{array}$ \\
\hline Wall painting (fresco) & $\begin{array}{l}\text { Mirador de la Reina, Baños de Doña María de Padilla, arch of the } \\
\text { gypsum palace; Alcazar of Seville }\end{array}$ & Spain & ? from $15^{\text {th }}$ & $\begin{array}{l}\text { Pérez-Rodríguez et al. } \\
2014\end{array}$ \\
\hline Wall painting (fresco) & San Isidoro del Campo Monastery & Spain & $15^{\text {th }}$ & $\begin{array}{l}\text { Pérez-Rodríguez et al. } \\
\quad 2020\end{array}$ \\
\hline Wall painting & Chapel of the Ponthoz Castle & Belgium & $15^{\text {th }}$ ? & $\begin{array}{l}\text { Vandenabeele et al. } \\
2005\end{array}$ \\
\hline $\begin{array}{l}\text { Wall painting (fresco and } \\
\text { mezzo fresco?) }\end{array}$ & $\begin{array}{l}\text { By the Workshop of S. Lorenzo de Skofja Loka? Church of } \\
\text { Anunciación de María at Crngrob }\end{array}$ & Slovenia & $1400-1410$ & Kriznar et al. 2007 \\
\hline Wall & $\begin{array}{l}\text { By Luca Longhi (1507-1580). Sala Dantesca, Biblioteca } \\
\text { Classense in Ravenna }\end{array}$ & Italy & ca. 1580 & Fiorillo et al. 2020 \\
\hline $\begin{array}{l}\text { Mudéjar Ceiling and } \\
\text { Doors }\end{array}$ & Casa de Pilatos Palace, Seville & Spain & $16^{\text {th }}$ & Garrote et al. 2017 \\
\hline Wall painting (fresco) & Assumption Cathedral, Sviyazhsk & Russia & $\begin{array}{l}\text { Late } 16^{\text {th }} \text {-early } \\
\qquad 17^{\text {th }}\end{array}$ & $\begin{array}{l}\text { Khramchenkova et al. } \\
2018\end{array}$ \\
\hline Wall painting (fresco) & $\begin{array}{l}\text { Vaults of the Sala Vaccarini Library, Benedictine Monastery, } \\
\text { Catania }\end{array}$ & Italy & $17^{\text {th }}$ & Barone et al. 2016 \\
\hline Wall painting (secco) & Katholikon of St Stephen's monastery at the Meteora & Greece & Early $17^{\text {th }}$ & Daniilia et al. $2008 b$ \\
\hline Wall painting & Imperial Taidong Tomb (wood), Hebei Province & China & $1644-1912$ & Fu et al. 2020 \\
\hline Ceiling & $\begin{array}{l}\text { By Peter Paul Rubens (1577-1640). The Banqueting House - } \\
\text { Palace of Whitehall, London }\end{array}$ & UK & $1630-1636$ & $\begin{array}{l}\text { Vlachou-Mogire et al. } \\
2020\end{array}$ \\
\hline Wall painting & Fatih Mosque, Instanbul (Architect Mimar Mehmet Tahir) & Turkey & 1767 and 1771 & Akyuz et al. 2015 \\
\hline Wall painting & Silsangsa temple and Bulyoungsa temple & Korean & $18^{\text {th }}$ & Ha and Lee 2015 \\
\hline $\begin{array}{l}\text { Wall (fresco, secco, egg } \\
\text { tempera) }\end{array}$ & Catholicon of Saint Demetrius, Stomion, Larissa & Greece & $2^{\text {nd }}$ half $18^{\text {th }}$ & $\begin{array}{l}\text { Malletzidou et al. } \\
2019\end{array}$ \\
\hline $\begin{array}{l}\text { Wall painting (fresco and } \\
\text { tempera) }\end{array}$ & $\begin{array}{l}\text { By Konstantinos and Athanasios Zografi. Church of St } \\
\text { Athanasius, Moschopolis }\end{array}$ & Albania & 1745 & Pavlidou et al. 2008 \\
\hline Stuccoes & Presbytery, Church of Sant'Andrea, Mantua (SAM) & Italy & $18^{\text {th }}-19^{\text {th }}$ & Sansonetti et al. 2010 \\
\hline Wall painting & Room of the Beds (Royal Bath of Comares), Alhambra, Granada & Spain & $\begin{array}{l}19^{\text {th }} \text { century } \\
\text { redecoration }\end{array}$ & Arjonilla et al. $2019 \mathrm{~b}$ \\
\hline Wall paintings & Drăguțeşti wooden church, Argeş County & Romania & $1813-1814$ & Dinu et al. 2020 \\
\hline Wall painting & Church of St. Peter and St. Paul at Upton, near Newark, & UK & Early $19^{\text {th }}$ & Edwards et al. 2005 \\
\hline
\end{tabular}


Table 5 (continued)

\begin{tabular}{|c|c|c|c|c|}
\hline Type & Location & Country & Chronology & References \\
\hline Wall painting & Five Northern Provinces' Assembly Hall, Wafangdian & China & $1861-1874$ & Hu et al. 2013 \\
\hline Painted plafond (ceiling) & $\begin{array}{l}\text { By Antonio Vighi (1765-1844). Red Living Room, historical } \\
\text { house, St.-Petersburg }\end{array}$ & Russia & ca. 1830 & Petrova et al. 2019 \\
\hline Wall painting & Jokhang temple, Lhasa, Tibet & China & Mid to late $19^{\text {th }}$ & Song et al. 2018 \\
\hline Wall (tempera) & Catholicon of the Rila Monastery & Bulgaria & $1^{\text {st }}$ half $19^{\text {th }}$ & $\begin{array}{l}\text { Stamboliyska et al. } \\
\quad 2021\end{array}$ \\
\hline Wall painting & The Cistercian Abbey of Stična and The Manor of Novo Celje & Slovenia & $?$ & Škapin et al. 2007 \\
\hline
\end{tabular}

(5) Cipriano Piccolpasso from Casteldurante in his treatise Li Tre Libri dell'Arte del Vasaio, reporting in 1558 the recipes of Mastro Giorgio Andreoli (Padeletti and Fermo 2003a-b; Pérez-Arantegui and Pardos 2008);

(6) Henry Cock in his Relación del viaje hecho por Felipe II, in 1585, in Zaragoza, Barcelona y Valencia, in Morel Fatio and A. Rodríguez, Villa in 1585 (Pradell et al. 2004; Pérez-Arantegui and Pardos 2008).

Other ancient recipes were also found in other types of documents, such as those reporting the recipe of Jacinto Causada from Alcora (1765), the Ordinaciones de la
Cofradia y Gremio de Alfareros y Vajilleros (Ordinances of the Fraternity and Guild of Potters) and a formal request emitted by the chief magistrate of Valencia in 1785 (PérezArantegui and Pardos 2008). In this regard, also the distinction made by Caiger Smith (1985) between passive and active recipes is worth mentioning considering that the active ones are those using cinnabar.

All these recipes are discussed in detail by Pérez-Arantegui and Pardos (2008) and reported in Padeletti and Fermo (2003a, 2003b), Pradell et al. (2004) and Roqué et al. (2008) to which the reader is referred for details. Here, it is interesting to note that only the treatises at points 1, 4, 5 and 6 and the

Table 6 Cinnabar on icons (some examples from Europe and Africa). Conservation sites in square brackets

\begin{tabular}{|c|c|c|c|}
\hline Artwork & Findsite [Conservation site] & Chronology & Reference \\
\hline Life of the Virgin and Christ & $\begin{array}{l}\text { St. Mercurius Church, St. Mercurius monastery, } \\
\text { Old Cairo, Egypt }\end{array}$ & $13^{\text {th }}$ & $\begin{array}{r}\text { Abdel-Ghani } \\
\text { et al. } 2009\end{array}$ \\
\hline St. Nicholas (tempera) & $\begin{array}{l}\text { Church of Ascension in Mborje, Korçë, Albania } \\
\text { [Museum of Medieval Art of Korçë] }\end{array}$ & $14^{\text {th }}$ & $\begin{array}{l}\text { Franceschi et al. } \\
\quad 2011\end{array}$ \\
\hline $\begin{array}{l}\text { Pietà, Virgin and Child, Virgin unfolding Rose and Saints, St. } \\
\text { Panteleimon, Deesis, St. Menas (modified egg tempera) }\end{array}$ & Byzantine painting art of northern Greece & $14^{\text {th }}-19^{\text {th }}$ & $\begin{array}{l}\text { Lazidou et al. } \\
\quad 2018\end{array}$ \\
\hline St. George with scenes (tempera) & $\begin{array}{l}\text { Church of St. Nicholas in Boboshtica, Korçë, } \\
\text { Albania [Museum of Medieval Art of Korçë] }\end{array}$ & $15^{\text {th }}$ & $\begin{array}{l}\text { Franceschi et al. } \\
2011\end{array}$ \\
\hline Cretan painters & [Benaki Museum, Athens, Greece] & Mid $15^{\text {th }}-17^{\text {th }}$ & $\begin{array}{l}\text { Karapanagiotis } \\
\text { et al. } 2009 \text {, } \\
2013\end{array}$ \\
\hline Saint Theodore El-Shatby by Anstasy Al-Rumi (tempera) & $\begin{array}{l}\text { Painted at Jerusalem (inscribed) [Church of } \\
\text { Saint Theodore El-Shatby, Deir } \\
\text { EL-Sankoria, El Minia] }\end{array}$ & $1549 / 19^{\text {th }}$ & $\begin{array}{l}\text { Abdel-Maksoud } \\
\text { et al. } 2020\end{array}$ \\
\hline $\begin{array}{l}\text { Our Lady, the Life-giving Spring; Saint Athanasios the Athonite (egg } \\
\text { tempera) }\end{array}$ & $\begin{array}{l}\text { [Saint Modestos's Church in Kalamitsi, } \\
\text { Chalkidiki] }\end{array}$ & $16^{\text {th }}$ & $\begin{array}{l}\text { Daniilia et al. } \\
2002\end{array}$ \\
\hline Ethiopian icons & $\begin{array}{l}\text { [National Museum of African Art, Smithsonian, } \\
\text { USA] }\end{array}$ & $17^{\text {th }}-19^{\text {th }}$ & James 2005 \\
\hline $\begin{array}{l}\text { Daniel and Jeremiah prophets and Aaron and Gideon prophets } \\
\text { (tempera) }\end{array}$ & Greek school style [Romania?] & Early $18^{\text {th }}$ & Bratu et al. 2016 \\
\hline $\begin{array}{l}\text { Last Judgement by Greek master Ioannis from Kapesovo (egg } \\
\text { tempera) }\end{array}$ & [Byzantine Museum of Ioannina, Greece] & 1771 & $\begin{array}{l}\text { Kovala-Demertzi } \\
\text { et al. } 2012\end{array}$ \\
\hline $\begin{array}{l}\text { Saint Nicholas; Saint Basil the Great; Saint John Baptist; Our Lady } \\
\text { of seven sorrows; The Lord Christ entrance into Jerusalem (egg } \\
\text { tempera) }\end{array}$ & $\begin{array}{l}\text { Antim Monastery, Bucharest - One-wood } \\
\text { Monastery, Valcea county, Romania }\end{array}$ & $\begin{array}{l}1^{\text {st }} \text { half of } \\
\text { the } 19^{\text {th }}\end{array}$ & $\begin{array}{l}\text { Serafima et al. } \\
\quad 2019\end{array}$ \\
\hline Minoan icon by Nevjanska school & $\begin{array}{l}\text { [Manastir Pokrova Presvete Bogorodice, Lešje, } \\
\text { Paraćin, Serbia] }\end{array}$ & $19^{\text {th }}$ & $\begin{array}{l}\text { Stojanović et al. } \\
2015\end{array}$ \\
\hline
\end{tabular}


recipe of Jacinto Causada inform about the use of cinnabar. Therefore, its use is to be considered widespread but not mandatory to produce lustre.

The numerous archaeometric analyses allow the main characterising feature of lustre to be described as a few hundred nanometres thick layer, including silver and/or copper nanocrystals dispersed in a glassy matrix.

The production required three firings:

(1) firing of the biscuit at about $900-1000^{\circ} \mathrm{C}$;

(2) glazing (likely by immersion) and subsequent firing;

(3) painting of the lustre decoration (dissolved in vinegar) and subsequent firing in a $480-600^{\circ} \mathrm{C}$ temperature range and a reducing atmosphere (but not fully reducing, see Molera et al. 2007), able to reduce $\mathrm{Cu}$ and/or Ag compounds into the metal state.

The materials used and the procedures adopted in the three phases all affect the final appearance of lustre and characterise specific products. For example, among all possible types of glazes, (a) the tin-opacified lead-alkali were the preferred ones (Tite et al. 1998), (b) lead-containing glazes were necessary to obtain a metal-like reflectivity (Molera et al. 2007) and (c) the Italian glazes were often characterised by higher $\mathrm{Na}_{2} \mathrm{O}$ contents than those measured in Spanish products (Padeletti and Fermo 2003a).

Among the key factors responsible for the appearance of the end product, it is possible to enlist:

- the (nanometric) dimension, composition and distribution of the particles (for iridescent metallic sheen),

- the firing and annealing temperatures (influencing the size of the final particles),

- the atmosphere conditions (influencing the reduction of $\mathrm{Cu}$ and $\mathrm{Ag}$ compounds), and

- the relative ratio of $\mathrm{Cu}$ and $\mathrm{Ag}$ and their absolute amounts (for colour variations).

The key factors mentioned above have all been investigated in detail and discussed in Molera et al. (2001), PérezArantegui et al. (2001), Padeletti and Fermo 2003a, 2003b, 2004), Padovani et al. (2003, 2004), Pérez-Arantegui et al. (2004), Pradell et al. (2004), Pradell et al. (2005), Padovani et al. (2006), Smith et al. (2006), Cepriá et al. 2007, Molera et al. (2007), Pérez-Arantegui and Pardos (2008), Pradell et al. (2008a-b), Roqué et al. (2008) and Fermo and Padeletti (2012).

These milestone papers represent the essential starting point for tackling a study of lustre and I, therefore, refer to these authors for the necessary insights. Here, I will focus on why cinnabar was used, although it decomposes completely during firing and, therefore, there is no trace of it in the finished products.
Experimental archaeometry performed by Pradell et al. (2004, 2008b), Cepriá et al. (2007), Molera et al. (2007) and Roqué et al. (2008) has clearly shown that the presence of cinnabar is relevant during firing rather than in the characteristics of the final product.

The decomposition of metacinnabar creates a sulphoreducing atmosphere that reduces tenorite $(\mathrm{CuO})$ to cuprite $\left(\mathrm{Cu}_{2} \mathrm{O}\right)$. In a temperature range between 400 and $600^{\circ} \mathrm{C}$, the released sulphur forms copper and silver sulphite (e.g., $\mathrm{Ag}_{2} \mathrm{SO}_{3}$ ), sulphate and sulphide (e.g., $\mathrm{CuSO}_{4}, \mathrm{Ag}_{2} \mathrm{~S}, 3 \mathrm{Ag}_{2} \mathrm{~S}$. $\mathrm{Ag}_{2} \mathrm{SO}_{4}$ ) that prevent the alloying of $\mathrm{Ag}$ with $\mathrm{Cu}$ while mercury vapours ensure that silver compounds are not reduced to metallic silver before entering the glaze.

Undoubtedly, lustre production implies a delicate process in each phase and accidents may occur along the way. For example, the formation of $\mathrm{Ag}-\mathrm{Hg}$ compounds such as luanheite $\left(\mathrm{Ag}_{3} \mathrm{Hg}\right)$ can inhibit the formation of metallic silver. Furthermore, it has been proved by voltammetry of immobilised microparticles (VMP) studies that both iron and cinnabar promote the reduction of $\mathrm{Ag}$ and $\mathrm{Cu}$, provided that only $\mathrm{Ag}$ or only $\mathrm{Cu}$ are present. When both $\mathrm{Cu}$ and $\mathrm{Ag}$ are present, the reduction process of $\mathrm{Ag}$ is made more difficult (Cepriá et al. 2007). Consequently, the role of cinnabar varies with the variation of the present quantities of $\mathrm{Cu}$ and $\mathrm{Ag}$ because it triggers different chemical processes, induces a variation in the temperatures at which the processes take place and, inevitably, leads to products with distinct characteristics.

Despite evidence mainly obtained on Hispano-Moresque pottery, further studies on Italian lustre have also suggested the use of cinnabar as a pigment in ruby red lustres from Gubbio (Padeletti and Fermo 2004)

Among the archaeometrically investigated lustre productions, the use of cinnabar has been assessed for both Hispano-Moresque $\left(13^{\text {th }}\right.$ century Les Olleries Xiques workshop at Paterna, Valencia, Spain; Molera et al. 2001) and Italian lustres $\left(15^{\text {th }}-17^{\text {th }}\right.$ century majolicas from Gubbio; Padeletti and Fermo 2004); however, the quantification of $\mathrm{Hg}$ is not a common routine.

\section{Cinnabar in lacquered objects}

The lacquer is a natural resin chiefly composed of catechol derivatives that "polymerizes by the oxidation of urushiol with catalysts of laccase during the drying process" (Ma et al. 2017). The composition of the lacquers varies according to the tree from which the sap is extracted, and, on this basis, it is possible to draw meaningful geographical distinctions:

- the Rhus vernifera grows in China, Japan and Korea and urushiol is the characteristic component of the lacquer it produces; 
- the Rhus succedanea grows in Vietnam and Taiwan (Formosa) and laccol characterises the composition of this lacquer;

- the Melanorrhoea usitate grows in Laos, Myanmar, Tailand and Cambodia and thitsiol identifies its lacquer.

The production technology, hardening and stability of these three types of lacquers have been studied, among others, by Kumanotani (1995), Niimura et al. (1996a, 1996b), Niimura and Miyakoshi (2006), Lu et al. (2007), Frade et al. (2009) and Ma et al. (2014).

Lacquerware has been and still is popular throughout Asia. It has been used for multiple purposes, ranging from the decoration of objects such as tableware and furniture to the decoration of inscribed plaques, jewellery and coffins.

Indian, Burmese, Thai and Japanese and, finally, European decorations are well known. The production period probably begins in the Stone Age and reaches up to the present day. The oldest examples are likely represented by Japanese (e.g., the Stone Age arrowheads; see Niimura et al. 1999 and references therein) and Chinese objects (see below). Vietnamese products also include particularly ancient lacquer decorations, dated to the Dong Son culture (i.e. more than 2000 years ago) (Naziree 2013). Conversely, Burmese lacquer-the socalled thitsi-appears chronologically later basing on archaeological evidence. Nevertheless, Tamburini et al. (2019) pointed out that it "has probably been used for more than a millennium".

Unfortunately, most of the studies concerning Asian lacquers did not concern the pigment palette identification; therefore, the archaeometric case studies reporting on cinnabar use are few and mainly concern Chinese products.

In China, the oldest examples date back to the Chinese Neolithic age; however, the authors disagree on which is the oldest lacquered object found so far. Based on Ma et al. (2017), the oldest example is represented by a black lacquered bowl dated to 8000 years BP, found at Kuahuqiao (Xiaoshan, Zhejiang). Based on Li et al. (2009) and Wang et al. (2018), the oldest example is represented by the cinnabar-containing lacquer-painted wood bowl found at the Hemudu site (Yu-yao, Zhejiang) and dated to more than 7000 years BP. Li et al. (2009) also propose a map of the lacquerware distribution between the Qin (5000-206 BC) and the Han (206 BC-220 AD) Dynasties.

Starting from the Tang Dynasty (618-907 CE), it is possible to follow the development of the "carved lacquer", which reached its peak in the Qianlong Period (1736-1796 CE) and was particularly popular until the Qing Dynasty (1636-1912 CE) (Wang et al. 2018). This technique has its basic raw material in lacquer and consists of obtaining the decoration by carving a thick lacquer layer. Among the colours of carved lacquered objects (red, yellow, green and black or polychrome), the red one was the favoured and cinnabar was the preferred colouring pigment used to prepare it.

Archaeometric studies were conducted on various types of Chinese objects and provided comparable results.

- In the wood-based lacquer painting screen discovered in the Northern Wei (386-534 AD) tomb of Si-ma Jin-long (Shi-jia-zhai village, Datong, Shanxi), Li et al. (2009) identified cinnabar along with numerous other pigments such as gypsum, carbon black, orpiment and realgar.

- In the imperial lacquer plate (202 BC-8 AD) found in the Luozhuang Han tomb (Zhangqiu, Shandong), Ma et al. (2017) demonstrated that the first ground layer (over the hemp canvas) is made of organic materials (urushi, tree oil, amorphous carbon, quartz, albite and K-feldspar). The lacquer layers are made of urushi and perilla or tallow tree oil. The final red-coloured layer is made of urushi and cinnabar.

- In the lacquer objects (mostly fragments of a chariot dated to the $1^{\text {st }}$ century) found in the $22^{\text {nd }}$ and the $31^{\text {st }}$ Noin-Ula barrows in Mongolia, Karpova et al. (2017) found cinnabar, umber, iron oxides, orpiment and charcoal in the red and brown lacquers, made of urushiol, drying oil (probably tung oil) and colophony.

- In the carved lacquers (1772 AD) sampled from a decorated panel in the Forbidden City, Wang et al. (2020) identified cinnabar and orpiment as the main colourants of the red and yellow lacquers, respectively.

- In the coffin of Emperor Qianlong (1711-1799 AD) brought to light at Zunhua, in the Eastern Imperial Tombs of the Qing Dynasty, Hao et al. (2017) found a complex stratigraphy including (a) the wooden layer; (b) the lacquer ash layer ( 9 stucco layers and 10 fibres layers; the so-called wan lacquering technique) and (c) the lacquer film pigment layer, mostly consisting of organic materials (lacquer sap from Rhus vernicifera $\rightarrow$ urushiol, animal gelatin, drying oil and proteinaceous materials) and four layers of inorganic pigments: calcite, carbon black, cinnabar and gold (the so-called Jin Jiao technique, i.e., the technique applied to mix pigments and lacquer and "painting lacquer above the gold technique").

- In a birthday inscribed lacquer plaque (1866 AD), Zheng et al. (2020) found a primer lacquer layer made of calcite, cinnabar, minium and Chinese lacquer, followed by a second plaster lacquer layer made of gypsum and Chinese lacquer and a third and last layer made of Chinese lacquer.

Aside from China, a few examples of cinnabar-lacquered objects from the Japanese and Vietnamese areas have been analysed by Colomban and Mancini (2013) and Kamiya et al. (2015). Burmese lacquered objects kept at the British 
Museum in London (UK) have been the object of the archaeometric study performed by Tamburini et al. (2019).

In Europe, lacquerware began to be imported in the mid$16^{\text {th }}$ century. Around the late $17^{\text {th }}$ century, the practice of combining local furniture with lacquered Asian panels spread throughout Europe. The example presented by Bösiger (2019) well testifies this practice and the advent of French lacquer. The history of the red lacquered chest of drawers $\left(18^{\text {th }}-20^{\text {th }}\right.$ centuries), presumably realised by Charles Chevallier dit Le Jeune and François Rübestück ${ }^{4}$, has a long and complicated history that not even the many analyses were able to clarify fully. The only incontrovertible results concern (a) the use of cinnabar in the Chinese lacquer, (b) the use of minium in the French lacquer and (c) a reworking in the $20^{\text {th }}$ century confirmed by the presence of the red pigment PR3 (beta-naphtholtoluidine).

A special mention of the South American lacquers decorated with the technique called barniz de Pasto ${ }^{5}$ is deemed necessary at this point. This technique uses a native South American resin named тора тора. This phenolic resin is obtained from the Elaeagia pastoensis ${ }^{6}$ tree, which grows "in mountainous regions of western South America from Colombia to Ecuador" (Newman et al. 2015). Although initially used as an adhesive (for example, glue feathers to ceremonial plumes; see Gomezjurado Garzón 2008), its later use mainly included decorative purposes. Once soaked, heated, kneaded and masticated, the barnizadores spread in wide and thin sheets and coloured with the addition of mineral pigments (e.g., ochre) or animal (e.g., cochineal) and vegetable dyes (e.g., achiote-Bixa orellana) (Mora-Osejo 1977; Gomezjurado Garzón 2008). When a particular brilliance was sought, a layer of metal leaf - typically silver - was "sandwiched between two layers of coloured and/or uncoloured Pasto varnish" (Portell 1992). Depending on the materials used and the technique, various types of barniz could be obtained (e.g., bright, matt and chinesco) to waterproof and decorate (carved) wooden surfaces of domestic or religious materials (Fig. 10). The analyses carried out on this type of object are very limited. Consequently, also the claims of cinnabar are numerically small and concentrated on the qeros, i.e. the typical Andean drinking vessels:

- on a series of Inka mopa mopa carved and painted wooden qeros, the most common pigment was cinnabar (Pearlstein et al. 2000);

\footnotetext{
${ }^{4}$ Preserved at the Musée d'Art et d'Histoire de Genève, Switzerland.

5 Barniz (or barniz de Pasto) is the name used to indicate the resin in today's Colombia.

${ }^{6}$ The further use of the Elaeagia utilis (Goudot) Wedd by the Incas, for example, for the decoration of the qeros (wooden ceremonial drinking vessels), has been hypothesised by Newman et al. (2015).
}

- in the pink samples taken from three qeros dated to the Transitional Inka/Early Colonial period, cinnabar was found together with cristobalite, anatase and $\alpha$-quartz ${ }^{7}$ or with gypsum and anhydrite ${ }^{8}$ (Howe et al. 2018);

- in Inka-Colonial qero cups kept in several Museums in the $\mathrm{USA}^{9}$ (Newman and Derrick 2001);

- in an Inka qero excavated at Moqi (southern Peru), cinnabar and orpiment were used for the red and yellow inlays, respectively (Newman et al. 2015).

Regarding these mopa mopa objects, it is also interesting to note that not only cinnabar but also calomel has been found (see the following section on Calomel).

Lastly, it is also worth adding that the studies performed by Strahan and Tsukada (2016) revealed that cinnabar-containing lacquered objects emit small amounts of mercury vapour and may represent a source of contamination.

\section{A (very) short list of other uncommon finds and oc- currences of cinnabar (chronological order)}

- The second century - Traces of cinnabar were found on stones deemed to have served as touchstones. Together with gold and silver weapons and vessels, these stones were found in the rich burial of two males aged 40 and 60 , uncovered near the Roman army camp at Mušov (south Moravia, Czech Republic). In particular, the stone no. 12 bore traces of cinnabar as well as streaks of gold, silver, tin, lead and various types of gold and silver or gold, silver and copper alloys (Ježek et al. 2018).

- The fifth-seventh centuries - Cinnabar has been found on textiles at Samdzong in Nepal. The archaeological context includes ten shaft tombs containing 105 individuals. The collection of textiles analysed by Gleba et al. (2016) were coloured with Indian lac, munjeet, turmeric and knotweed/indigo. Those coloured with cinnabar likely recall a technique (dyeing with mineral pigments) that "was well developed in China already during the Shang (1600-1046 BCE) and Zhou (1046-256 BCE) Dynasties" and whose products were intended for the elite (Gleba et al. 2016).

- High Middle Ages - Cinnabar, mercury and antimony were used to produce counterfeits of natural bezoars. These last are masses, sometimes mixed with food, formed in the digestive tracts of some ruminants and

\footnotetext{
${ }^{7}$ Samples Private Collection 2 and Smithsonian National Museum of the American Indian no. 10/5860 in Howe et al. (2018).

${ }^{8}$ Sample Smithsonian National Museum of the American Indian no. 15/2413 in Howe et al. (2018).

${ }^{9}$ Brooklyn Museum of Art, National Museum of the American Indian/ Smithsonian Institution, Metropolitan Museum of Art, and American Museum of Natural History.
} 


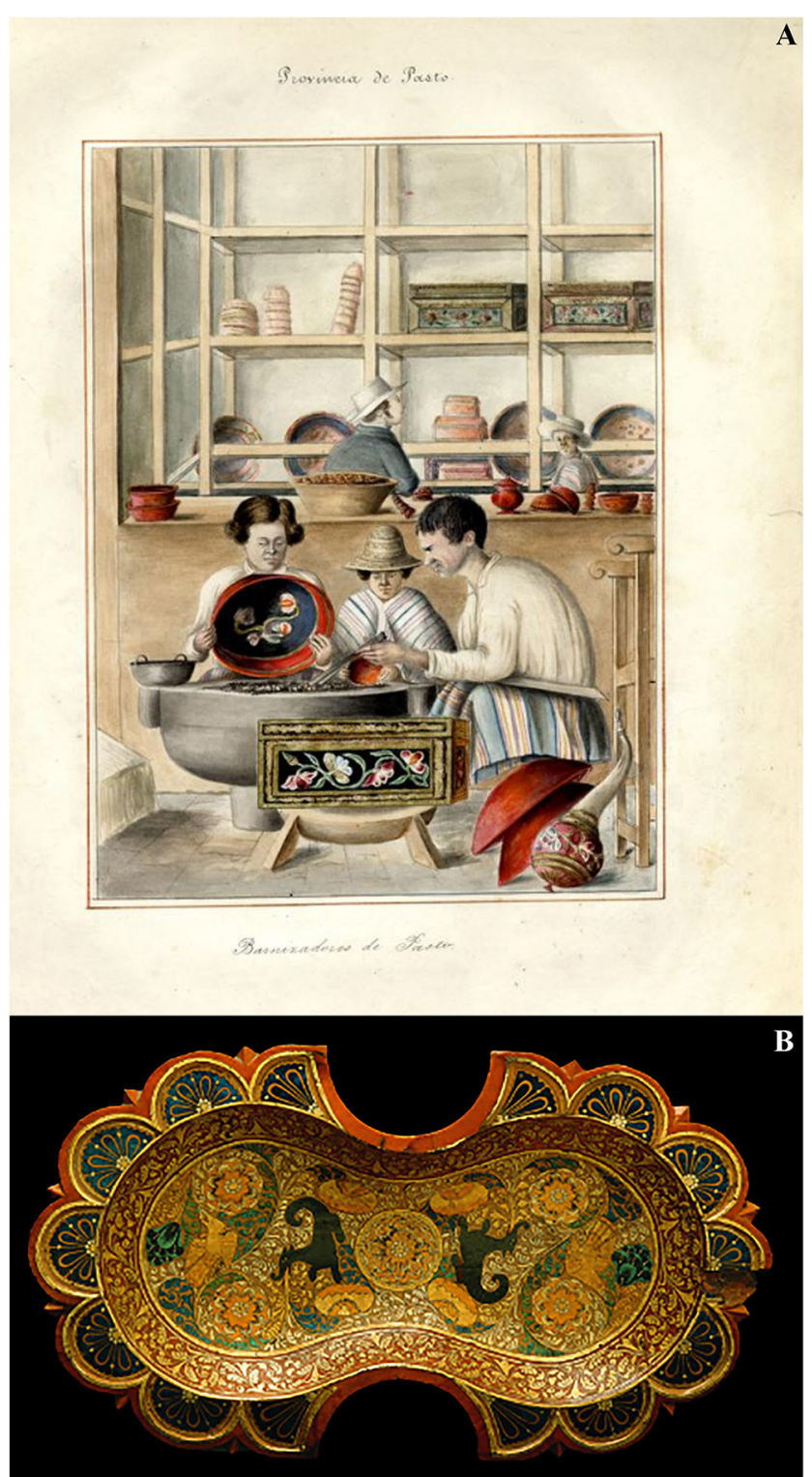

Fig. 10 A "Barnizadores de Pasto" - A watercolour made in 1853 by Manuel María Paz (1820-1902) showing three people decorating mobile objects in a shop at Pasto in Colombia. Photo from the World Digital Library (https://www.wdl.org/en/item/9074/). B Barniz de pasto: Batea lacada from Pasto in Colombia (inv. no. 12242). Dated to the $17^{\text {th }}$ century. Dimensions $5.50(\mathrm{H}) \times 43.5(\mathrm{~L}) \times 24.5(\mathrm{~W}) \mathrm{cm}$ (Photo credits: Joaquín Otero Úbeda, Museo de América. CER.es (http://ceres.mcu.es), Ministerio de Cultura y Deporte, Spain). The CC-BY licence does not supersede previously copyrighted material; therefore, these images remain under owner's copyright.

humans. Introduced to Europe by the Crusaders - together with unicorn horns - they were believed to be magical antidotes against arsenic poisoning (Barroso 2013).

- The sixteenth century - In the wreck of Gnalic various kinds of goods were found: glassy materials, semifinished metals, white lead in wooden barrels and cinnabar. The ship "Gagliana Grossa" set sail from Venice in the autumn of 1583 was headed for Constantinople (Auriemma 2018).

- The eighteenth century - The frigate HMS Pandora was dispatched (1790) to intercept mutineers on the HMS Bounty. Returning from Tahiti (March 1791), it struck the Barrier Reef and sank. Cinnabar powder associated with keratotic material (e.g., collagen) was found in a chest found in an officer's cabin (Edwards et al. 2003).

- The nineteenth-twentieth centuries - Cinnabar has been frequently used in reverse glass painting in Chinese artworks (Steger et al. (2019a), as well as in the artworks of the famous Russian artist Wassily Kandinsky (18661944; Steger et al. 2019b) and the German artist Carlo Mense (1886-1965; Steger et al. 2019c).

- Undetermined age - Human blood later reinforced by sub-micron particles of cinnabar and red ochre were found in The Turin Shroud (Fanti and Zagotto 2017 with references therein).

- While I cannot support this with proper literature, I have also found that in India, cinnabar was typically used for the Hindu practice of making the red dot on the forehead.

\section{Cinnabar procurement and trade}

I warn the reader that while the investigations carried out on finished products are consistent, those relating to mines, processing and trade are much smaller. The discussion of the various topics is therefore limited and geographically unbalanced.

In Europe, apart from the Almaden district's mines in Spain, the information on which mines were exploited in ancient times is still scarce or scattered in hardly accessible publications. Perhaps the exception is the case of the mines of Mt. Altai in Serbia, where the archaeological excavations brought to light several findings of great interest. Several authors claimed that the exploitation of the Suplja Stena mine (Mt. Avala, Belgrade), was already running as early as the $4^{\text {th }}$ millennium BC (Jovanovic 1978; Shepherd 1980 reporting the opinion of Childe 1957). This statement is likely true also considering that, before 1968 , it was the only mercury mine in the whole territory of Serbia (Gajić-Kvaščev et al. 2012). As for Spain, a map of the primary cinnabar deposits probably exploited since ancient times is provided by Domínguez-Bella (2010). Other isolated cases seem deduced more from cinnabar discovery in the neighbouring archaeological sites than from investigations aimed at verifying ancient exploitation. In other cases, the information is linked to modern exploitation. Therefore, one remains in doubt about when the exploitation began (e.g., Monte Amiata in Tuscany). 
In China and Japan, the Wanshan mine (Guizhou, China), the XunYang mine (Shaanxi, China), the Niu mine (Mie, Japan), Yamato-Suigin mine (Nara, Japan) and Sui mine (Tokushima, Japan) were identified as ancient mines (Kawano et al. 2014).

In Meso- and South America, the Peruvian-Ecuadorian case is perhaps the one that has received the greatest attention because a real controversy has arisen over the exploitation of cinnabar from Huancavelica (Peru) and that of Azogues (Cañar, Ecuador). As far as it is possible to reconstruct, the casus belli is represented by Truhan et al. (2005) paper. During an excursion to Loma Guaschon, they found cinnabar deposits already reported in previous documentation. After providing the reader with various information about the mining exploitation of some Ecuadorian, Colombian and Peruvian deposits, they hypothesised that "la productividad del cinabrio azogueño durante la temprana colonia fue de tal magnitud que la misma Fuente puede haber tenido importancia en las redes de intercambio precolombinas" $"$.

Burger et al. (2016) responded by claiming the primacy of Huancavelica in prehispanic times. These authors argued about the correctness of the interpretation of the documents presented by Truhan et al. (2005) and strongly opposed the "Ecuadorian cinnabar hypothesis". For clarity, Burger et al. (2016) did not object that there was a trade network between Ecuador and Peru (witnessed by other types of goods such as spondylus, strombus and conus) as to the fact that cinnabar was part of these trades. Burger and coworkers seriously questioned the very existence of mercury mines in Azogues. They pointed out that cinnabar had not been unequivocally identified "in any prehispanic archaeological context or on any prehispanic object in an Ecuadorian museum or private collection". To further support their theory, they recalled the isotope (Hg) investigations obtained in 2003 (Cooke et al. 2013). The Hg-isotopic analyses were carried out on geological ores from Peru (Chonta and Huancavelica), Honduras (Jalaca), Colombia (Antioquia and Quindio), Bolivia (Cerro Colorado and Mina de Pedernal) and Chile (Algarrobo Mine) and on archaeological artefacts from Peruvian archaeological sites and/or referring to the Early Horizon and Late Intermediate period of Peruvian culture. The results assigned almost all archaeological finds to Huancavelica except for samples A15-A17, corresponding to three wooden digging boards from private collections (preserved at Metropolitan Museum of Art, New York and the National Museum of the American Indian, Washington, DC, USA). As for the latter, the

\footnotetext{
$\overline{10}$ Translated: the productivity of the Azogues cinnabar during the early colony was of such magnitude that the same source might have been important in pre-Columbian exchange networks.
}

authors stated that further analyses of raw materials were necessary to establish their provenance.

The answer was not long in coming. Bruhns et al. (2017) refuted the objections raised by Burger and co-authors on the documentation concerning the Azogues mines and replied with an indication that seemed fundamental to me: "“". The quarrel continued but on closer inspection, this seems a case in which only archaeometry can write the ending. Indeed, while there is no archaeological evidence to support the "Ecuadorian cinnabar hypothesis", there is not even to discard it definitively.

Other studies are available for the exploitation of sources in Mexico and Honduras sources.

In Mexico, Manzanilla (2005) claimed that the Teotihuacans likely exploited the Sierra Gorda of Queretaro sources and, possibly, also those of San Luis Potosi in the Classical period $\left(1^{\text {st }}-9^{\text {th }}\right.$ centuries). Moreover, the ancient and modern exploitation of Queretaro mines has been the object of the study performed by Campos and Muñoz (2013) to map the archaeological sites and evaluate the $\mathrm{Hg}$ contamination issues from mining.

In Honduras, Gorokhovich et al. (2020) investigated the provenance of cinnabar found in the pre-Columbian site of Copan. They carried out a field survey that led them to detect the presence of mercury in the valley. However, they believed that the field was of such limited size/extension to make it more likely to import this material rather than exploiting the local sources (e.g., those present in the Quebrada Sesesmil watershed close to the settlement). On the other hand, they believe that future research in El Tablón mountain may instead be considered promising about the possible identification of cinnabar and Asbased pigments mines.

\section{Cinnabar production technology, application and alteration}

\section{Production technology}

Theophrastus informs us about the old way of producing cinnabar (De Lapidibus, 58-60) and indicates two types of cinnabar, one natural and one artificial.

In the first category, he included the cinnabar from Iberia (I $\beta \eta \rho i ́ \alpha v)$, very hard and stony, and that found in the Colchis ('่V Kó $\lambda \chi 0 เ \varsigma)$, which was found on mountain cliffs and was brought down by shooting arrows.

In the second category, he included cinnabar coming only

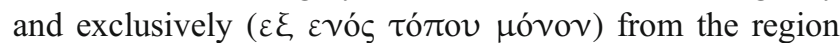
located just above Ephesus (írì $\rho$ 'E $\varphi \varepsilon ́ \sigma o v)$. According to Theophrastus, a particular sand that shone like the scarlet

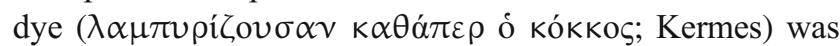
collected in this area. This sand was first pulverised in stone 
vessels until it reached the desired grain size and then washed by decanting in copper vessels. The worker then repeated the process until the achievement of the desired product. Theophrastus also added that workers' skills were essential in determining the amount of finished product (from nothing to much). The cinnabar remained at the bottom while the fraction remaining suspended in the washing water was used mainly for cosmetics.

The discovery of the procedure is attributed to Kallias, an Athenian involved in the activities of the silver mines (probably those of the Laurion) who, associating the shiny appearance of that sand with the presence of gold, would have collected and processed it, about 90 years before Praxiboulos was archon at Athens.

According to Theophrastus, this was the sign of how art imitates nature while producing its own substances. After a short digression, he describes the procedure for obtaining quicksilver ( $\chi \cup \tau$ òv $\propto$ ő $\rho \gamma \cup \rho o v)$ : grinding cinnabar with a copper pestle together with vinegar in a copper mortar.

Since it is beyond the subject of this review, I will omit to discuss the production technology regarding quicksilver and the evident differences between the procedure handed down by Theophrastus and that reported by Dioscorides (De materia medica, 5, 94; through heating cinnabar). However, it is necessary to specify two critical aspects of the text of Theophrastus.

Firstly, the territory indicated with the term Iberia by Theophrastus and later disclosed as Hispania by Plinius (Naturalis Historia 3, 4, 30; 33, 38, 113-114) ${ }^{11}$, perhaps does not correspond to Spain as to the "eastern part of the present Transcaucasian Georgia" as pointed out by Caley and Richards (1956) and Rosół (2018). On the other hand, the possible error of Pliny is well understood in the $1^{\text {st }}$ century Roman world, that is when "the most famous cinnabar mine for the revenues of the Roman nation being that in the region of Sisapo in Baetica, no item being more carefully safeguarded: it is not allowed to smelt and refine the ore upon the spot, but as much as about 2000 pounds per annum is delivered to Rome in the crude state under seal, and is purified at Rome, the price in selling it being fixed by law established at 70 sesterces a pound, to prevent its going beyond limit. But it is adulterated in many ways, which is a source of plunder for the company" (Plinius, Naturalis Historia 33, 40, 118-119, translated by Rackham 1952).

Secondly, according to Theophilus (De diversis artibus, first half of the $12^{\text {th }}$ century) the second "factitious" type was not cinnabar but, likely, minium.

Soon after, Theophilus does not fail to describe "the method of making the best vermilion, "Vermiculum optimum"

\footnotetext{
${ }^{11}$ This indication was omitted by Vitruvius (De Architectura 7, 8).
}

handed down by Petrus, of St. Audemar (MS. 6741. Bib. du Roi, Paris. Art. 174. Le Begue):

"If you wish to make the best vermilion, take a glass bottle and cover it with a lute outside; and take one part of quicksilver, by weight, and two, by weight, of white or yellow coloured sulphur. Put it into the above bottle, which you afterwards place on four stones, and, laying a very slight fire of coals round the bottle, cover its mouth with a tile, and when you see the smoke come white from the mouth of the bottle, close it, but when a smoke as red as the vermilion shall come out, take it from the fire and you will have the best vermilion. Similar recipes are found amongst the medical writers of the thirteenth and fourteenth century, but are mostly repetitions" (reported from Hendrie 1847).

Other recipes have been handed down in manuscripts such as the ancient Compositiones ad tingenda or "Lucca manuscript" $\left(8^{\text {th }}-9^{\text {th }}\right.$ centuries), the Mappae Clavicula (from the $9^{\text {th }}$ century) and the Bologna manuscript 2861 ( $15^{\text {th }}$ century).

"If you wish to make vermilion, take a glass flask and coat the outside with clay. Then take one part by weight of quicksilver and two of white or yellow sulphur and set the flask on three or four stones. Surround the flask with a charcoal fire, but a very slow one, and then cover the flask with a tiny tile. When you see that the smoke coming out of the mouth of the flask is straw-colored, cover it; and when yellow smoke comes out, cover it again; and when you see red smoke, like vermilion, coming out, then take away the fire, and you have excellent vermilion in the flask." (Mappae Clavicula, Chapter i. Vermilion; reported from Smith and Hawthorne 1974, p. 26)

"The recipe for cinnabar. Take 2 parts of clean quicksilver and 1 part of native sulphur, and put them in a flask, and, cooking them without smoke and over a slow fire, make cinnabar. Wash it properly" (Mappae Clavicula corresponding to Lucca manuscript 223v.10; reported from Smith and Hawthorne 1974, no. 105, p. 42)

"A recipe for cinnabar. A recipe for true, clean cinnabar. Take 2 parts of quicksilver and 1 part of native sulphur, and 1 part of clean urine. Take a very clean strong flask that will endure heat without smoke. Put into the flask the sulphur, ground and mixed with the quicksilver, 2 ounces short of filling it; but if it is a larger flask, it should be short 3 ounces. Mix and shake. Get 
ready a smaller glassworker's furnace, which should amply hold the flask, leaving a place where the flask may enter. Split reeds and with them light the furnace. Leave another window so that the flames may breathe out all round the flask. The sign of [completion of] the cooking is this: when you see that the flask has less purplish smoke and is making a color like cinnabar, stop adding fuel, for the flask gives a crashing sound from the great heat. When the cinnabar is thoroughly cooked leave it to cool." (Mappae Clavicula corresponding to Lucca manuscript 229.24; reported from Smith and Hawthorne 1974, no. 221C, p. 61)

"M263. To make cinnabar. Take quicksilver and two parts of white or yellow sulfur. Incorporate the finely ground sulfur with quicksilver, put it in a bottle well luted with lutum sapientiae and let dry. Then put it on the fire over a low heat and cover the mouth of the vase with a tile. Cover and uncover it frequently. When you see the yellow smoke coming out, you will know it is nearly done; let it remain and keep the fire until the smoke becomes almost peacock red. At that point you take it off the heat and let it cool and so you will have fine cinnabar" 12 (Bologna Manuscript, very similar to Mappae Clavicula, Chapter i. Translated).

Ultimately, the ancient procedures to obtain cinnabar were all relatively simple. They started from raw materials that were already well recognisable and relatively pure. They then mixed a few ingredients and let the heat do the rest, just taking care to observe the colour of the fumes. Therefore, the process did not require particularly high temperatures or complex tools. Also, the lutum sapientiae was a compound typically used for distillation and its production required raw materials that were simple to find, such as strips of linen or wool, flour, egg white, ash, dung and clay (Biringuccio, De la pirotechnia, 1540).

The production of synthetic cinnabar, on the other hand, seems to derive from a subsequent technological development, probably transferred from Arabic (Gettens et al. 1972; Miguel et al. 2014) or Chinese (Gettens et al. 1972; Franquelo and Pérez-Rodríguez 2016) artisans.

\footnotetext{
${ }^{12}$ Non-literal translation. Original text: "M263. Affare cinabrio. Abbi arge(n)to vivo et doi pa(r)te de solpho bia(n) / co o giallo et i(n)corporalo lo solpho b(e)n(e) tri / to cu(m) large(n)to et pollo i(n) una boccia alu / tata b(e)n(e) de luto de sap(ient)ia et lassa sciu / tar(e) poi la pon(e) nel fornello et fallj / foco ligiero et cop(ri) la boca del vaso cum / una tegola et spesso lo scop(ri) et ricop(re) et / q(ua)n(do) tu vedj vuscire el fumo giallo / s(e)ra ap(re)sso ch(e) facto et lassalo tanto sta / re et dallj lo foco ch(e) facia lo fumj ro / sso q(uas)i pavonazo ahlora toli via lo / foco et lassa fredar(e) e de fact(o) fino / cinabrio".
}

The feasible processes are essentially two: the dry one and the wet one. Gettens et al. (1972) reported numerous manuscript sources which, starting from the $8^{\text {th }}$ century, describe the dry process and its subsequent modifications. It consists of producing black $\beta-\mathrm{HgS}$ and heating it until it turns red $\alpha-\mathrm{HgS}$.

Melo and Miguel (2010) and Miguel et al. (2014) reproduced one of the dry process recipes contained in "The book on how to make colours" and verified that the complete grinding of $\mathrm{S}$ with $\mathrm{Hg}$ produces black $\beta$ $\mathrm{HgS}$. Based on the process described by Franquelo and Pérez-Rodríguez (2016), it would simply consist of stirring $\mathrm{Hg}$ with $\mathrm{S}$ and successively heating at $235^{\circ} \mathrm{C}$. These last authors also discuss the possible addition of small amounts of Sn.

As for the wet process, Gettens et al. (1972) seems to lead it back to Gottfried Schulz based on Kopp 18431847). In 1867, Schulz would have discovered that metacinnabar heated in a solution of ammonium or potassium sulphide transforms into vermillion. From here, it would have resulted in a production destined to become the favourite in Germany and England.

For further information on production technology, the reader is referred to the aforementioned publications. Still, it may be helpful to add that these authors have also provided optical and microscopic images and descriptions to favour the discrimination of the three types of cinnabar (i.e. natural, obtained with the dry process and obtained with the wet process) without hiding the objective difficulties. The distinction between natural and artificial cinnabar is not simple. The presence of other phases to which cinnabar may be associated in the supply source (see the associations described in the first section) undoubtedly represents the first clue but may prove insufficient.

On this topic, Franquelo and Pérez-Rodríguez (2016) discussed how the presence of impurities, the size and morphology of grains could guide the determination of natural cinnabar (generally heterogeneous in size and shape irregular) from a synthetic one (presence of K, S and Sn). However, they also note objective difficulties in distinguishing natural cinnabar from that produced through the dry process.

\section{Cinnabar application}

This topic requires two critical aspects to be addressed separately: (1) cinnabar and the fresco technique and (2) cinnabar and organic materials.

The first point is well known: cinnabar is unsuitable for painting a fresco. This incompatibility has been known since ancient times but has not limited its use to decorate wall structures. Cinnabar is poorly soluble and therefore when it comes into contact with fresh plaster (i.e. not yet dried = opposite of secco), it reacts and transforms into black metacinnabar. To 
overcome this problem, it was common to apply a red ochre base $a$ fresco and finish with cinnabar once the fresco had dried. According to fresco and lime-painting techniques, an example of the yield of cinnabar was experimentally made by Piovesan et al. (2012).

As for the second issue, the cinnabar interaction with ovalbumin and casein has been experimentally tested by Duce et al. (2012) in both unaged and aged tests. The authors observed that while cinnabar forms stable complexes with ovalbumin and promotes oxidation, it modifies the elution pattern of casein and promotes hydrolysis. The interactions with protein-based binders and fatty acid esters from egg yolk have also been investigated by Romero-Pastor et al. (2011b). They observed how the interaction of cinnabar with the protein causes a shift in the spectral region where the polyunsaturated fatty acid esters of the egg yolk appear. Further information is also provided in the study of the degradation processes involving several types of binders due to ultraviolet (UV) radiation and ageing by Ropret et al. (2007) and Romero-Pastor et al. (2012). The interaction with eastern and western drying oils was the object of the experimental study performed by Wang et al. (2015). These authors demonstrated that, compared to azurite, malachite and ochre, cinnabar is more effective in accelerating the ageing of drying oils and their hydrolysing process.

\section{Cinnabar alteration}

The colour variation of $\mathrm{HgS}$ has intrigued scholars from various fields so much that it has inspired fine philosophical discussions on the reproducibility of representations and empirical imagination in the Critique of Pure Reason by Kant (Westphal 1997).

As described above, the cinnabar $(\alpha-\mathrm{HgS}) \rightarrow$ metacinnabar $(\beta-\mathrm{HgS})$ conversion implies that the colour changes from red to black and occurs above temperatures that may vary from 315 to $400{ }^{\circ} \mathrm{C}$ depending on the surrounding conditions and the degree of purity of the mineral.

However, it is common knowledge that high temperatures are not strictly necessary to observe cinnabar's blackening on artworks. Therefore, numerous researchers studied the phenomenon more thoroughly to trace all the possible causes and discovered that metacinnabar formation is only one (rare) cause.

Firstly, McCormack (2000) highlighted that chlorine contents are decisive for cinnabar blackening. His research focused on natural deposits containing photosensitive cinnabar (generally associated with calomel, corderoite, terlinguaite and kleinite, eglestonite, comancheite, mosesite, radtkeite and kenshuite). The chemical analysis of some photosensitive cinnabar samples showed chlorine contents ranging from 0.04 to $0.96 \mathrm{wt} \%$. This evidence led the author to conclude that the "darkening of cinnabar in sunlight is caused by the presence of contained chlorine or other halogens". Furthermore, McCormack experimentally observed that nonphotosensitive cinnabar blackens to light when exposed to halogens.

Spring and Grout (2002) used McCormack's conclusions to explain the visible blackening of some artworks. They realised that the sodium chloride in the dirt particles on paints could trigger the same reaction that, in nature, induces the vermilion $\rightarrow$ corderoite transformation. This, in turn, would have led to the formation of calomel $+\mathrm{S}+$ black $\mathrm{HgS}$ upon light exposure. However, Spring and Grout further highlighted how even the painting technique is a crucial factor in the pigment's discolouration. They observed that the alteration was more prominent where cinnabar was used alone while absent or lower when applied together with red lake or red lead.

A few years later, the study by Cotte et al. (2006) returned to this topic, focusing on Pompeian frescoes. Their investigations confirmed the heterogeneous nature of the degradation products and the possible coexistence of corderoite (ascertained by spectra XANES), terlinguaite, corderoite and calomel. The authors indicated Punic wax - often used to protect frescoes and produced using seawater - as a possible chlorine source. However, they also add another possible path involving calcite sulphation, resembling the process at the origin of black crust formation.

Regarding Pompeian frescoes, the famous eruption of the Vesuvius and the corresponding temperature increase deserve further mention.

Ballirano et al. (2013) observed that the conversion temperature of the Almadén samples they investigated $(>673 \mathrm{~K}=$ $399.85^{\circ} \mathrm{C}$ ) was higher than that fixed as the formation temperature of the pyroclastic deposits of Pompeii $(653 \mathrm{~K}=$ $379.85^{\circ} \mathrm{C}$ ) and thus claimed that the blackening of Pompeian cinnabar also had to be due to impurities contained in the pigment.

What unites the work of Cotte et al. (2006) and that of Ballirano et al. (2013) is that while thinking of two different processes, both recognise the blackening of cinnabar as a process chiefly due to impurities, either naturally contained within it or brought from the outside.

On the other hand, the applied and experimental research carried out by Radepont et al. $(2011,2015)$ confirmed that both light and chlorine presence are the key factors in the discolouration of pictorial surfaces. Their main results may be summarised as follows:

(a) evaluation of the colour changes over time;

(b) identification of degradation products such as calomel, corderoite, kenhsuite, terlinguaite and sulphates;

(c) iInvestigation of the reaction sequence leading to calomel and corderoite formation (in the various layers). 
In 2013, Nöller proposed a review on cinnabar where the darkening by radiation, the influence of substrates and the reactions with halogens, other pigments and binding media are summarised. The author reports numerous discolouration examples in artworks and highlights how natural cinnabar alters differently from the artificial vermilion, depending on structural impurities (Nöller 2013). While confirming the importance of the role played by light and chlorine, the experimental work carried out by Kegelman Neiman et al. (2015) also demonstrated that high relative humidity must be added to the factors responsible for colour variations. Furthermore, the formation of calomel in tests exposed to saline solution, with or without light exposure, combined with the absence of corderoite led to a revision of the previous assumptions on reaction mechanisms and, especially, on the catalyst role of chlorine ions (see Keune and Boon 2005). Lastly, Kegelman Neiman and coworkers observed that the presence of white calomel and the absence of black corderoite made it challenging to explain the colour variations observed during alteration and cautiously put forward some hypotheses, including that of the presence of metallic mercury.

Other works have been conducted on this topic but they left the big picture unchanged; if anything, more details were presented on specific issues such as pigment-binder interactions upon weathering (e.g., Elert and Cardell 2019). Lastly, the work done by Hogan and Da Pieve (2015) on the mechanisms involved in the darkening of cinnabar is worth mentioning because it clarifies the role of chlorine. For the weathering of a sample exposed to light and humidity, the authors proposed a process in 4 steps:

(1) uptake of $\mathrm{Cl}$ on $\alpha-\mathrm{HgS}$ surface;

(2) consequent formation of $\gamma-\mathrm{Hg}_{3} \mathrm{~S}_{2} \mathrm{Cl}_{2}$ first and of the more stable cubic phase $\alpha-\mathrm{Hg}_{3} \mathrm{~S}_{2} \mathrm{Cl}_{2}$ after;

(3) structural instabilities cause the release of elemental $\mathrm{Hg}(0)$;

(4) chloride phases form (over the degradation products previously formed) and undergo further degradation processes.

In a nutshell, (a) chlorine, light and humidity or, possibly, a considerable temperature rise induce the blackening of cinnabar, (b) none of the researches presented here found metacinnabar.

The bad news is that blackening appears to be a relatively simple process to happen and, for now being irreversible, we do not currently have the means to counter it.

\section{Calomel}

The presence of calomel in an artwork is generally referred to as a degradation process. Still, on this point, we need to clarify.
The Art of limning by Nicholas Hilliard (ca. 1537/15471619 ) is often quoted in this regard (Burgio et al. 2018; Crippa et al. 2020) because the author mentions a white mercury pigment recommended for limning: "ther is also an excelent whit to be made of quicksilver/which draweth a very fine line / this whit the women painters vsse"13.

These few lines testify to the use of a mercury-based white pigment and are enough to open a little discussion. However, before going into the discussion, it must be assumed that there is no confusion with cerussite/hydrocerussite because Hilliard talks about lead white production a few lines above. The fact that Hilliard delimits the use of this pigment to "women painters" is perplexing. Thornton and Cain (i.e. the editors of his treatise) suggest that Hilliard was referring to the painter Levina Teerlinc, "appointed paintrix to Henry VIII around 1546 ", but one may also think that he refers to the cosmetic use of the contemporary sublimates.

This last reading is perhaps the least likely. Still, the doubt comes when it is found that Edward Norgate does not mention white quicksilver in the course of dealing with whites and that his $17^{\text {th }}$-century manuscript, Miniatura or the Art of Limning, is believed to be largely derived from Hilliard work. On the order hand, Norgate mentions "mercury Sublimata" while discussing a method to produce gold in a fine, fair and cheap way.

The nature of the "sublimate" is clearly described in the third book of "A tracte containing the artes of curious paintinge, carvinge and buildinge, written first in Italian by Paul Lomatius painter of Milan and englished by Richard Haydocke" in 1598:

\section{"Of sublimate and the bad effects thereof.}

Diverse women use Sublimate diversly prepared for increase of their beauty. Some bray it with quicksilver in a marble morter, with a wodden pestle; and this they call argentatum. Others boile it in water, \& therwith wash their face. Some grinde it with Pomatum, and fundry other waies. But this is sure, that which way soever it be used, it is very offensive to mans flesh, and that not only to the face; but unto all the other parts of the body besides, where it is applied. For proofe whereof Sublimate is called deadfier; because of his malignant, and biting nature. The composition whereof is of salte, quicksilver, and vitrioll, distilled together in a glassen vessell.

This the Chirurgions call a corrosive. Because if it bee put upon mans flesh it burneth it in a short space, mortifying the place, not without great paine to the patient.

\footnotetext{
${ }^{13}$ There is also an excellent white to be made of quicksilver which draweth a very fine line; this white the women painters use.
} 
Wherfore such women as use it about their face, haue alwaies black teeth, standing far out of their gums like a Spanish mule; an offensive breath, with a face halfe scorched, and an uncleane complexion. All which proceede from the nature of Sublimate. So that simple women thinking to grow more beautifull, become disfigured, haftening olde age before the time, and giving occasion to their husbandes to seeke strangers insteede of their wives; with divers other inconveniences."

Further information on the cosmetic use of these sublimates is provided by Karim-Cooper (2006), where another recipe handed down by Hugh Plat ${ }^{14}$ in 1600 is reported, and in the chapter "Making Calomel" of the Swiderski (2008) book.

In any case, the production of these sublimates and calomel was widespread since earlier times. For example, cosmetic use is documented in China (Needham et al. 1976) and Japan (Takamatsu 1878). Divers (1894) provides a very detailed review of Chinese and Japanese terminology and technology, further supplemented by sketches of the tools and furnaces. One of the recipes mentioned by Divers is reported more succinctly, albeit detailed, by Takamatsu (1878):

\begin{abstract}
"According to old history this substance was very early known in the year 714 (the $6^{\text {th }}$ year of Wado) when it was presented to the empress Gemmiyo from the province of Ise. Up to the present time it has been manufactured only in that province, hence it is also called Ise Oshiroi, which possessing important medicinal properties is mostly used for that purpose rather than as a pigment. (...) The mode of preparation is the following: - A mixture of 2 parts of alum, 1 part of mercury, and 1 part common salt is well pulverized in a mortar until no globules of mercury can be seen. The mass is then placed in a iron pot covered with an earthen ware cover, which is carefully luted up by means of a mixture made from wood ashes and salt water. 36 of such pots are placed in a rectangular furnace, and gradually heated by a charcoal fire for some time, meanwhile the covers are moistened with water. In this way about 2 parts of the calomel can be obtained from 1 part of mercury, subliming on the inner surface of the cover as a white crystalline powder like snow."
\end{abstract}

Recipes vary in relative quantities and procedures on both a geographical and temporal scale, but it is interesting to note the morphological similarity between the Hozukigama, the pot

\footnotetext{
${ }^{14}$ From Platt (1600) Delights for Ladies. Sig. G12v. "incorporate with a wooden pestle, and in a wooden mortar with great labour, four ounces of sublimate, and one ounce of crude Mercurie, at the least 6 or 8 houres".
}

used for sublimation (Fig. 11A), and those used for the production of lead white (see Gliozzo and Ionescu 2021 in this $\mathrm{TC})$.

Based on archaeometric evidence available to date, the deliberate use of calomel as a white pigment has been claimed for a few artworks:

- four mopa mopa objects - A $17^{\text {th }}$ century richly decorated barniz de Pasto table cabinet "probably made during the seventeenth century in the northern zone of the Vice-royalty of Peru", two barniz de Pasto gourd flasks and a barniz brilliante casket, all held by the Victoria and Albert Museum in London, UK (Burgio et al. 2018; Melchar et al. 2021). Please note that the authors refer to calomel as "mercury white", whenever it is clear that this material has been used intentionally as a pigment in its own right;

- a viceregal Spanish American barniz de Pasto gourd (mopa mopa) produced in the $17^{\text {th }}$ century (pre-1650) at Pasto in Colombia and acquired in 2014 by The Hispanic Society Museum and Library at New York in the USA (Pozzi et al. 2020);

- The "Fitzwilliam Missal" (MS 34), that is a $15^{\text {th }}$ century English illuminated manuscript "probably made in York around 1470 for Sir Richard Fitzwilliam and his wife, Elizabeth Clarell" and preserved in the Fitzwilliam Museum in Cambridge, UK (Crippa et al. 2020);

- a late $16^{\text {th }}$-century English portrait miniature "of a fashionably attired unknown lady" by Isaac Oliver's in the Fitzwilliam Museum collections (FM 3868; Crippa et al. 2020).

Conversely, calomel as an alteration product has been identified in:

- the vaults of the Hall of the Kings $\left(13^{\text {th }}-15^{\text {th }}\right.$ centuries $)$ within the Alhambra complex at Granada in Spain (Dominguez-Vidal et al. 2012);

- the Virgin and child enthroned (1461-1462) by Benozzo Gozzoli's (National Gallery, London, UK; Spring and Grout 2002);

- the oil on panel The Crucifixion of St Julia (Saint Wilgefortis Triptych, 1497) by Hieronymus Bosch (1450-1516), kept in the Gallerie dell'Accademia di Venezia (Sodo et al. 2019);

- the oil on canvas Adoration of the Magi (1624) by Peter Paul Rubens (Royal Museum of Fine Arts, Antwerp, Belgium; Radepont et al. 2011);

- the decorative panels of the Japanese tower ( 1905) in Laeken, Belgium (Vermeulen et al. 2015);

- probably, the Portrait of a Lady $(\sim 1625)$ by Peter Paul Rubens, kept at the Mauritshuis (The Hague, The Netherlands) and the Minerva and Hercules 


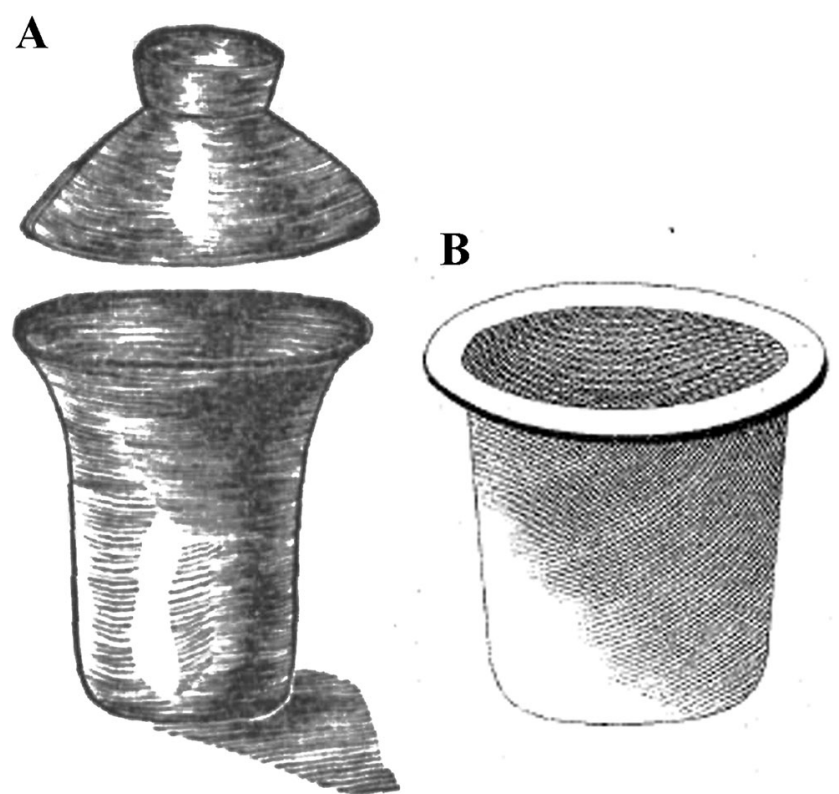

Fig. 11 A The Hozukigama (pot) and the Hozuki (lid) described by Takamatsu (1878). B The iron-furnace pot sketched by Divers (1894). For the former, the reported dimensions are 5 sun in diameter and in height, corresponding to about $15 \mathrm{~cm}$. The dimensions of the pot $\mathrm{B}$ are not indicated.

Opening the Doors for Victory (1651) by Christiaan van Couwenberg, kept at the Oranjezaal Huis ten Bosch Palace (The Hague, The Netherlands; Keune and Boon 2005);

- probably, a Pompeian wall painting (before $79 \mathrm{AD}$ ) excavated in 1988 (Cotte et al. 2006).

In conclusion, as far as we know to date, calomel may have been used as a pigment or may have formed as an alteration product. Hence, its occurrence in artworks must be discussed on a case-by-case basis.

\section{Analytical methods for a good practice}

Before going into detail, it should be noted that the choice of the methodology to adopt for investigation supports and follows the formulation of archaeological questions and the selection of samples and not vice versa. In many articles, we often read that a technique was chosen because not time-consuming and not expensive but these factors have no value in quality research. The survey methodology must be suitable to answer the research questions and respectful of the artefact's conservation. Other criteria are not to be considered a priority.

\section{Identification and characterisation of the pigment}

Identifying cinnabar would be relatively simple if we were $a$ priori sure of the absence of other Hg-based phases. However, we have seen that:
(1) other phases such as calomel may be present. Therefore, it is necessary to employ a technique capable of distinguishing the various phases with due accuracy. A simple assumption that determines cinnabar's presence by combining a red pigment's observation with mercury individuation no longer appears sufficient.

(2) the presence of impurities and the morphology of the grains may indicate the nature of cinnabar, i.e. natural or synthetic. This determination requires both microscopic observation and a technique capable of providing the chemical composition of compounds present in small amounts;

(3) the surface of the frescoes tends to form thick calcite crusts that can prevent a poorly penetrating beam from reaching the pigment. Therefore, invasive sampling is required unless the find is already detached and lends itself to being transported.

In more than 250 research studies in which cinnabar was reported, the most used techniques were Raman spectroscopy (24\%), X-ray fluorescence (XRF, 16\%), scanning electron microscopy (SEM, 17\%), Fourier transform infrared spectroscopy (FT-IR, $16 \%$ ) and optical microscopy (OM, 14\%) followed by other less common techniques such as fibre optic reflectance spectroscopy (FORS), electron microprobe analysis (EMPA), time-of-flight secondary ion mass spectrometry (ToF-SIMS), inductively coupled plasma mass spectrometry combined with laser ablation (LA-ICP-MS), particle-induced $\mathrm{X}$-ray emission (PIXE), electron paramagnetic resonance (EPR), laser-induced breakdown spectroscopy (LIBS), Mössbauer spectroscopy and the whole range of imaging techniques.

While using a single technique is inadvisable based on the limited result achievable, even the exclusive use of portable techniques may lead to a partially accurate search.

The optimum is therefore achieved with a combination of techniques capable to:

- observe the pigment (OM, SEM);

- determine the chemical composition even of elements present in small minimal quantities (SEM, EMPA, LAICP-MS or portable XRF when there is really no possibility of transferring the sample/product to the laboratory);

- provide an unquestionable phase/pigment assessment (XRD, Raman, FTIR).

Undoubtedly, the problems related to the conservation of the artefact are a priority. The help comes from the vast range of portable instruments existing to date and, above all, from large facilities such as synchrotrons. These latter offer different techniques with the advantage of optimised analytical conditions (such as penetration depth). 


\section{The provenance of the pigment}

Several authors have repeatedly attempted to determine the provenance of cinnabar through Raman spectroscopy. For example, Villar and Edwards et al. (2005) related the coexistence of cinnabar with calcium carbonates or quartz with a provenance from Tarna or Almaden, respectively. The basic assumption was that the Spanish mines exploited in Roman times were essentially two: Tarna (León) to the north, associated with sedimentary carbonates and Almaden (Ciudad Real) to the south, associated with quartz.

Recently, Botticelli et al. (2020) have made a further attempt in this direction. They obtained structural data for 31 cinnabar samples from China (Tsa Tien Mine or modern Chatian Mine, Hunan; War Shan-Chang Nmer, Guizhou, Kweichow; unspecified locality in the Hunan territory), Czech Republic (Hořovice in Bohemia), Germany (Moschellandsberg), Italy (Serravezza, Lucca; Val di Castello, Lucca; Grosseto; Miniera San Filippo, Mount Amiata; Abbadia San Salvatore, Mount Amiata; unspecified locality at Mount Amiata; Loibel Valley, Carnia, Udine), Serbia (Mount Avala), Slovakia (Rosenau), Slovenia (Idrija), Spain (Almadén) and Ukraine (Saizewka, Nikitovka, Charkov train station, Asow; Nikitovka Donetz). The results achieved were processed through statistical analysis. Some distinctions were observed between Almadén and Idrija and especially Chinese samples, further characterised by selenium's presence.

Very few authors have tried the same type of approach using XRD. For example, Maras et al. (2013) investigated several mineralogical samples from Austria (Carnia, 1 sample), China (Tsar Lien Mine, Honan, 1), Germany (Moschellandsberg, 1), Italy (Cerreto Piano, Grosseto, 2; Val di Castello, Lucca, 1; Sele Mine, Castell'Azzara, Monte Amiata, 1), Romania (Rosenau, 1), Russia (Nikitowska, Charkov railway station, 1), Serbia (Avala, 1), Slovenia (Idrija, 1) and Spain (Almadén, 3). Since the results provided measurable differences in unit cell parameters and volume (due to Hg: S variable ratios) between the various samples, the authors suggested that the method could also work in provenance studies.

These two methods could provide effective developments in the future, but it seems that both suffer from two main problems: (a) representativeness, due to the investigation of a few areas only and (b) nature of the pigment (natural or artificial). Indeed, one may wonder (a) what these methods' discriminating power could be when the items used for comparison become numerically consistent and (b) are there possible overlaps in spectra and/or structural parameters between natural cinnabar from a given location and artificial cinnabar?

Another issue that does not seem to have been addressed so far (except in part for Almaden) concerns the intra-site variability. This could represent another critical factor in the comparison.

At present, therefore, the most promising techniques seem to be isotopic ones, although much work is still needed before having sufficiently comprehensive and representative data for comparison. In this case, the archaeometric literature may also use geological studies and take advantage of a pre-existing and developing database.

As for sulphur isotopes, data on natural cinnabar occurrences are limited but particularly focused on ancient mining districts (Table 7). This method has been used for provenance investigation by Damiani et al. (2003), Minami et al. (2005), Domínguez-Bella (2010), Spangenberg et al. (2010), Kawano et al. (2014), Tsantini et al. (2018) and Minami et al. (2019). Further data on natural ores are provided by Lavrič and Spangenberg (2003) for the Idrija mine in Slovenia and Jébrak et al. (2002) for the Nuevo Entredicho deposit in Spain. The authors report different methods for sample preparation. Depending on the materials analysed, some considered an initial grinding, followed by analytical techniques such as optical microscopy and XRD, to assess the possible presence of contaminants. Others adopted more laborious procedures including the following steps: $5 \mathrm{~h}$ heating at $95^{\circ} \mathrm{C}$, dilution with a $\mathrm{HNO}_{3} / \mathrm{HCl}$ solution (3:1), washing with ultrapure water, addition of reverse aqua regia to the insoluble part followed by $5 \mathrm{~h}$ heating at $95^{\circ} \mathrm{C}$; cooling, bromine addition, $2 \mathrm{~h}$ heating at $95^{\circ} \mathrm{C}$, washing with ultrapure water, addition of $1-\mathrm{ml} \mathrm{BaCl}_{2}$, overnight heating at $65^{\circ} \mathrm{C}$, repeated washing with ultrapure water of the resulting barium sulphate, drying and addition of $1 \mathrm{mg}$ of vanadium pentoxide (see Tsantini et al. 2018 for further details). The analyses are typically carried out using isotope ratio mass spectrometers (IRMS), using pure $\mathrm{SO}_{2}$ gas as a reference. Data are conventionally reported as $\delta^{34} \mathrm{~S} \%$ (i.e. ${ }^{34} \mathrm{~S} /{ }^{32} \mathrm{~S}$ ) and standardized to the Vienna Cañón Diablo Troilite. The standards mostly used are the IAEA-S- 1 and IAEA-S-2 silver sulphides $(-0.3 \%$ and $+22.7 \pm 0.2 \%$, respectively) and, when reported, reproducibility values are better than $3 \%$.

Lead isotopes (Table 8) are consistently used for metal provenancing, first for ancient lead (Brill and Wampler 1967; Grögler et al. 1966) and later also for copper-based alloys (Gale and Stos-Gale 1982; Pernicka et al. 1990, 1993; Niederschlag et al. 2003). Their use for cinnabar investigation requires suitable sample preparation to eliminate mercury and purify lead. As a matter of fact, ${ }^{204} \mathrm{Hg}$ interferes with ${ }^{204} \mathrm{~Pb}$; moreover, the lead isotope ratios of the leachates and residues are different mainly due to lead contamination from associated phases such as pyrite (Higueras et al. 2005). For this reason, sample preparation is as crucial as the analytical technique used for the measurements. Archaeometric issues have been approached through this method by Mazzocchin et al. (2008), Hunt et al. (2011), Minami et al. (2013, 2021) 
Table 7 Sulphur isotope composition of cinnabar from several mining districts $\left(\delta^{34} \mathrm{~S}\right.$ values provided as \%o). [In the first column: Pf stands for profile. Among data from Lavrič and Spangenberg 2003, the age of host rock is indicated. For several Chinese and Japanese ores, the average value is provided, followed by the standard deviation (after \pm )]

\begin{tabular}{|c|c|c|c|c|c|}
\hline Locality & $\delta^{34} \mathrm{~S}$ & Reference & Locality & $\delta^{34} \mathrm{~S}$ & Reference \\
\hline Almaden District (Spain) & & & Idrija (Slovenia) & & \\
\hline M. Las Cuevas $(n=9)$ & $+13.6(1)^{(1)}$ & Rytuba et al. 1988 & MGL51355 & +8.2 & Spangenberg et al. 2010 \\
\hline El Entredicho $(n=3)$ & $+8.4(0.8)^{(2)}$ & Rytuba et al. 1988 & MGL51357 & +5.9 & Spangenberg et al. 2010 \\
\hline Almadén $(\mathrm{n}=8)$ & $+4.3(2.8)^{(3)}$ & Rytuba et al. 1988 & MGL51357 & +5.1 & Spangenberg et al. 2010 \\
\hline San Pedro (Pf 1) AL1740/4.1 & $+7.3(0.07)$ & Saupé and Arnold 1992 & MGL51361 & +8.5 & Spangenberg et al. 2010 \\
\hline San Pedro (Pf 1) AL17-40/4.III & +6.5 & Saupé and Arnold 1992 & MGL51361 & +9.1 & Spangenberg et al. 2010 \\
\hline San Pedro (Pf 1) AL17-40/6.I & $+5.2(0.03)$ & Saupé and Arnold 1992 & MGL51366 & +3.1 & Spangenberg et al. 2010 \\
\hline San Pedro (Pf 1) AL17-40/7.1 & $+6.4(0.04)$ & Saupé and Arnold 1992 & MGL30392 & +6.0 & Spangenberg et al. 2010 \\
\hline San Pedro (Pf 4) IV-1 & $+7.2(0.05)$ & Saupé and Arnold 1992 & MGL30392 & +7.7 & Spangenberg et al. 2010 \\
\hline San Pedro (Pf 4) IV-2 & $+6.9(0.05)$ & Saupé and Arnold 1992 & MGL51478 & +1.2 & Spangenberg et al. 2010 \\
\hline San Pedro (Pf 4) IV-3 & $+6.8(0.06)$ & Saupé and Arnold 1992 & MGL51478 & +1.5 & Spangenberg et al. 2010 \\
\hline San Pedro (Pf 4) IV-5 & $+5.9(0.05)$ & Saupé and Arnold 1992 & MGL51478 & +6.1 & Spangenberg et al. 2010 \\
\hline San Pedro (Pf 4) IV-6 & $+4.9(0.06)$ & Saupé and Arnold 1992 & MGL51478 & +7.0 & Spangenberg et al. 2010 \\
\hline San Pedro (Pf 4) IV-8 & $+4.5(0.04)$ & Saupé and Arnold 1992 & MGL51639 & +0.0 & Spangenberg et al. 2010 \\
\hline San Pedro (Pf 6) VI-1 & $+5.8(0.06)$ & Saupé and Arnold 1992 & MGL51639 & -0.9 & Spangenberg et al. 2010 \\
\hline San Pedro (Pf 6) VI-2 & $+4.5(0.05)$ & Saupé and Arnold 1992 & MGL52647 & +8.9 & Spangenberg et al. 2010 \\
\hline San Pedro (Pf 6) VI-3 & $+5.3(0.05)$ & Saupé and Arnold 1992 & MGL34995 & +1.3 & Spangenberg et al. 2010 \\
\hline San Nicolas II-11 & $+0.1(0.08)$ & Saupé and Arnold 1992 & MGL34995 & +0.5 & Spangenberg et al. 2010 \\
\hline San Nicolas II-7 & $-0.3(0.08)$ & Saupé and Arnold 1992 & MGL34995 & +4.1 & Spangenberg et al. 2010 \\
\hline San Nicolas II-5 & $+1.2(0.06)$ & Saupé and Arnold 1992 & MGL34989 & +0.0 & Spangenberg et al. 2010 \\
\hline San Nicolas II-4 & $+0.8(0.07)$ & Saupé and Arnold 1992 & MGL34989 & -0.5 & Spangenberg et al. 2010 \\
\hline San Nicolas II-3 & $+1.2(0.05)$ & Saupé and Arnold 1992 & MGL34976 & +7.1 & Spangenberg et al. 2010 \\
\hline San Nicolas II-2 & $-1.6(0.07)$ & Saupé and Arnold 1992 & MGL34996 & +7.6 & Spangenberg et al. 2010 \\
\hline San Francisco III-1 & $+7.4(0.05)$ & Saupé and Arnold 1992 & MGL34981 & +1.0 & Spangenberg et al. 2010 \\
\hline San Francisco III-2/1 & $+7.3(0.04)$ & Saupé and Arnold 1992 & JSID26 & +3.8 & Spangenberg et al. 2010 \\
\hline San Francisco III-2/3 & $+7.3(0.04)$ & Saupé and Arnold 1992 & Upper Ladinian $(\mathrm{n}=40)$ & $+6.7^{(5)}$ & Lavrič and Spangenberg 2003 \\
\hline San Francisco III-3 & $+8.2(0.04)$ & Saupé and Arnold 1992 & Ladinian, Karoli oreb. $(n=14)$ & $+0.8^{(6)}$ & Lavrič and Spangenberg 2003 \\
\hline San Francisco III-4 & $+8.1(0.05)$ & Saupé and Arnold 1992 & Anisian $(\mathrm{n}=10)$ & $+4.9^{(7)}$ & Lavrič and Spangenberg 2003 \\
\hline San Francisco III-5 & $+9(0.03)$ & Saupé and Arnold 1992 & Upper Scythian $(n=3)$ & $+5.6^{(8)}$ & Lavrič and Spangenberg 2003 \\
\hline San Francisco III-7 top & $+8.4(0.04)$ & Saupé and Arnold 1992 & Lower Scythian $(n=39)$ & $+0.6^{(9)}$ & Lavrič and Spangenberg 2003 \\
\hline San Francisco III-7 bottom & $+8.9(0.02)$ & Saupé and Arnold 1992 & Upper Permian $(n=34)$ & $-6.4^{(10)}$ & Lavrič and Spangenberg 2003 \\
\hline San Francisco III-8 & $+8.1(0.05)$ & Saupé and Arnold 1992 & Middle Permian $(n=3)$ & $+2.6^{(11)}$ & Lavrič and Spangenberg 2003 \\
\hline San Francisco III-9 & $+8.9(0.03)$ & Saupé and Arnold 1992 & Permocarboniferous & -4.9 & Lavrič and Spangenberg 2003 \\
\hline San Francisco III-10 & $+7(0.06)$ & Saupé and Arnold 1992 & Range & From -6.4 to 9.1 & \\
\hline Las Cuevas - LC-PL3-36 & +13 & Higueras et al. 1999 & Average $(n=24)$ & 3.5 & \\
\hline Las Cuevas - LC-PL3-37 & +13 & Higueras et al. 1999 & & & \\
\hline Las Cuevas - LC56 & +12.2 & Higueras et al. 1999 & Monte Amiata (Italy) & & \\
\hline Las Cuevas - 2-pow & +12.8 & Higueras et al. 1999 & MGL-Bickel & -1.6 & Spangenberg et al. 2010 \\
\hline Nuevo Entredicho 14 & +10.3 & Jébrak et al. 2002 & MGL-Bickel & -1.7 & Spangenberg et al. 2010 \\
\hline Nuevo Entredicho 18 & +10.8 & Jébrak et al. 2002 & MGL-SGAM1 & +2.3 & Spangenberg et al. 2010 \\
\hline Nuevo Entredicho 19 & +10.7 & Jébrak et al. 2002 & MGL-SGAM2 & +2.4 & Spangenberg et al. 2010 \\
\hline Nuevo Entredicho 22b & +10.6 & Jébrak et al. 2002 & MGL-NM-1 & -5.0 & Spangenberg et al. 2010 \\
\hline Nuevo Entredicho 30 & +10.7 & Jébrak et al. 2002 & MGL-ICMA & -0.8 & Spangenberg et al. 2010 \\
\hline MGL25234 & +6.6 & Spangenberg et al. 2010 & MGL-IMP & +0.1 & Spangenberg et al. 2010 \\
\hline MGL40128-1 & +6.2 & Spangenberg et al. 2010 & MGL-NM-2 & -7.6 & Spangenberg et al. 2010 \\
\hline MGL40128-2 & +5.4 & Spangenberg et al. 2010 & MGL-SGAM3 & +0.9 & Spangenberg et al. 2010 \\
\hline MGL25229 & +6.3 & Spangenberg et al. 2010 & Range & From -7.6 to 2.4 & \\
\hline MGL14308-1 & +8.8 & Spangenberg et al. 2010 & Average $(n=24)$ & -1.2 & \\
\hline MGL14308-2 & +8.0 & Spangenberg et al. 2010 & & & \\
\hline MGL51356 & +0.6 & Spangenberg et al. 2010 & Genepy (France) & & \\
\hline MGL51349 & +4.6 & Spangenberg et al. 2010 & MGL58789 & -2.2 & Spangenberg et al. 2010 \\
\hline MGL34986-1 & +4.4 & Spangenberg et al. 2010 & 1 Aupt & -3.5 & Spangenberg et al. 2010 \\
\hline MGL34986-2 & +5.1 & Spangenberg et al. 2010 & & & \\
\hline MGL34986-3 & +4.6 & Spangenberg et al. 2010 & Moschellandsberg (Germany) & & \\
\hline MGL34986-4 & +5.4 & Spangenberg et al. 2010 & MGL3499-1 & -19.6 & Spangenberg et al. 2010 \\
\hline MGL34986-5 & +7.0 & Spangenberg et al. 2010 & MGL3499-2 & -15.6 & Spangenberg et al. 2010 \\
\hline M. de Almadén & +9.6 & Domínguez-Bella 2010 & & & \\
\hline Castilla - La Mancha & +7.51 & Tsantini et al. 2018 & Turkey & & \\
\hline Castilla - La Mancha & +9.61 & Tsantini et al. 2018 & Haliköy $(n=3)$ & $-6.7 \pm 0.1$ & Akçay et al. 2006 \\
\hline Castilla - La Mancha & +6.855 & Tsantini et al. 2018 & & & \\
\hline Castilla - La Mancha & +8.365 & Tsantini et al. 2018 & China & & \\
\hline Castilla - La Mancha & +6.8 & Tsantini et al. 2018 & Qingtongguo mine $(\mathrm{n}=3)$ & $+10.54 \pm 0.14^{(12)}$ & Minami et al. 2021 \\
\hline Range & \multicolumn{2}{|c|}{ From -1.6 to +13.6} & Wanshan mine $(\mathrm{n}=15)$ & $+22.6 \pm 3.6$ & Kawano et al. 2014 \\
\hline
\end{tabular}


Table 7 (continued)

\begin{tabular}{|c|c|c|c|c|c|}
\hline Locality & $\delta^{34} \mathrm{~S}$ & Reference & Locality & $\delta^{34} \mathrm{~S}$ & Reference \\
\hline \multirow[t]{2}{*}{ Average $(n=43)$} & +5.8 & & Wanshan mine $(\mathrm{n}=9)$ & $+24.91 \pm 2.56^{(13)}$ & Minami et al. 2021 \\
\hline & & & XunYang mine $(n=4)$ & $+10.5 \pm 0.1$ & Kawano et al. 2014 \\
\hline \multicolumn{6}{|l|}{ Other localities in Spain } \\
\hline Escarlati deposit, León & $+9.75^{(4)}$ & Martín-Izard et al. 2009 & Japan & & \\
\hline M. Sultana-Mariquita, Usagre & +18.3 & Domínguez-Bella 2010 & Itomuka $(\mathrm{n}=22)$ & $-4.6 \pm 1.8^{(14)}$ & Minami et al. 2019 \\
\hline M. B.\&F. Albuñol, Granada & +4.3 & Domínguez-Bella 2010 & Ryushoden ( $\mathrm{n}=53$ ) & $-2.0 \pm 5.5^{(15)}$ & Minami et al. 2019 \\
\hline M. Sierra de Espadán Chóvar, Castellón & -6.6 & Domínguez-Bella 2010 & Meiji $(n=6)$ & $+8.4 \pm 9.5^{(16)}$ & Minami et al. 2019 \\
\hline M. Oriental Chóvar Castellón & -10.7 & Domínguez-Bella 2010 & Horokanai $(\mathrm{n}=1)$ & +9.5 & Minami et al. 2019 \\
\hline M. Encarnación, Caunedo, Asturias & +10.1 & Domínguez-Bella 2010 & Niu mine $(\mathrm{n}=34)$ & $-7.3 \pm 1.9$ & Kawano et al. 2014 \\
\hline M. La Uña, León & +10.2 & Domínguez-Bella 2010 & $\mathrm{Niu}(\mathrm{n}=58)$ & $-8.0 \pm 4.7^{(17)}$ & Minami et al. 2019 \\
\hline M. Pantano de Riaño, León & +9.1 & Domínguez-Bella 2010 & Niu $(n=28)$ & $-8.96 \pm 1.84^{(18)}$ & Minami et al. 2021 \\
\hline M. Riosol Tarna, León & +17.2 & Domínguez-Bella 2010 & Yamato $(\mathrm{n}=107)$ & $-2.4 \pm 4.4^{(19)}$ & Minami et al. 2019 \\
\hline Tarna, Asturias & +18.10 & Tsantini et al. 2018 & Yamato $(n=61)$ & $-3.34 \pm 1.76^{(20)}$ & Minami et al. 2021 \\
\hline Caravia, Asturias & +7.29 & Tsantini et al. 2018 & Yamato-Suigin mine $(\mathrm{n}=66)$ & $-2.1 \pm 1.6$ & Kawano et al. 2014 \\
\hline Riaño, León & +21.84 & Tsantini et al. 2018 & Sui mine $(n=17)$ & $-2.4 \pm 1.4$ & Kawano et al. 2014 \\
\hline Guipúzcoa, Bask Country & -23.27 & Tsantini et al. 2018 & Sui $(n=16)$ & $-4.8 \pm 3.3^{(21)}$ & Minami et al. 2019 \\
\hline Xóvar, Castelló & -7.82 & Tsantini et al. 2018 & Suii Mine $(n=13)$ & $-3.01 \pm 2.70^{(22)}$ & Minami et al. 2021 \\
\hline Unknown, Castelló & -14.65 & Tsantini et al. 2018 & Ohita $(n=3)$ & $-4.5 \pm 1.1^{(23)}$ & Minami et al. 2019 \\
\hline
\end{tabular}

${ }^{(1)}$ Range $+12.2 /+16.6 ;{ }^{(2)}$ range $+7.3 /+9.1 ;{ }^{(3)}$ range $-0.1 /+8.6 ;{ }^{(4)}$ range $+9.1 /+10.7 ;{ }^{(5)}$ range $+3.6 /+22.8 ;{ }^{(6)}$ range $+0.1 /+3.2 ;{ }^{(7)}$ range $+3.1 /+8.0 ;$ ${ }^{(8)}$ range $+4.9 /+7.0 ;{ }^{(9}$ range $+3.6 /+5.8 ;{ }^{(10)}$ range $+19.1 /+7.7 ;{ }^{(11)}$ range $+0.1 /+6.2 ;{ }^{(12}$ range $+10.39 /+10.66 ;{ }^{(13)}+21.30 /+28.10 ;{ }^{(14)}$ range $-7.6 /+0.7$; ${ }^{(15)}$ range $-20.9 /+12.7 ;{ }^{(16)}$ range $+3.9 /+27.7 ;{ }^{(17)}$ range $-15.4 /+15.6 ;{ }^{(18)}$ range $-12.28 /-5.85 ;{ }^{(19)}$ range $-11.2 /+20.2 ;{ }^{(20)}$ range $-6.90 /+2.30 ;{ }^{(21)}$ range $-1.3 /+3.3 ;{ }^{(22)}$ range $-6.21 /+3.30 ;{ }^{(23)}$ range $-5.7 /-3.1$

and Rodríguez et al. (2020). Other data on cinnabar ores have been further provided by Jébrak et al. (2002), on recrystallised pyrite and Higueras et al. (2005) on cinnabar. These authors used different preparation procedures and analytical techniques; therefore, their results bear different levels of accuracy.

Higueras et al. (2005) prepared the sample through the following procedures (in order): grinding, sieving, electromagnetic separation, ultrasonic bath, dissolution via $\mathrm{HCl}$ and $\mathrm{HNO}_{3}$, heating on a hotplate $100^{\circ} \mathrm{C}$ for 24 hours and ion exchange in hydrobromic acid. Measurements were performed using a micromass multicollector thermal ionisation mass spectrometer (TIMS). The reference standard was the SRM981 and the results bear an estimated error of $0.15-0.48 \%$ for ${ }^{206} \mathrm{~Pb} /{ }^{204} \mathrm{~Pb}, 0.13-1.07 \%$ for ${ }^{207} \mathrm{~Pb} /{ }^{204} \mathrm{~Pb}$ and $0.10-0.45 \%$ for ${ }^{208} \mathrm{~Pb} /{ }^{204} \mathrm{~Pb}$ and an overall confidence level of $95 \%$.

Mazzocchin et al. (2008) prepared the sample through the following procedures (in order): dissolution in hydrochloric and nitric acids, heating on a hotplate, cooling and addition of ultra-pure water. The analysis of the samples was performed by quadrupole inductively coupled plasma mass spectrometry (QICP-MS) to study ${ }^{206} \mathrm{~Pb},{ }^{207} \mathrm{~Pb}$ and ${ }^{208} \mathrm{~Pb}$.

Hunt et al. (2011) did not provide data regarding sample preparation and the accuracy of the proposed results. Their own measurements were achieved using TIMS.

Minami et al. $(2013$, 2021) prepared the sample through the following procedures (in order): decomposition with reverse aqua regia, dissolution in hydrochloric acid, ion exchange, dissolution by hydrochloric acid solution and nitric acid and evaporation. Measurements were made by TIMS and MC-ICP-MS.
In this second case, the measurements were corrected using the reference NIST981 and NIST99 standards. The isotopes analysed were ${ }^{204} \mathrm{~Pb},{ }^{206} \mathrm{~Pb},{ }^{207} \mathrm{~Pb}$ and ${ }^{208} \mathrm{~Pb}$. In Minami et al. (2013), the accuracy of the isotopic ratios was of $0.1-0.3 \%$ and $0.3-0.6 \%$ with ${ }^{206} \mathrm{~Pb}$ and ${ }^{204} \mathrm{~Pb}$ as the denominator, respectively ${ }^{15}$.

Rodríguez et al. (2020) prepared the sample through the following procedures (in order): preliminary digestion by $\mathrm{HNO}_{3}$ (1st day), removal of supernatant and rinsing of the residue with $\mathrm{H}_{2} \mathrm{O}$, digestion with $\mathrm{HF}$ (2nd day), removal of supernatant, rinsing of the residue with $\mathrm{H}_{2} \mathrm{O}$ and $\mathrm{XRD}$, digestion with aqua regia (3rd day), evaporation to dryness, ion exchange in hydrobromic acid, lead elution by $\mathrm{HCl}$. Measurements were made using a multicollector inductively coupled plasma mass spectrometer (MC-ICP-MS). Correction was obtained by the addition of thallium with NBS997 as isotopic reference material $\left({ }^{205} \mathrm{Tl} /{ }^{203} \mathrm{Tl}\right.$ ratio of 2.3889) and for lead the reference material NBS981 was used. Further tests allowed these authors to measure a ${ }^{204} \mathrm{Hg}$ contribution lower than $3.5 \%$ of the total intensity at mass 204 and established that "accurate $\mathrm{Pb}$ ratios are obtained for solutions containing up to $3.6 \%$ of $\mathrm{Hg}$ and for total signals above $40 \times 10^{-14}$ A on mass 204 ".

Lastly, Jébrak et al. (2002) analysed recrystallised pyrite instead of cinnabar. After assessing the absence of mercury contamination through the measurement of ${ }^{202} \mathrm{Hg}$, they analysed the samples using an ICP-MS (reproducibility of $0.12 \%, 0.16 \%$ and $0.22 \%$ for ${ }^{206} \mathrm{~Pb} /{ }^{204} \mathrm{~Pb},{ }^{207} \mathrm{~Pb} /{ }^{204} \mathrm{~Pb}$ and ${ }^{208} \mathrm{~Pb} /{ }^{204} \mathrm{~Pb}$ ratios, respectively).

\footnotetext{
${ }^{15}$ I apologise for any translation errors of the original text in Japanese.
} 


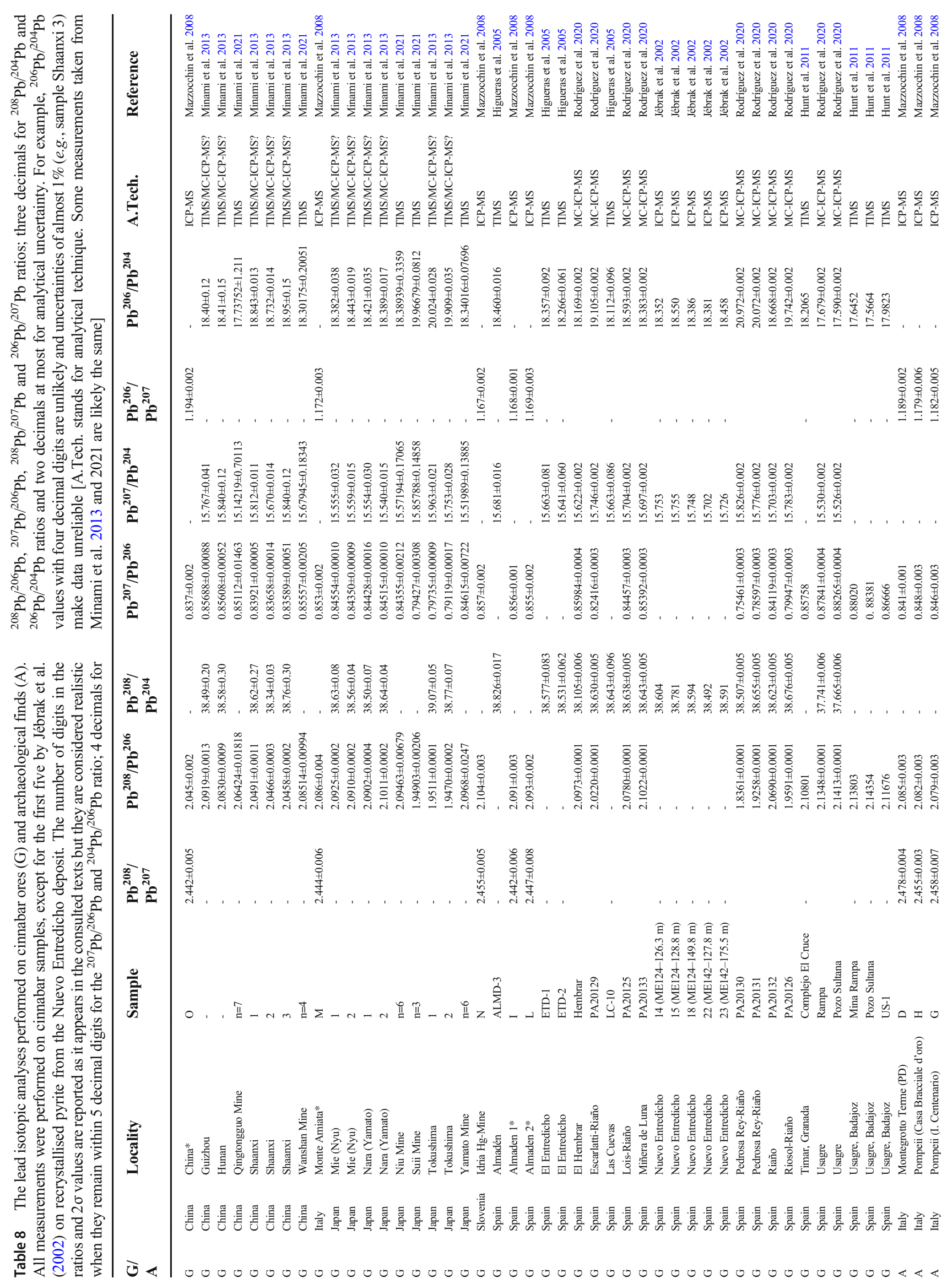




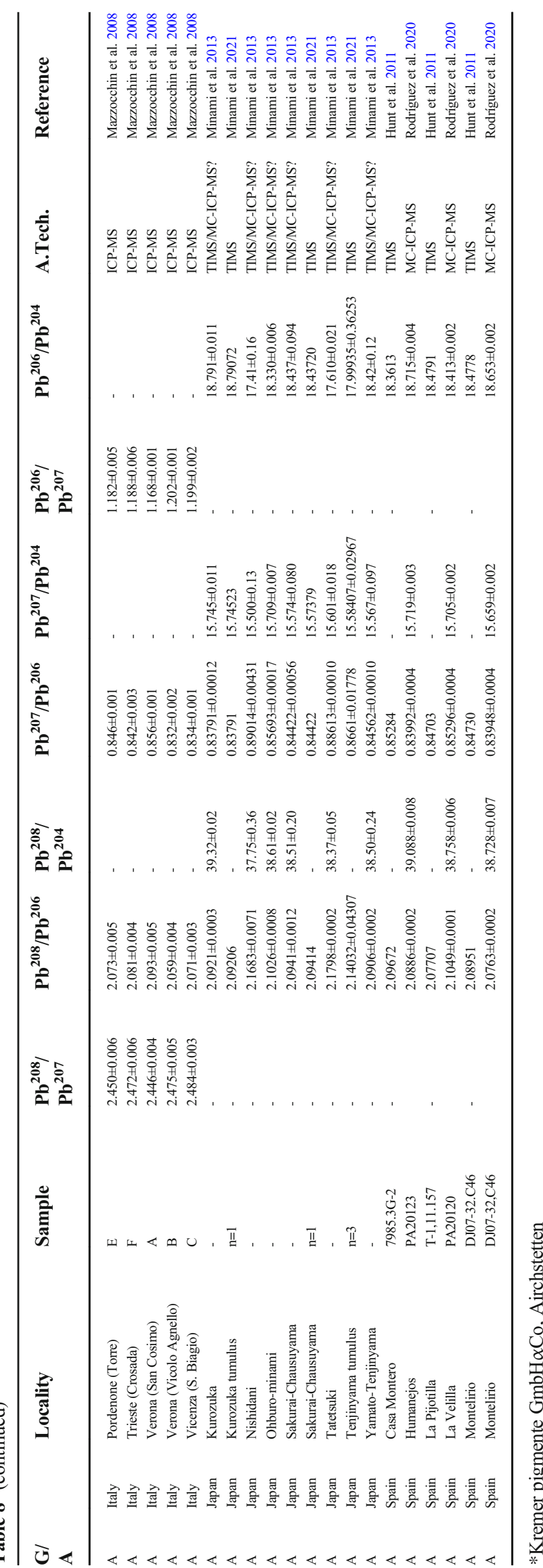

From these indications, it is possible to assign different values of precision to the proposed results. The reader must consider that, while the typical precision of TIMS is ca. $0.1 \%$ or better (Begemann et al. 1995) and the precision of MCICP-MS can reach $0.03 \%$ and better (Nørgaard et al. 2019), the quadrupole ICP-MS is not able to provide equally precise results. The latter remains at substantially lower precision $(0.1 \%$ ), often ranging between 0.2 and $0.5 \%$ (Gulson et al. 2018) and sometimes reaching even the percent range (Miśta-Jakubowska et al. 2019).

Lastly, mercury isotopes $\left({ }^{199} \mathrm{Hg},{ }^{200} \mathrm{Hg},{ }^{201} \mathrm{Hg},{ }^{202} \mathrm{Hg}\right)$ are perhaps the least used in archaeometry. Hintelmann and $\mathrm{Lu}$ (2003) demonstrated that different ratios of $\mathrm{Hg}$ isotopes might possibly discriminate cinnabar sources, although with some limits due to contamination. To the best of my knowledge, only Cooke et al. (2013), Prieto et al. (2016) ${ }^{16}$ and Minami et al. (2021) used mercury isotopes to investigate the use and trade of "archaeological" cinnabar. Conversely, data on natural cinnabar ores (and $\mathrm{Hg}_{\mathrm{L}}^{0}$ ) are also available for other areas such as Almaden $\left(\delta^{202} \mathrm{Hg}\right.$ ranging between -0.92 and $0.15 \%$, mean of $-0.56 \%, \sigma=0.35 \%, n=7$; Gray et al. 2013), Monte Amiata $\left(\delta^{202} \mathrm{Hg}\right.$ ranging between -0.96 and $-2.25 \%$, mean of $-1.34 \%, \sigma=0.5 \%, n=7$; Pribil et al. 2020) and a few Chinese and Japanese cinnabar ores (Minami et al. 2021).

Overall archaeometric investigations have shown that (a) it is possible to obtain significant results through isotopic analyses and (b) the investigated cinnabar ores are still few. Conversely, the database used for comparison should be large enough not to incur "false positives" or those cases in which provenance is assessed based on a non-representative ground for comparison.

\section{Concluding summary of key concepts}

Was cinnabar that rare and expensive?

The question may come to mind after such a long and geographically large list of occurrences.

Actually, this should be true only for antiquity, that is, when the use of cinnabar is attested in contexts related to kings, queens and wealthy families. Starting from about the $8^{\text {th }}-9^{\text {th }}$ centuries (before/after depending on the geographical area), the possibility of synthesising vermilion must have gradually lowered its cost.

The rarity of the raw material may undoubtedly have favoured its use in neighbouring regions or regions linked by political and commercial relations with the supply areas, such as Spain and Italy in Roman times. Still, it is too early to trace a diachronic and comprehensive picture of its distribution. On the cinnabar trade, we still have little data available, and, at the same time,

\footnotetext{
${ }^{16}$ Raw data not shown.
} 
the comparison database for provenance assessment is yet small whatever technique is to be used. The isotopic data are still few and cover only some deposits; therefore, much work is needed to reach a larger geographical area. If more effective techniques are not discovered, it would be advantageous to follow already traced paths, such as measuring sulphur and/or lead isotopes. There is already a database available that only needs to be expanded.

What is certain today is that cinnabar has been used to paint almost everything, from human bones to furnishings, from architectural surfaces to manuscripts, from lacquers to lustre. The problems related to fresco painting have been typically solved with the secco technique. The association with other organic and inorganic pigments such as madder lake or minium seems variously motivated. It may reflect a technical skill, aimed at conferring stability to the pigment and preventing the blackening, or it may represent a counterfeit aimed at increasing the weight of the powder to sell it at an even higher price than the declared one. With the use of cinnabar in lustre production, perhaps a sort of technological milestone is reached because cinnabar is no longer used for its beautiful red colour but as a functional additive to reduce copper.

The discoveries relating to the use of calomel as a pigment have opened a new field of investigation, closely related to the study of the degradation products into which cinnabar can transform. However, recent findings have also highlighted that an approximate, albeit quick and inexpensive analytical approach is no longer sufficient or acceptable.

Pending desirable future developments, we may still agree on what to call it. The distinction between natural cinnabar and synthetic vermilion has worked well for a long time, and it would therefore be helpful to keep it.

Supplementary Information The online version contains supplementary material available at https://doi.org/10.1007/s12520-021-01402-4.

Acknowledgements I would like to express my very great appreciation to Prof. E. Pernicka, who carefully revised the section focused on isotopic analyses, and to Dr. L. Burgio, who provided me with very valuable tips and advice for drafting the section on calomel. I also sincerely thank the two anonymous reviewers for the constructive feedback. Their comments and suggestions helped improve and clarify this manuscript. Jeff Weissman, Carlos Gonzalez Bargueño, Fabre Minerals and The Arkenstone are kindly acknowledged for allowing me to use the magnificent photos provided in Fig. 1.

\section{Author contribution Not applicable}

Funding Open access funding provided by Università degli Studi di Bari Aldo Moro within the CRUI-CARE Agreement.
Data Availability No new data were created or analysed in this study. The CC-BY licence does not supersede previously copyrighted material. The images provided in Figure 1 remain under owner's copyright.

Code availability Not applicable

\section{Declarations}

Competing interests The author declares no competing interests.

Open Access This article is licensed under a Creative Commons Attribution 4.0 International License, which permits use, sharing, adaptation, distribution and reproduction in any medium or format, as long as you give appropriate credit to the original author(s) and the source, provide a link to the Creative Commons licence, and indicate if changes were made. The images or other third party material in this article are included in the article's Creative Commons licence, unless indicated otherwise in a credit line to the material. If material is not included in the article's Creative Commons licence and your intended use is not permitted by statutory regulation or exceeds the permitted use, you will need to obtain permission directly from the copyright holder. To view a copy of this licence, visit http://creativecommons.org/licenses/by/4.0/.

\section{References}

Abdel-Ghani M, Edwards HGM, Stern B, Janaway R (2009) Characterization of paint and varnish on a medieval CopticByzantine icon: novel usage of dammar resin. Spectrochimica Acta - Part A: Molecular and Biomolecular Spectroscopy 73(3): 566-575. https://doi.org/10.1016/j.saa.2008.10.050

Abdel-Maksoud G, Ibrahim M, Issa YM, Magdy M (2020) Investigation of painting technique of Coptic icon by integrated analytical methods: imaging, spectroscopic and chemometric methods. $J$ Archaeol Sci Rep 29:102085. https://doi.org/10.1016/j.jasrep.2019. 102085

Aceto M (2021) The palette of organic colourants in wall paintings. Archaeol Anthropol Sci. https://doi.org/10.1007/s12520-02101392-3

Aceto M, Agostino A, Boccaleri E, Garlanda AC (2008) The Vercelli gospels laid open: an investigation into the inks used to write the oldest Gospels in Latin. X-Ray Spectrom 37(4):286-292. https://doi. org/10.1002/xrs.1047

Aceto M, Agostino A, Fenoglio G, Baraldi P, Zannini P, Hofmann C, Gamillscheg E (2012) First analytical evidences of precious colourants on Mediterranean illuminated manuscripts. Spectrochimica Acta - Part A: Molecular and Biomolecular Spectroscopy 95:235-245. https://doi.org/10.1016/j.saa.2012.04. 103

Ahn JY (2008) Zen and the art of nourishing life labor, exhaustion, and the malady of meditation. Jpn J Relig Stud 35(2):177-229. https:// doi.org/10.18874/jjrs.35.2.2008.117-229

Akçay Miğraç, Özkan H. Mustafa, Moon Charlie J., Spiro Baruch (2006) Geology, mineralogy and geochemistry of the gold-bearing stibnite and cinnabar deposits in the Emirli and Halıköy areas (Ödemiş, İzmir, West Turkey). Ore Geology Reviews 29(1):19-51. https:// doi.org/10.1016/j.oregeorev.2004.12.006

Akyuz T, Akyuz S, Gulec A (2015) Elemental and spectroscopic characterization of plasters from Fatih Mosque-Istanbul (Turkey) by combined micro-Raman, FTIR and EDXRF techniques. Spectrochimica Acta - Part A: Molecular and Biomolecular Spectroscopy 149:744750. https://doi.org/10.1016/j.saa.2015.05.015 
Aliatis I, Bersani D, Campani E, Casoli A, Lottici PP, Mantovan S, Marino I-G (2010) Pigments used in Roman wall paintings in the Vesuvian area. J Raman Spectrosc 41(11):1537-1542. https://doi. org/10.1002/jrs.2701

Anonymous (1967) Cinnabar with everything. Nature 213(5074):328 329. https://doi.org/10.1038/213328b0

Argote DL, Torres G, Hernández-Padrón G, Ortega V, López-García PA, Castaño VM (2020) Cinnabar, hematite and gypsum presence in mural paintings in Teotihuacan, Mexico. J Archaeol Sci Rep 32: 102375. https://doi.org/10.1016/j.jasrep.2020.102375

Arizzi A, Cultrone G (2021) Mortars and plasters - How to characterise hydraulic mortars. Archaeol Anthropol Sci. https://doi.org/10.1007/ s12520-021-01404-2

Arjonilla P, Domínguez-Vidal A, de la Torre López MJ, Rubio-Domene R, Ayora-Cañada MJ (2016) In situ Raman spectroscopic study of marble capitals in the Alhambra monumental ensemble. Appl Physics A: Mater Sci Proc 122(12):1014. https://doi.org/10.1007/ s00339-016-0537-2

Arjonilla P, Domínguez-Vidal A, Correa-Gómez E, Domene-Ruiz MJ, Ayora-Cañada MJ (2019a) Raman and Fourier transform infrared microspectroscopies reveal medieval Hispano-Muslim wood painting techniques and provide new insights into red lead production technology. J Raman Spectrosc 50(10):1537-1545. https://doi.org/ $10.1002 /$ jrs. 5660

Arjonilla P, Ayora-Cañada MJ, Rubio Domene R, Correa Gómez E, de la Torre-López MJ, Domínguez-Vidal A (2019b) Romantic restorations in the Alhambra monument: spectroscopic characterization of decorative plasterwork in the Royal Baths of Comares. $J$ Raman Spectrosc 50(2):184-192. https://doi.org/10.1002/jrs.5422

Arriaza B, Ogalde JP, Campos M, Paipa C, Leyton P, Lara N (2018) Toxic pigment in a Capacocha burial: instrumental identification of cinnabar in Inca human remains from Iquique, Chile. Archaeometry 60(6):1324-1333. https://doi.org/10.1111/arcm. 12392

Ashmore W (2015) Contingent acts of remembrance: royal ancestors of classic Maya Copan and Quirigua. Anc Mesoam 26(2):213-231. https://doi.org/10.1017/S095653611500019X

Auriemma R (Ed.) (2018) Nel mare dell'intimità. L'archeologia subacquea racconta l'Adriatico. Exhibition catalogue (Trieste, ex Pescheria-Salone degli Incanti, $17^{\text {th }}$ December $2017-1^{\text {st }}$ May 2018). Gangemi Editore.

Aurisicchio C, Ferro D, Martinelli G, Cesaro SN, Rapinesi IA (2002) A study of a distaff of the second century A.D. from a necropolis of Boccone D'Aste (Roma, Italy)-tomb 75. J Cult Herit 3(2):107-116. https://doi.org/10.1016/S1296-2074(02)01168-8

Auvray P, Genet F (1973) Affinement de la structure cristalline du cinabre $\alpha-\mathrm{HgS}$. Bulletin de la Societe Francaise de Mineralogie et de Cristallographie 96(3):218-219. https://doi.org/10.3406/bulmi. 1973.6816

Ávila A, Mansilla J, Bosch P, Pijoan C (2014) Cinnabar in Mesoamerica: poisoning or mortuary ritual? J Archaeol Sci 49(1):48-56. https:// doi.org/10.1016/j.jas.2014.04.024

Avlonitou L (2016) Pigments and colours: an inside look at the painted decoration of the Macedonian funerary monuments. J Archaeol Sci Rep 7:668-678. https://doi.org/10.1016/j.jasrep.2016.03.017

Bakiler M, Kirmizi B, Ormanci Öztürk Ö, Boso Hanyali Ö, Dağ E, Çağlar E, Köroğlu G (2016) Material characterization of the Late Roman wall painting samples from Sinop Balatlar Church Complex in the Black Sea region of Turkey. Microchem J 126:263-273. https://doi.org/10.1016/j.microc.2015.11.050

Ballirano P, Botticelli M, Maras A (2013) Thermal behaviour of cinnabar, $\alpha-\mathrm{HgS}$, and the kinetics of the $\beta-\mathrm{HgS}$ (metacinnabar) $\rightarrow \alpha-\mathrm{HgS}$ conversion at room temperature. Eur J Mineral 25(6):957-965. https://doi.org/10.1127/0935-1221/2013/0025-2341
Bao Y, Xu C, Zhu Q, Li Y (2019) A study on Chinese ancient jades with mercury alteration unearthed from Lizhou'ao Tomb. Sci Rep 9: 19849. https://doi.org/10.1038/s41598-019-55138-2

Barone G, Bersani D, Coccato A, Lauwers D, Mazzoleni P, Raneri S, Vandenabeele P, Manzini D, Agostino G, Neri NF (2016) Nondestructive Raman investigation on wall paintings at Sala Vaccarini in Catania (Sicily). Appl Physics A: Mater Sci Proc 122(9):838. https://doi.org/10.1007/s00339-016-0370-7

Barone G, Mazzoleni P, Cecchini A, Russo A (2018) In situ Raman and pXRF spectroscopic study on the wall paintings of Etruscan Tarquinia tombs. Dyes Pigments 150:390-403. https://doi.org/10. 1016/j.dyepig.2017.12.008

Barrios J, Gavilán B, Martínez MJ, Montealegre L (1999) Caracterización de cerámicas neolíticas procedentes de la cueva de los Murciélagos, Córdoba. In: Capel J (Ed.) Arqueometría y Arqueología. Monografia Arte y Arqueología. Granada, pp. 49-55.

Barrocas Dias C, Mirão J (2013) Identificação de pigmentos vermelhos recolhidos no hipogeu da sobreira de cima por microscopia de raman e microscopia electrónica de varrimento acoplada com espectroscopia de dispersão de energias de raios-X (MEV-EDX). In: Valera AC (Ed.) Sobreira de Cima - Necrópole de Hipogeus do Neolítico (Vidigueira, Beja). Era Monográfica, 1. Lisboa: Núcleo de Investigação Arqueológica - NIA, pp. 101-108.

Barroso MS (2013) Bezoar stones, magic, science and art. Geol Soc Lond, Spec Publ 375(1):193-207. https://doi.org/10.1144/SP375.11

Bascón-Mateos JM, Jabalquinto I, Tejedor García Ú (2016) El hallazgo de los restos parciales de una cueva artificial de enterramiento calcolítico en el yacimiento arqueológico de Getsemaní-Cerro del Ojo (Pedrera, Sevilla). SPAL: Revista de prehistoria y arqueología de la Universidad de Sevilla 25:227-251

Batta E, Argáez C, Mansilla J, Pijoan C, Bosch P (2013) On yellow and red pigmented bones found in Mayan burials of Jaina. $J$ Archaeol Sci 40(1):712-722. https://doi.org/10.1016/j.jas.2012.08.013

Béarat H (1996) Chemical and mineralogical analyses of Gallo-Roman wall painting from Dietikon, Switzerland. Archaeometry 38(1):8195. https://doi.org/10.1111/j.1475-4754.1996.tb00762.x

Becker H (2021) Pigment nomenclature in the ancient Near East, Greece, and Rome. Archaeol Anthropol Sci. https://doi.org/10.1007/s12520021-01394-1

Begemann F, Pernicka E, Schmitt-Strecker S (1995) Thermi on Lesbos: a case study of changing trade patterns. Oxf J Archaeol 14(2):123136. https://doi.org/10.1111/j.1468-0092.1995.tb00389.x

Bell EE, Sharer RJ, Traxler LP, Sedat DW, Carrelli CW, Grant LA (2004) Tombs and burials in the Early Classic Acropolis at Copan. In: Bell EE, Canuto MA, Sharer RJ (eds) Understanding Early Classic Copan. University of Pennsylvania Museum, Philadelphia, pp $131-158$

Bell AMT, Pattrick RAD, Vaughan DJ (2010) Structural evolution of aqueous mercury sulphide precipitates: energy-dispersive X-ray diffraction studies. Mineral Mag 74(1):85-96. https://doi.org/10.1180/ minmag.2010.074.1.85

Benedetti-Pichler AA (1937) Microchemical analysis of pigments used in the fossae of the incisions of Chinese oracle bones. Ind Eng Chem Anal Ed 9(3):149-152. https://doi.org/10.1021/ac50107a019

Berry LG, Thompson RM (1962) X-ray powder data for ore minerals: the Peacock atlas. Memoirs Geol Soc Am 85:69. https://doi.org/10.1130/ MEM85

Blasco-López FJ, Alejandre FJ, Flores-Alés V, Cortés I (2016) Plasterwork in the Ambassadors Hall (Salón de Embajadores) of the Real Alcázar of Seville (Spain): graphic reconstruction of polychrome work by layer characterization. Constr Build Mater 107: 332-340. https://doi.org/10.1016/j.conbuildmat.2016.01.021

Bonizzoni L, Bruni S, Galli A, Gargano M, Guglielmi V, Ludwig N, Lodi L, Martini M (2016) Non-invasive in situ analytical techniques working in synergy: the application on graduals held in the 
Certosa di Pavia. Microchem J 126:172-180. https://doi.org/10. 1016/j.microc.2015.12.001

Borhegyi SF (1959) Underwater archaeology in the Maya Highlands. Sci Am 200:100-113

Boschetti C, Corradi A, Baraldi P (2008) Raman characterization of painted mortar in Republican Roman mosaics. J Raman Spectrosc 39(8 SPEC. ISS):1085-1090. https://doi.org/10.1002/jrs.1970

Bösiger P (2019) Painted decorations on the Chinese and French lacquers of an eighteenth-century chest of drawers: when one runs over onto the other. Stud Conserv 64(S1):881-890. https://doi.org/10.1080/ 00393630.2018 .1563743

Botticelli M, Maras A, Candeias A (2020) $\mu$-Raman as a fundamental tool in the origin of natural or synthetic cinnabar: preliminary data. $J$ Raman Spectrosc 51(9):1470-1479. https://doi.org/10.1002/jrs. 5733

Bratu I, Paduraru M, Marutoiu C, Pop SSF, Kacso I, Tanaselia C, Marutoiu OF, Sandu ICA (2016) Multianalytical study on two wooden icons from the beginning of the eighteenth century evaluation of conservation state. Rev Chim 67(11):2383-2388

Briceño, E.M., Lazarich González, M., Feliu Ortega, M.J. (2012) Polvo rojo para los difuntos: La utilización de los ocres en la necrópolis Paraje de Monte Bajo (Alcala de los Gazules, Cádiz). In: Conjunto Arqueológico Dólmenes de Antequera (Ed.) Memorial Luis Siret - I Congreso de Prehistoria de Andalucía - La tutela del patrimonio prehistórico. Sevilla: Junta de Andalucía. Consejería de Cultura, pp. 587-590.

Brill RH, Wampler JM (1967) Isotope ratios in archaeological objects of lead. In: Museum of Fine Arts, Boston. Research Laboratory (Ed.) Proceedings of the seminar: Application of science in examination of works of art (Boston, September 7-16, 1965). Boston: Museum of Fine Arts, pp. 155-166.

Brocchieri J, de Viguerie L, Sabbarese C, Boyer M (2020) Combination of noninvasive imaging techniques to characterize pigments in Buddhist thangka paintings. X-Ray Spectrometry 50:320-331. https://doi.org/10.1002/xrs.3189

Brooks WE, Piminchumo V, Suárez H, Jackson JC, McGeehin JP (2008) Mineral pigments at Huaca Tacaynamo (Chan Chan, Peru). Bull de l'Institut français d'études andines 37(3):441-450. https://doi.org/ 10.4000/bifea.2957

Bruhns KO, Brooks WE, Truhan D (2017) Looking at a map might help: a comment on Burger et al., Ecuadorian cinnabar and the prehispanic trade in vermilion pigment: viable hypothesis or red herring? Lat Am Antiq 28(4):609-610. https://doi.org/10.1017/laq. 2017.46

Bruni S, Cariati F, Casadio F, Toniolo L (1999) Identification of pigments on a XV century illuminated parchment by Raman and FTIR microspectroscopies. Spectrochimica Acta - Part A: Molecular and Biomolecular Spectroscopy 55(7-8):1371-1377. https://doi. org/10.1016/S1386-1425(98)00300-X

Buckley H, Vernon W (1925) The crystal-structures of the sulphides of mercury. Mineral Mag 20(110):382-392

Bueno-Ramírez P, Barroso-Bermejo R, Balbín-Behrmann R (2019) Funerary red (cinnabar versus ochre) and megalithic rituals in the central Iberian peninsula. The hypogean necropolis of Valle de las Higueras, Huecas, Toledo Spain. Bulletin de la Societé Préhistorique Française 116(1):73-93

Burger RL, Leikin JB (2018) Cinnabar use in prehispanic Peru and its possible health consequences. J Archaeol Sci Rep 17:730-734. https://doi.org/10.1016/j.jasrep.2017.12.010

Burger RI, Lane KE, Cooke CA (2016) Ecuadorian cinnabar and the prehispanic trade in vermilion pigment: viable hypothesis or red herring? Lat Am Antiq 27(1):22-35. https://oi.org/10.7183/10456635.27.1.22

Burgio L (2021) Pigments, dyes and inks - their analysis on manuscripts, scrolls and papyri. Archaeol Anthropol Sci. https://doi.org/10.1007/ s12520-021-01403-3
Burgio L, Clark RJH, Gibbs PJ (1999) Pigment identification studies in situ of Javanese, Thai, Korean, Chinese and Uighur manuscripts by Raman microscopy. J Raman Spectrosc 30(3):181-184.

Burgio L, Melchar D, Strekopytov S, Peggie DA, Melchiorre Di Crescenzo M, Keneghan B, Najorka J, Goral T, Garbout A, Clark BL (2018) Identification, characterisation and mapping of calomel as 'mercury white', a previously undocumented pigment from South America, and its use on a barniz de Pasto cabinet at the Victoria and Albert Museum. Microchem J 143:220-227. https://doi.org/10. 1016/j.microc.2018.08.010

Burkstaller JE, McCarty PL, Parks GA (1975) Oxidation of cinnabar by $\mathrm{Fe}(\mathrm{III})$ in acid mine waters. Environ Sci Technol 9(7):676-678. https://doi.org/10.1021/es60105a004

Caiger Smith A (1985) Lustre pottery. Technique, tradition and innovation in Islam and the Western World. Gentle Breeze Pub Co, London, p 246

Calà E, Agostino A, Fenoglio G, Capra V, Porticelli F, Manzari F, Fiddyment S, Aceto M (2019) The Messale Rosselli: scientific investigation on an outstanding $14^{\text {th }}$ century illuminated manuscript from Avignon. J Archaeol Sci Rep 23:721-730. https://doi.org/10. 1016/j.jasrep.2018.12.001

Calamiotou M., Siganidou M., Filippakis S. E. (2013) X-ray analysis of pigments from Pella, Greece. Studies in Conservation 28(3):117121. https://doi.org/10.1179/sic.1983.28.3.117

Caley ER, Richards JF (1956) Theophrastus on stones. Ohio State University Press, Columbus, p 238

Calos NJ, Kennard CHL, Davis RL (1989) The structure of calomel, $\mathrm{Hg}_{2} \mathrm{Cl}_{2}$, derived from neutron powder data. Z Krist 187(3-4):305307. https://doi.org/10.1524/zkri.1989.187.3-4.305

Campos EMP, Muñoz AJH (2013) Mines and miners: metals in sediments and human remains from southern sierra Gorda, Querétaro, Mexico [Minas y mineros: Presencia de metales en sedimentos y restos humanos al sur de la sierra gorda de querétaro en méxico]. Chungara 45(1):161-176. https://doi.org/10.4067/S071773562013000100008

Çamurcuoğlu, D.S. (2015) The wall paintings of Çatalhöyük (Turkey): materials, technologies and artists. PhD Thesis submitted to University College London, Institute of Archaeology University College, London, pp. 280.

Cardell C, Rodríguez-Simon L, Guerra I, Sanchez-Navas A (2009) Analysis of Nasrid polychrome carpentry at the Hall of the Mexuar Palace, Alhambra complex (Granada, Spain), combining microscopic, chromatographic and spectroscopic methods. Archaeometry 51(4):637-657. https://doi.org/10.1111/j.1475-4754. 2008.00438.x

Cardell-Fernández C, Navarrete-Aguilera C (2006) Pigment and plasterwork analyses of Nasrid polychromed Lacework stucco in the Alhambra (Granada, Spain). Stud Conserv 51(3):161-176. https:// doi.org/10.1179/sic.2006.51.3.161

Carlsen RS (1986) Analysis of the early classic period textile remains, tomb 19, Rio Azul, Guatemala. In: Adams REW (Ed.) Rio Azul reports, number 2: the 1984 season. San Antonio: Center for Archaeological Research, University of Texas, pp. 122-155.

Carlsen RS (1987) Analysis of the Early Classic Period textile remains: tomb 23, Rio Azul, Guatemala. In: Adams REW (Ed.) Rio Azul reports, number 3: the 1985 season. San Antonio: Center for Archaeological Research, University of Texas, pp. 152-160.

Caroselli M, Ruffolo SA, Piqué F (2021) Mortars and plasters - How to manage mortars and plasters conservation. Archaeol Anthropol Sci. https://doi.org/10.1007/s12520-021-01409-x

Carter T (2008) Cinnabar and the cyclades: body modification and political structure in the Late EBI Southern Aegean. In: Erkanal H, Hauptmann H, Șahoğlu V, Tuncel R (eds) The Aegean in the Neolithic, Chalcolithic and Early Bronze Age. Ankara University Press, Ankara, pp 119-131 
Carter AK, Dussubieux L, Beavan N (2016) Glass beads from $15^{\text {th }}-17^{\text {th }}$ century CE jar burial sites in Cambodia's Cardamom Mountains. Archaeometry 58:401-412. https://doi.org/10.1111/arcm.12183

Carvalho I, Casanova C, Araújo R, Lemos A (2018) Colour identification, degradation processes and findings in a fifteenth-century Book of Hours: the case study of Cofre.$^{\circ} 31$ from Mafra National Palace. Heritage. Science 6(1):9. https://doi.org/10.1186/s40494-018-01745

Castro K, Pessanha S, Proietti N, Princi E, Capitani D, Carvalho ML, Madariaga JM (2008) Noninvasive and nondestructive NMR, Raman and XRF analysis of a Blaeu coloured map from the seventeenth century. Anal Bioanal Chem 391(1):433-441. https://doi.org/ 10.1007/s00216-008-2001-4

Cavallo G, Riccardi MP (2021) Glass-based pigments in painting. Archaeol Anthropol Sci (forthcoming). https://doi.org/10.1007/ s12520-021-01453-7

Cepriá G, Roque J, Molera J, Pérez-Arantegui J, Vendrell M (2007) Electroanalytical study of the composition of the raw pigment mixtures that yield the metallic lustre on ceramics. A link between composition and final result. Electroanalysis 19(11):1167-1176. https:// doi.org/10.1002/elan.200603818

Cerrato EJ, Cosano D, Esquivel D, Jiménez-Sanchidrián C, Ruiz JR (2020) A multi-analytical study of funerary wall paintings in the Roman necropolis of Camino Viejo de Almodóvar (Córdoba, Spain). Eur Physical J Plus 135(11):889. https://doi.org/10.1140/ epjp/s13360-020-00908-5

Cervini-Silva J, Palacios E, Muñóz ML, Paz del Angel P, Montoya JA, Ramos E, López F, Romano Pacheco A (2013) Cinnabar-preserved bone structures from primary osteogenesis and fungal signatures in ancient human remains. Geomicrobiol J 30(7):566-577. https://doi. org/10.1080/01490451.2012.737090

Cervini-Silva J, Muñoz MDL, Palacios E, Jimenez-Lopez JC, RomanoPacheco A (2018) Ageing and preservation of HgS-enriched ancient human remains deposited in confinement. J Archaeol Sci Rep 18: 562-567. https://doi.org/10.1016/j.jasrep.2018.02.010

Cesareo R, Bustamante A, Fabian J, Calza C, Dos Anjos M, Lopes RT, Elera C, Shimada I, Curay V, Rizzutto MA (2010) Energydispersive $\mathrm{X}$-ray fluorescence analysis of a pre-Columbian funerary gold mask from the Museum of Sicán, Peru. X-Ray Spectrom 39(2): 122-126. https://doi.org/10.1002/xrs.1192

Chaplin TD, Clark RJH, Jacobs D, Jensen K, Smith GD (2005) The Gutenberg Bibles: analysis of the illuminations and inks using Raman spectroscopy. Anal Chem 77(11):3611-3622. https://doi. org/10.1021/ac050346y

Chaplin TD, Clark RJH, McKay A, Pugh S (2006) Raman spectroscopic analysis of selected astronomical and cartographic folios from the early 13th century Islamic 'Book of Curiosities of the Sciences and Marvels for the Eyes'. J Raman Spectrosc 37(8):865-877. https:// doi.org/10.1002/jrs. 1536

Cheilakou E, Troullinos M, Koui M (2014) Identification of pigments on Byzantine wall paintings from Crete (14th century AD) using noninvasive fiber optics diffuse reflectance spectroscopy (FORS). $J$ Archaeol Sci 41:541-555. https://doi.org/10.1016/j.jas.2013.09.020

Chen Y, Yin Y, Shi J, Liu G, Hu L, Liu J, Cai Y, Jiang G (2017) Analytical methods, formation, and dissolution of cinnabar and its impact on environmental cycle of mercury. Crit Rev Environ Sci Technol 47(24):2415-2447. https://doi.org/10.1080/10643389. 2018.1429764

Chen E, Zhang B, Zhao F, Wang C (2019) Pigments and binding media of polychrome relics from the central hall of Longju temple in Sichuan, China. Heritage Sci 7(1):45. https://doi.org/10.1186/ s40494-019-0289-3

Cheung KA, Xie N, Yao Z, Houston S, Newman S, Román-Ramírez ER, Garrison T, Fischer C, Muros V, Prikhodko S, Kakoulli I (2013) Analysis of samples excavated from a royal tomb in El Zotz: application of materials science characterization techniques in archaeology. ACS Symp Ser 1147:397-418. https://doi.org/10. 1021/bk-2013-1147.ch021

Chiavari G, Mazzeo R (1999) Characterisation of paint layers in Chinese archaelogical relics by pyrolysis-GC-MS. Chromatographia 49(56):268-272. https://doi.org/10.1007/BF02467555

Childe VG (1957) The dawn of European civilisation. Routledge \& Kegan, London

Clark RJH, Gibbs PJ (1997) Identification of lead(II) sulfide and pararealgar on a $13^{\text {th }}$ century manuscript by Raman microscopy. Chem Commun 11:1003-1004. https://doi.org/10.1039/a701837a

Clark RJH, Gibbs PJ (1998) Peer reviewed: Raman microscopy of a $13^{\text {th }}$ century illuminated text. Anal Chem 70(3):99A-104A. https://doi. org/10.1021/ac981719g

Clark RJH, Van Der Weerd J (2004) Identification of pigments and gemstones on the Tours Gospel: the early $9^{\text {th }}$ century Carolingian palette. J Raman Spectrosc 35(4):279-283. https://doi.org/10.1002/jrs.1148

Clark RJH, Gibbs PJ, Seddon KR, Brovenko NM, Petrosyan YA (1997) Non-destructive in situ identification of cinnabar on ancient Chinese manuscripts. J Raman Spectrosc 28(2-3):91-94.

Clementi C, Ciocan V, Vagnini M, Doherty B, Laurenzi Tabasso M, Conti C, Brunetti B, Miliani C (2011) Non-invasive and microdestructive investigation of the Domus Aurea wall painting decorations. Anal Bioanal Chem 401:1815-1826. https://doi.org/10.1007/ s00216-011-5250-6

Colomban P, Mancini D (2013) Lacquerware pigment identification with fixed and mobile Raman microspectrometers: a potential technique to differentiate original/fake artworks. Arts 2(3):111-123. https:// doi.org/10.3390/arts2030111

Cooke CA, Hintelmann H, Ague JJ, Burger R, Biester H, Sachs JP, Engstrom DR (2013) Use and legacy of mercury in the Andes. Environ Sci Technol 47(9):4181-4188. https://doi.org/10.1021/ es3048027

Corso G, Gelzo M, Chambery A, Severino V, Di Maro A, Lomoriello FS, D'Apolito O, Russo AD, Gargiulo P, Piccioli C, Arcari P (2012) Characterization of pigments and ligands in a wall painting fragment from Liternum archaeological park (Italy). J Sep Sci 35(21):29862993. https://doi.org/10.1002/jssc.201200490

Costantini I, Lottici PP, Bersani D, Pontiroli D, Casoli A, Castro K, Madariaga JM (2020) Darkening of lead- and iron-based pigments on late Gothic Italian wall paintings: energy dispersive X-ray fluorescence, $\mu$-Raman, and powder X-ray diffraction analyses for diagnosis: presence of $\beta-\mathrm{PbO}_{2}$ (plattnerite) and $\alpha-\mathrm{PbO}_{2}$ (scrutinyite). J Raman Spectrosc 51(4):680-692. https://doi.org/10.1002/jrs.5817

Cotte M, Susini J, Metrich N, Moscato A, Gratziu C, Bertagnini A, Pagano M (2006) Blackening of Pompeian cinnabar paintings: Xray microspectroscopy analysis. Anal Chem 78(21):7484-7492. https://doi.org/10.1021/ac0612224

Couoh LR (2015) Bioarchaeological analysis of a royal burial from the oldest Maya Tomb in Palenque, Mexico. Int J Osteoarchaeol 25(5): 711-721. https://doi.org/10.1002/oa.2338

Crippa M, Legnaioli S, Kimbriel C, Ricciardi P (2020) New evidence for the intentional use of calomel as a white pigment. J Raman Spectrosc 52:15-22. https://doi.org/10.1002/jrs.5876

Damiani D, Gliozzo E, Turbanti IM, Spangenberg JE (2003) Pigments and plasters discovered in the House of Diana (Cosa, Grosseto, Italy): an integrated study between art history, archaeology and scientific analyses. Archaeometry 45(2):341-354. https://doi.org/10. 1111/1475-4754.00112

Damiani D, Gliozzo E, Turbanti Memmi I (2014) The 'Madonna and Child Enthroned with Saints' of Ambrogio Lorenzetti in the St. Augustine Church (Siena, Italy): Raman microspectroscopy and SEM-EDS characterisation of the pigments. Archaeol AnthropolSci 6:363-371. https://doi.org/10.1007/s12520-014-0175-6

Daniilia S, Andrikopoulos KS (2007) Issues relating to the common origin of two Byzantine miniatures: In situ examination with 
Raman spectroscopy and optical microscopy. J Raman Spectrosc 38(3):332-343. https://doi.org/10.1002/jrs.1648

Daniilia S, Minopoulou E (2009) A study of smalt and red lead discolouration in Antiphonitis wall paintings in Cyprus. Appl Physics A: Mater Sci Proc 96(3):701-711. https://doi.org/10.1007/ s00339-009-5163-9

Daniilia S, Sotiropoulou S, Bikiaris D, Salpistis C, Karagiannis G, Chryssoulakis Y, Price BA, Carlson JHP (2000) Panselinos' Byzantine wall paintings in the Protaton church, Mount Athos, Greece: a technical examination. $J$ Cult Herit 1:91-110. https:// doi.org/10.1016/S1296-2074(00)00164-3

Daniilia S, Bikiaris D, Burgio L, Gavala P, Clark RJH, Chryssoulakis Y (2002) An extensive non-destructive and micro-spectroscopic study of two post-Byzantine overpainted icons of the $16^{\text {th }}$ century. $J$ Raman Spectrosc 33(10):807-814. https://doi.org/10.1002/jrs.907

Daniilia S, Minopoulou E, Demosthenous FD, Karagiannis G (2008a) A comparative study of wall paintings at the Cypriot monastery of Christ Antiphonitis: one artist or two? J Archaeol Sci 35(6):16951707. https://doi.org/10.1016/j.jas.2007.11.011

Daniilia S, Minopoulou E, Andrikopoulos KS, Tsakalof A, Bairachtari K (2008b) From Byzantine to post-Byzantine art: the painting technique of St Stephen's wall paintings at Meteora, Greece. J Archaeol Sci 35(9):2474-2485. https://doi.org/10.1016/j.jas.2008.03.017

Degano I, Colombini MP (2009) Multi-analytical techniques for the study of pre-Columbian mummies and related funerary materials. $J$ Archaeol Sci 36(8):1783-1790. https://doi.org/10.1016/j.jas.2009. 04.015

DeLaine J (2021) Production, transport and on-site organisation of Roman mortars and plasters. Archaeol Anthropol Sci. https://doi. org/10.1007/s12520-021-01401-5

Dias L, Oliveira J, Rocha L, Rosado L, Dias C, Ferreira T, Candeias A, Mirao J (2011) Sobre a presença de Cinábrio em rituais funerários no Megalitismo do Alentejo, Portugal. In: IX Congresso Ibérico de Arqueometria, Poster. (Lisboa, 26-28 October 2011). Lisboa, pp. 93.

Dickson FW, Tunell G (1954) The saturation curves of cinnabar and metacinnabar in the system $\mathrm{HgS}-\mathrm{Na}_{2} \mathrm{~S}-\mathrm{H}_{2} \mathrm{O}$ at $25^{\circ} \mathrm{C}$. Science 119(3093):467-468. https://doi.org/10.1126/science.119.3093.467

Dickson FW, Tunell G (1959) The stability relations of cinnabar and metacinnabar. Am Mineral 44(5):471-487

Dinu M, Cortea IM, Ghervase L, Stancu MC, Mohanu I, Cristea N (2020) Optoelectronic investigation of the mural paintings from Drăguțești wooden church, Argeș County, Romania. J Optoelectron Adv Mater 22(5-6):303-309

Divers E (1894) The manufacture of calomel in Japan. Am J Pharm 18351907:232-243

Doherty C (2011) Clay and landscape studies. Çatalhöyük Arch Rep 2011:90-94

Doleżyńska-Sewerniak E, Jendrzejewski R, Klisińska-Kopacz A, Sawczak M (2020) Non-invasive spectroscopic methods for the identification of drawing materials used in XVIII century. J Cult Herit 41:34-42. https://doi.org/10.1016/j.culher.2019.07.008

Domingo Sanz I, Chieli A (2021) Characterising the pigments and paints of prehistoric artists. Archaeol Anthropol Sci. https://doi.org/10. 1007/s12520-021-01397-y

Domingo I, García-Borja P, Roldán C (2012) Identification, processing and use of red pigments (hematite and cinnabar) in the Valencian early Neolithic (Spain). Archaeometry 54(5):868-892. https://doi. org/10.1111/j.1475-4754.2011.00650.x

Domínguez-Bella S (2010) Aplicaciones de las técnicas experimentales y la mineralogía a la arqueometría. Los pigmentos de cinabrio del dolmen de Alberite I, Villamartín (Cádiz). In: Domínguez-Bella S, Ramos Muñoz J, Gutiérrez López JM, Pérez Rodríguez M (eds) Minerales y rocas en las sociedades de la prehistoria. Universidad de Cádiz, Cádiz, pp 235-244
Domínguez-Bella S, Morata Céspedes D (1995) Aplicación de las técnicas mineralógicas y petrológicas a la arqueometría. Estudio de materiales del dolmen de Alberite (Villamartín, Cádiz). Zephyrus 48:129-142

Dominguez-Vidal A, De La Torre-Lopez MJ, Rubio-Domene R, AyoraCañada MJ (2012) In situ noninvasive Raman microspectroscopic investigation of polychrome plasterworks in the Alhambra. Analyst 137(24):5763-5769. https://doi.org/10.1039/c2an36027f

Dominguez-Vidal A, De La Torre-López MJ, Campos-Suñol MJ, RubioDomene R, Ayora-Cañada MJ (2014) Decorated plasterwork in the Alhambra investigated by Raman spectroscopy: comparative field and laboratory study. J Raman Spectrosc 45(11-12):1006-1012. https://doi.org/10.1002/jrs.4439

Dorm E (1971) Intermetallic distances in mercury(I) Halides $\mathrm{Hg}_{2} \mathrm{~F}_{2}$, $\mathrm{Hg}_{2} \mathrm{Cl}_{2}$ and $\mathrm{Hg}_{2} \mathrm{Br}_{2}$. Chem Commun:466-467

Dreyer RM (1940a) The geochemistry of quicksilver mineralization. Econ Geol 35(1):17-48. https://doi.org/10.2113/gsecongeo.35.1.17

Dreyer RM (1940b) The geochemistry of quicksilver mineralization. II Petrographic aspects of the geochemistry of quicksilver mineralization. Econ Geol 35(2):140-157. https://doi.org/10.2113/gsecongeo. 35.2 .140

Duce C, Ghezzi L, Onor M, Bonaduce I, Colombini MP, Tine MR, Bramanti E (2012) Physico-chemical characterization of proteinpigment interactions in tempera paint reconstructions: casein/ cinnabar and albumin/cinnabar. Anal Bioanal Chem 402(6):21832193. https://doi.org/10.1007/s00216-011-5684-x

Dunning GE, Hadley TA, Magnasco J, Christy AG, Cooper JF Jr (2005) The Clear Creek mine, San Benito County, California: a unique mercury locality. Mineral Rec 36(4):337-363

Durán A, Pérez-Rodríguez JL, Espejo T, Franquelo ML, Castaing J, Walter P (2009) Characterization of illuminated manuscripts by laboratory-made portable XRD and micro-XRD systems. Anal Bioanal Chem 395(7):1997-2004. https://doi.org/10.1007/s00216009-2992-5

Durán A, Jimenez De Haro MC, Pérez-Rodríguez JL, Franquelo ML, Herrera LK, Justo A (2010a) Determination of pigments and binders in Pompeian Wall paintings using synchrotron radiation - high-resolution X-ray powder diffraction and conventional spectroscopy chromatography. Archaeometry 52(2):286-307. https://doi.org/10. 1111/j.1475-4754.2009.00478.x

Durán A, Castaing J, Walter P (2010b) X-ray diffraction studies of Pompeian wall paintings using synchrotron radiation and dedicated laboratory made systems. Appl Physics A: Mater Sci Proc 99(2): 333-340. https://doi.org/10.1007/s00339-010-5625-0

Durán A, López-Montes A, Castaing J, Espejo T (2014) Analysis of a royal $15^{\text {th }}$ century illuminated parchment using a portable XRFXRD system and micro-invasive techniques. J Archaeol Sci 45(1): 52-58. https://doi.org/10.1016/j.jas.2014.02.011

Durán-Benito A, Herrera-Quintero LK, Robador-González MD, PérezRodríguez JL (2007) Color study of Mudejar paintings of the pond found in the Palace of "Reales Alcazares" in Seville. Color Res Appl 32(6):489-495. https://doi.org/10.1002/col.20351

Eastaugh, N., Walsh, V., Chaplin, T., Siddall, R. (2004) Pigment compendium: a dictionary and optical microscopy of historic pigments. Elsevier - Butterworth Heinemen, pp. 499.

Edwards HGM, Farwell DW, Newton EM, Perez FR (1999a) Minium; FT-Raman non-destructive analysis applied to an historical controversy. Analyst 124(9):1323-1326. https://doi.org/10.1039/ a904083h

Edwards HGM, Farwell DW, Rozenberg S (1999b) Raman spectroscopic study of red pigment and fresco fragments from King Herod's Palace at Jericho. J Raman Spectrosc 30(5):361-366.

Edwards HGM, Farwell DW, Rull Perez F, Jorge Villar S (1999c) Spanish mediaeval frescoes at Basconcillos del Tozo: a fourier transform Raman spectroscopic study. J Raman Spectrosc 30(4):307311. 
Edwards HGM, Rull F, Vandenabeele P, Newton EM, Moens L, Medina J, Garcia C (2001) Mediaeval pigments in the monastery of San Baudelio, Spain: a Raman spectroscopic analysis. Appl Spectrosc 55(1):71-76. https://doi.org/10.1366/0003702011951272

Edwards HGM, Farwell DW, Lee JS, Fredericks PM (2003) Vibrational spectroscopic study of the contents of a chest excavated from the wreck of the HMS Pandora. Spectrochimica Acta - Part A: Molecular and Biomolecular Spectroscopy 59(10):2311-2319. https://doi.org/10.1016/S1386-1425(03)00074-X

Edwards HGM, Farwell DW, Brooke CJ (2005) Raman spectroscopic study of a post-medieval wall painting in need of conservation. Anal Bioanal Chem 383(2):312-321. https://doi.org/10.1007/s00216005-0012-y

Edwards HGM, Newton EM, O'Connor S, Evans D (2010) FT-Raman spectroscopic analysis of pigments from an Augustinian friary. Anal Bioanal Chem 397:2685-2691. https://doi.org/10.1007/s00216010-3568-0

Egel E, Simon S (2013) Investigation of the painting materials in Zhongshan Grottoes (Shaanxi, China). Heritage Sci 1:29. https:// doi.org/10.1186/2050-7445-1-29

Elert K, Cardell C (2019) Weathering behavior of cinnabar-based tempera paints upon natural and accelerated aging. Spectrochimica Acta - Part A: Molecular and Biomolecular Spectroscopy 216:236-248. https://doi.org/10.1016/j.saa.2019.03.027

Emslie SD, Brasso R, Patterson WP, Carlos Valera A, McKenzie A, Maria Silva A, Gleason JD, Blum JD (2015) Chronic mercury exposure in Late Neolithic/Chalcolithic populations in Portugal from the cultural use of cinnabar. Sci Rep 5:14679. https://doi.org/10. 1038/srep14679

Emslie SD, Alderman A, McKenzie A, Brasso R, Taylor AR, Molina Moreno M, Cambra-Moo O, Gonzalez Martin A, Silva AM, Valera A, Garcia Sanjuan L, Vijande Vila E (2019) Mercury in archaeological human bone: biogenic or diagenetic? J Archaeol Sci 108: 104969. https://doi.org/10.1016/j.jas.2019.05.005

Erd RC, Roberts AC, Bonardi M, Criddle AJ, Le Page Y, Gabe EJ (1993) Edoylerite, $\mathrm{Hg}_{3}{ }^{2+} \mathrm{Cr}^{6+} \mathrm{O}_{4} \mathrm{~S}_{2}$ a new mineral from the Clear Creek claim, San Benito County, California. Mineral Rec 24(6):471-475

Ergenç D, Fort R, Varas-Muriel MJ, Alvarez de Buergo M (2021) Mortars and plasters - How to characterise aerial mortars and plasters. Archaeol Anthropol Sci. https://doi.org/10.1007/s12520-02101398-x

Espejo Arias T, López Montes A, García Bueno A, Durán Benito A, Blanc García R (2008) A study about colourants in the Arabic manuscript collection of the Sacromonte Abbey, Granada, Spain. A new methodology for chemical analysis. Restaurator 29(2):76-106. https://doi.org/10.1515/rest.2008.005

Fanti G, Zagotto G (2017) Blood reinforced by pigments in the reddish stains of the Turin Shroud. J Cult Herit 25:113-120. https://doi.org/ 10.1016/j.culher.2016.12.012

Fermo P, Padeletti G (2012) The use of nano-particles to produce iridescent metallic effects on ancient ceramic objects. J Nanosci Nanotechnol 12(11):8764-8769. https://doi.org/10.1166/jnn.2012. 6464

Fermo P, Piazzalunga A, De Vos M, Andreoli M (2013) A multianalytical approach for the study of the pigments used in the wall paintings from a building complex on the Caelian Hill (Rome). Appl Physics A: Mater Sci Proc 113(4):1109-1119. https://doi.org/10. 1007/s00339-013-7754-8

Fernández Flores Á, García Sanjuán L, Díaz-Zorita Bonilla M (2016) (Ed.) Montelirio: un gran Monumento Megalítico de la Edad del Cobre. Junta de Andalucia. Consejería de Cultura

Fikri I, El Amraoui M, Haddad M, Ettahiri AS, Bellot-Gurlet L, Falguères C, Lebon M, Nespoulet R, Ait Lyazidi S, Bejjit L (2018) XRF and UV-Vis-NIR analyses of medieval wall paintings of al-Qarawiyyin Mosque (Morocco). IOP Conf Series: Materials Science and
Engineering 353(1):012020. https://doi.org/10.1088/1757-899X/ $353 / 1 / 012020$

Filippakis SE, Perdikatsis B, Assimenos K (1979) X-Ray analysis of pigments from Vergina, Greece (Second Tomb). Stud Conserv 24(2):54-58

Fioretti G, Raneri S, Pinto D, Mignozzi M, Mauro D (2020) The archaeological site of St. Maria Veterana (Triggiano, Southern Italy): archaeometric study of the wall paintings for the historical reconstruction. J Archaeol Sci Rep 29:102080. https://doi.org/10.1016/j. jasrep.2019.102080

Fiorillo F, Fiorentino S, Montanari M, Roversi Monaco C, Del Bianco A, Vandini M (2020) Learning from the past, intervening in the present: the role of conservation science in the challenging restoration of the wall painting Marriage at Cana by Luca Longhi (Ravenna, Italy). Heritage Sci 8(1):10. https://doi.org/10.1186/s40494-020-0354-y

Fitzsimmons JL (2009) Death and the Classic Maya Kings. University of Texas Press, Austin

Fostiridou A, Karapanagiotis I, Vivdenko S, Lampakis D, Mantzouris D, Achilara L, Manoudis P (2016) Identification of pigments in Hellenistic and Roman funeral figurines. Archaeometry 58(3): 453-464. https://doi.org/10.1111/arcm.12177

Frade JC, Ribeiro MI, Graça J, Rodrigues J (2009) Applying pyrolysisgas chromatography/mass spectrometry to the identification of oriental lacquers: study of two lacquered shields. Anal Bioanal Chem 395:2167-2174. https://doi.org/10.1007/s00216-009-3043-y

Franceschi CM, Franceschi E, Nole D, Vassallo S, Glozheni L (2011) Two Byzantine Albanian icons: a non-destructive archaeometric study. Archaeol Anthropol Sci 3(4):343-355. https://doi.org/10. 1007/s12520-011-0073-0

Franquelo ML, Pérez-Rodríguez JL (2016) A new approach to the determination of the synthetic or natural origin of red pigments through spectroscopic analysis. Spectrochimica Acta - Part A: Molecular and Biomolecular Spectroscopy 166:103-111. https://doi.org/10. 1016/j.saa.2016.04.054

Fu S-H, Gu X-X, Wang P (2002) Characteristics of the gold-bearing minerals and their significance to the ore genesis of the Manaoke gold deposit, northwestern Sichuan. J Chengdu Instit Technol 29(4): 422-427

Fu Peng, Teri Ge-Le, Li Jing, Li Jia-Xin, Li Yu-Hu, Yang Hong (2020) Investigation of Ancient Architectural Painting from the Taidong Tomb in the Western Qing Tombs, Hebei, China. Coatings 10(7): 688. https://doi.org/10.3390/coatings10070688

Gajić-Kvaščev M, Stojanović MM, Šmit Z, Kantarelou V, Karydas AG, Šljivar D, Milovanović D, Andrić V (2012) New evidence for the use of cinnabar as a colouring pigment in the Vinča culture. $J$ Archaeol Sci 39(4):1025-1033. https://doi.org/10.1016/j.jas.2011. 11.023

Gale NH, Stos-Gale ZA (1982) Bronze Age copper sources in the Mediterranean: a new approach. Science 216(4541):11-19. https:// doi.org/10.1126/science.216.4541.11

García-Alix A, Minwer-Barakat R, Martín Suárez E, Freudenthal M, Delgado Huertas A (2013) Cinnabar mineralization in fossil small mammal remains as a consequence of diagenetic processes. Lethaia 46(1):1-6. https://doi.org/10.1111/let.12003

García-Moreno R, Granados J (2000) Tumbas reales de Calakmul. Arqueol Mexicana 42:28-33

Gard FS, Santos DM, Daizo MB, Mijares JL, Bozzano PB, Danón CA, Reinoso M, Halac EB (2020a) A noninvasive complementary study of an Egyptian polychrome cartonnage pigments using SEM, EPMA, and Raman spectroscopy. Surf Interface Anal 52(11):755769. https://doi.org/10.1002/sia.6866

Gard FS, Santos DM, Daizo MB, Freire E, Reinoso M, Halac EB (2020b) Pigments analysis of an Egyptian cartonnage by means of XPS and Raman spectroscopy. Appl Physics A: Mater Sci Proc 126(3):218. https://doi.org/10.1007/s00339-020-3386-y 
Garrote MA, Robador MD, Pérez-Rodríguez JL (2017) Analytical investigation of Mudéjar polychrome on the carpentry in the Casa de Pilatos palace in Seville using non-destructive XRF and complementary techniques. Spectrochimica Acta - Part A: Molecular and Biomolecular Spectroscopy 173:279-291. https://doi.org/10.1016/j. saa.2016.09.027

Gavilán B (1987) Excavación Arqueológica de Urgencia en el Dolmen de Las Casas de Don Pedro (Belmez, Córdoba). Anuario arqueológico de Andalucía 3:118-120

Gavilán B, Vera JC, 2004. Excavación Arqueológica (I.A.U. de apoyo a la restauración) en el Dolmen de Las Casas de Don Pedro (Belmez, Córdoba). In: Anuario arqueológico de Andalucía 2001, vol. 3. Junta de Andalucía, Sevilla, pp. 291-296.

Gazzola J (2009) Uso de cinabrio en la pintura mural de Teotihuacán. Arqueología 40:57-60

Gebremariam KF, Kvittingen L, Banica F-G (2013) Application of a portable XRF analyzer to investigate the medieval wall paintings of Yemrehanna Krestos church, Ethiopia. X-Ray Spectrom 42(6): 462-469. https://doi.org/10.1002/xrs.2504

Gebremariam KF, Kvittingen L, Nicholson DG (2016) Multi-analytical investigation into painting materials and techniques: the wall paintings of Abuna Yemata Guh church. Heritage Sci 4(1):32. https://doi. org/10.1186/s40494-016-0101-6

Germinario C, Izzo F, Mercurio M, Langella A, Sali D, Kakoulli I, De Bonis A, Grifa C (2018) Multi-analytical and non-invasive characterization of the polychromy of wall paintings at the Domus of Octavius Quartio in Pompeii. Eur Physical J Plus 133(9):359. https://doi.org/10.1140/epjp/i2018-12224-6

Gettens RJ, Feller RL, Chase WT (1972) Vermilion and cinnabar. Stud Conserv 17(2):45-69

Giumlia-Mair A, Morimoto Y IV, Ota K (2014) Mercury gilding in today's Japan: an amalgam of old and new. ISIJ Int 54(5):11061110. https://doi.org/10.2355/isijinternational.54.1106

Gleba M, Vanden Berghe I, Aldenderfer M (2016) Textile technology in Nepal in the $5^{\text {th }}-7^{\text {th }}$ centuries CE: the case of Samdzong. Sci Technol Archaeol Res 2(1):25-35. https://doi.org/10.1080/20548923.2015. 1110421

Gliozzo E, Burgio L (2021) Pigments - Arsenic-based yellows and reds. Archaeol Anthropol Sci. https://doi.org/10.1007/s12520-02101431-z

Gliozzo E, Ionescu C (2021) Pigments - Lead-based whites, reds, yellows and oranges and their alteration phases. Archaeol Anthropol Sci. https://doi.org/10.1007/s12520-021-01407-z

Gliozzo E, Cavari F, Damiani D, Memmi I (2012) Pigments and plasters from the roman settlement of Thamusida (Rabat, Morocco). Archaeometry 54(2):278-293. https://doi.org/10.1111/j.1475-4754. 2011.00617.x

Gliozzo E, Pizzo A, La Russa MF (2021) Mortars, plasters and pigments Research questions and sampling criteria. Archaeol Anthropol Sci. https://doi.org/10.1007/s12520-021-01393-2

Gomezjurado Garzón AJ (2008) El mopa-mopa o barniz de Pasto, comercialización indígena en el periodo colonial. Estudios Latinoamericanos 22-23:82-83

Gómez-Merino G, Majó T, Lorenzo C, Gispert-Guirado F, Stankova M, Francés J (2011) Identification of cinnabar by non-destructive techniques on a human mandible from Carrer Paris Chalcolithic hypogeum (Cerdanyola del Vallès, Barcelona, Spain). Revue d'Arch 35: 241-247. https://doi.org/10.4000/archeosciences.3298

Gómez-Morón MA, Ortiz P, Martín-Ramírez JM, Ortiz R, Castaing J (2016) A new insight into the vaults of the kings in the Alhambra (Granada, Spain) by combination of portable XRD and XRF. Microchem J 125:260-265. https://doi.org/10.1016/j.microc.2015. 11.023

González Cruz A (2011) La reina roja: una tumba real en Palenque. Turner Publicaciones S.L.
Goren Y, Goring-Morris AN, Segal I (2001) The technology of skull modelling in the Pre-Pottery Neolithic B (PPNB): regional variability, the relation of technology and iconography and their archaeological implications. J Archaeol Sci 28:671-690. https://doi.org/10. 1006/jasc. 1999.0573

Goring-Morris N, Horwitz LK (2007) Funerals and feasts during the PrePottery Neolithic B of the Near East. Antiquity 81(314):902-919. https://doi.org/10.1017/S0003598X00095995

Gorokhovich Y, Block KA, McNeil CL, Barrios E, Marionkova M (2020) Mercury source in Copan (Honduras): Local mining or trade? J Archaeol Sci Rep 33:102471. https://doi.org/10.1016/j. jasrep.2020.102471

Gray JE, Pribil MJ, Higueras PL (2013) Mercury isotope fractionation during ore retorting in the Almadén mining district, Spain. Chem Geol 357:150-157. https://doi.org/10.1016/j.chemgeo.2013.08.036

Grögler N, Geiss J, Grünenfelder M, Houtermans FG (1966) Isotopenuntersuchungen zur Bestimmung der Herkunft römischer Bleirohre und Bleibarren. Zeitschrift für Naturforschung A 21(7): 1167-1172. https://doi.org/10.1515/zna-1966-0744

Guerra M, Carvalho ML, Le Gac A, Manso M, Mortari C, Longelin S, Pessanha $S$ (2016) New insights into the red and green pigments in the illuminated foral charter of Setubal (1515) by combined use of $\mu$-Raman and X-ray fluorescence spectrometry. J Appl Phys 119(10):104902. https://doi.org/10.1063/1.4943617

Gulson B, Kamenov GD, Manton W, Rabinowitz M (2018) Concerns about quadrupole ICP-MS lead isotopic data and interpretations in the environment and health fields. Int $J$ Environ Res Public Health 15(4):723. https://doi.org/10.3390/ijerph15040723

Gutman M, Lesar-Kikelj M, Mladenovič A, Čobal-Sedmak V, Križnar A, Kramar S (2014) Raman microspectroscopic analysis of pigments of the Gothic wall painting from the Dominican Monastery in Ptuj (Slovenia). J Raman Spectrosc 45:1103-1109. https://doi.org/10. $1002 /$ jrs. 4628

Ha J-W, Lee S-J (2015) Identification of natural inorganic pigments used on $18^{\text {th }}$ century Korean traditional mural paintings by using a portable X-ray fluorescence. $J$ Ind Eng Chem 28:328-333. https://doi. org/10.1016/j.jiec.2015.03.011

Hao X, Wu H, Zhao Y, Tong T, Li X, Yang C, Tang Y, Shen X, Tong H (2017) Analysis on the composition/structure and lacquering techniques of the coffin of emperor qianlong excavated from the eastern imperial tombs. Sci Rep 7(1):8446. https://doi.org/10.1038/s41598017-08933-8

Hardy AD, Sutherland HH, Vaishnav R, Worthing MA (1995) A report on the composition of mercurials used in traditional medicines in Oman. J Ethnopharmacol 49(1):17-22. https://doi.org/10.1016/ 0378-8741(95)01296-6

Havighurst RJ (1926) Parameters in crystal structure. The mercurous halides. $J$ Am Chem Soc 48(8):2113-2125. https://doi.org/10.1021/ ja01419a016

Hayez V, Denoël S, Genadry Z, Gilbert B (2004) Identification of pigments on a $16^{\text {th }}$ century Persian manuscript by micro-Raman spectroscopy. J Raman Spectrosc 35(8-9):781-785. https://doi.org/10. $1002 /$ jrs. 1192

He L, Wang N, Zhao X, Zhou T, Xia Y, Liang J, Rong B (2012) Polychromic structures and pigments in Guangyuan ThousandBuddha Grotto of the Tang Dynasty (China). J Archaeol Sci 39(6):1809-1820. https://doi.org/10.1016/j.jas.2012.01.022

Hein A, Karatasios I, Mourelatos D (2009) Byzantine wall paintings from Mani (Greece): microanalytical investigation of pigments and plasters. Anal Bioanal Chem 395(7):2061-2071. https://doi.org/10. 1007/s00216-009-2967-6

Hendrie R (1847) Theophili, qui et Rugerus, presbyteri et monachi, libri III. De diversis artibus: seu, Diversarum artium schedula. London: Murray

Hendrix E (1998) Painted ladies of the Early Bronze Age. Metrop Museum Art Bull 55:4-15 
Hess C (2004) Brilliant achievements: the journey of Islamic glass and ceramics to Renaissance Italy. In: Hess C (Ed.) The arts of fire: Islamic influences on glass and ceramics of the Italian Renaissance. Getty Publications, pp. 1-34.

Higueras P, Saupé F, Tena JC (1999) Episodios de mineralización únicos en los yacimientos epigenéticos de mercurio de Almadén: evidencias isotópicas en el yacimiento de Las Cuevas. Geogaceta 25:107-109

Higueras P, Munhá J, Oyarzun R, Tassinari CCG, Ruiz IR (2005) First lead isotopic data for cinnabar in the Almadén district (Spain): Implications for the genesis of the mercury deposits. Mineral Deposita 40(1):115-122. https://doi.org/10.1007/s00126-0050471-2

Hintelmann H, Lu S (2003) High precision isotope ratio measurements of mercury isotopes in cinnabar ores using multi-collector inductively coupled plasma mass spectrometry. Analyst 128(6):635-639. https://doi.org/10.1039/b300451a

Hogan C, Da Pieve F (2015) Colour degradation of artworks: an ab initio approach to X-ray, electronic and optical spectroscopy analyses of vermilion photodarkening. J Anal At Spectrom 30:588-598. https:// doi.org/10.1039/c4ja00327f

Holakooei P, Karimy A-H, Saeidi-Anaraki F, Vaccaro C, Sabatini F, Degano I, Colombini MP (2020) Colourants on the wall paintings of a medi val fortress at the mount Sofeh in Isfahan, central Iran. $J$ Archaeol Sci Rep 29:102065. https://doi.org/10.1016/j.jasrep.2019. 102065

Holley EA, James McQuillan A, Craw D, Kim JP, Sander SG (2007) Mercury mobilization by oxidative dissolution of cinnabar $(\alpha-\mathrm{HgS})$ and metacinnabar ( $\beta-\mathrm{HgS})$. Chem Geol 240(3-4):313-325. https:// doi.org/10.1016/j.chemgeo.2007.03.001

Horvat M (2005) Determination of mercury and its compounds in water, sediment, soil and biological samples. In: Pirrone N, Mahaffey KR (eds) Dynamics of mercury pollution on regional and global scales: atmospheric processes and human exposures around the world. Springer, Boston, pp 153-190

Howe E, Kaplan E, Newman R, Frantz JH, Pearlstein E, Levinson J, Madden O (2018) The occurrence of a titanium dioxide/silica white pigment on wooden Andean qeros: a cultural and chronological marker. Heritage Sci 6:41. https://doi.org/10.1186/s40494-0180207-0

Hradil D, Hradilová J, Bezdička P, Švarcová S, Čermáková Z, Košařová $\mathrm{V}$, Němec I (2014) Crocoite $\mathrm{PbCrO}_{4}$ and mimetite $\mathrm{Pb}_{5}\left(\mathrm{AsO}_{4}\right)_{3} \mathrm{Cl}$ : rare minerals in highly degraded mediaeval murals in Northern Bohemia. J Raman Spectrosc 45(9):848-858. https://doi.org/10. 1002/jrs. 4556

Hu K, Bai C, Ma L, Bai K, Liu D, Fan B (2013) A study on the painting techniques and materials of the murals in the Five Northern Provinces' Assembly Hall, Ziyang, China. Heritage Sci 1(1):18. https://doi.org/10.1186/2050-7445-1-18

Huang C-F, Liu S-H, Lin-Shiau S-Y (2007) Neurotoxicological effects of cinnabar (a Chinese mineral medicine, $\mathrm{HgS}$ ) in mice. Toxicol Appl Pharmacol 224(2):192-201. https://doi.org/10.1016/j.taap.2007.07. 003

Hunt Ortiz MA, Hurtado Pérez V (2010) Pigmentos de sulfuros de mercurio-cinabrio- en contextos funerarios de época calcolítica en el Sur de la Península Ibérica: Investigaciones sobre el uso, depósitos minerales explotados y redes de distribución a través de la caracterización composicional e isotópica. In: Sainz ME, López Romero R, Cano MA, Díaz García JC (Eds.) Actas del VIII Congreso Ibérico de Arqueometría Teruel, pp. 123-132.

Hunt MA, Consuegra S, Díaz Del Río P, Hurtado V, Montero I (2011) Neolithic and Chalcolithic e VI to III millenia BC - use of cinnabar $(\mathrm{HgS})$ in the Iberian Peninsula: analytical identification and lead isotope data for an early mineral exploitation of the Almadén (Ciudad Real, Spain) mining district. In: Ortiz JE, Puche O,
Rábano I, Mazadiego LF (Eds.) History of Research on Mineral Resources. Cuadernos del Museo Geominero 13:3-13

Huq A, Stephens PW, Ayed N, Binous H, Burgio L, Clark RJH, Pantos E (2006) Combined technique analysis of the composition of Punic make-up materials. Appl Physics A: Mater Sci Proc 83(2):253-256. https://doi.org/10.1007/s00339-006-3518-z

Hurtado Pérez V (1999) Los inicios de la complejizacion social y el campaniforme en Extremadura. SPAL: Revista de prehistoria y arqueología de la Universidad de Sevilla 8:47-83

Hylleraas E (1926) Die anordnung der atome in den tetragonalen kristallen der einwertigen quecksilberhalogenide $\mathrm{Hg}_{2} \mathrm{Cl}_{2}, \mathrm{Hg}_{2} \mathrm{Br}_{2}$, $\mathrm{Hg}_{2} \mathrm{~J}_{2}$. Berechnung der optischen doppelbrechung von $\mathrm{Hg}_{2} \mathrm{Cl}_{2}$. $\mathrm{Z}$ Phys 36:859-896

Inácio N, Nocete Calvo F, Nieto Liñán JM, Sáez Ramos R, Rodríguez Bayona M, de la Corte Peram A (2013) A presença de cinábrio em contextos megalíticos do Sul de Portugal. In: Avila JJ, BustamanteÁlvarez M, García Cabezas M (eds) VI Encuentro de Arqueología del Suroeste Peninsular. (Villafranca de los Barros 2012). Ayuntamiento de Villafranca de los Barros, Villafranca de los Barros, pp 417-430

Ionescu O-H, Mohanu D, Stoica A-I, Baiulescu G-E (2004) Analytical contributions to the evaluation of painting authenticity from Princely church of Curtea de Arges. Talanta 63:815-823. https://doi.org/10. 1016/j.talanta.2003.12.042

Iordanidis A, Garcia-Guinea J, Strati A, Gkimourtzina A, Papoulidou A (2011) Byzantine wall paintings from Kastoria, northern Greece: Spectroscopic study of pigments and efflorescing salts. Spectrochimica Acta - Part A: Molecular and Biomolecular Spectroscopy 78(2):874-887. https://doi.org/10.1016/j.saa.2010. 12.055

Jain A, Sarsaiya S, Wu Q, Shi J, Lu Y (2019) New insights and rethinking of cinnabar for chemical and its pharmacological dynamics. Bioengineered 10(1):353-364. https://doi.org/10.1080/21655979. 2019.1652491

James EE (2005) Technical study of Ethiopian icons, National Museum of African Art, Smithsonian Institution. $J$ Am Inst Conserv 44(1): 39-50. https://doi.org/10.1179/019713605806082419

Jébrak M, Higueras PL, Marcoux E, Lorenzo S (2002) Geology and geochemistry of high-grade, volcanic rock-hosted, mercury mineralisation in the Nuevo Entredicho deposit, Almadén district, Spain. Mineral Deposita 37(5):421-432. https://doi.org/10.1007/ s00126-001-0222-y

Ježek M, Holub M, Zavřel J (2018) Metal-touching tools from ancient graves: the case of a Roman period royal burial. J Archaeol Sci Rep 18:333-342. https://doi.org/10.1016/j.jasrep.2018.01.037

Jovanovic B (1978) The origins of metallurgy in south-east and central Europe and problems of the earliest copper mining. In: Ryan M (ed) The origins of metallurgy in atlantic Europe: proceedings of the fifth Atlantic colloquium. (Dublin, 30 March-4 April 1978). stationery office, Dublin, pp 335-343

Juárez Martín JM (2010) El enterramiento en cueva artificial de La Molina (Lora de Estepa, Sevilla). Sevilla: Consejería de Cultura (Andalucía).

Juárez-Rodríguez O, Argote-Espino D, Santos-Ramírez M, López-García P (2018) Portable XRF analysis for the identification of raw materials of the Red Jaguar Sculpture in Chichén Itzá Mexico. Quat Int 483:148-159. https://doi.org/10.1016/j.quaint.2017.09.012

Kamiya Y, Honda T, Ohbuchi A, Miyakoshi T (2015) Simultaneous organic and inorganic analysis of colored oriental lacquerware by pyrolysis-gas chromatography/mass spectrometry. Int J Polymer Sci 2015:725467-725411. https://doi.org/10.1155/2015/725467

Kantoglu O, Ergun E, Kirmaz R, Kalayci Y, Zararsiz A, Bayir O (2018) Colour and ink characterization of ottoman diplomatic documents dating from the $13^{\text {th }}$ to the $20^{\text {th }}$ century. Restaurator 39(4):265-288. https://doi.org/10.1515/res-2018-0014 
Karapanagiotis I, Minopoulou E, Valianou L, Daniilia S, Chryssoulakis Y (2009) Investigation of the colourants used in icons of the Cretan School of iconography. Anal Chim Acta 647(2):231-242. https:// doi.org/10.1016/j.aca.2009.06.012

Karapanagiotis I, Lampakis D, Kostanta A, Farmakalidis H (2013) Identification of colourants in icons of the Cretan School of iconography using Raman spectroscopy and liquid chromatography. $J$ Archaeol Sci 40:1471-1478. https://doi.org/10.1016/j.jas.2012.11. 004

Karim-Cooper F (2006) Cosmetics in Shakespearean and Renaissance drama. Edinburgh University Press, Edinburgh, p 232

Karpova E, Nefedov A, Mamatyuk V, Polosmak N, Kundo L (2017) Multi-analytical approach (SEM-EDS, FTIR, Py-GC/MS) to characterize the lacquer objects from Xiongnu burial complex (NoinUla, Mongolia). Microchem J 130:336-344. https://doi.org/10. 1016/j.microc.2016.10.013

Kawano M, Takeuchi A, Takahashi K, Imazu S, Minami T (2014) Determination of sources of vermilion used in Japanese burial mound of Yayoi and Kofun periods. ISIJ Int 54(5):1155-1158. https://doi.org/10.2355/isijinternational.54.1155

Kegelman Neiman M, Balonis M, Kakoulli I (2015) Cinnabar alteration in archaeological wall paintings: an experimental and theoretical approach. Appl Physics A: Mater Sci Proc 121:915-938. https:// doi.org/10.1007/s00339-015-9456-x

Keune K, Boon JJ (2005) Analytical imaging atudies clarifying the process of the darkening of vermilion in paintings. Anal Chem 77(15): 4742-4750. https://doi.org/10.1021/ac048158f

Khramchenkova R, Biktagirova I, Gareev B, Kaplan P (2018) Horseheaded Saint Christopher fresco in the Sviyazhsk Assumption cathedral $\left(16^{\text {th }}-17^{\text {th }}\right.$ century, Russia): history and archaeometry. Mediter Archaeol Archaeom 18(3):195-207. https://doi.org/10. 5281/zenodo.1476971

Kidder AV, Jennings JD, Shook EM (1946) Excavations at Kaminaljuyu, Guatemala with technological notes by Anna O. Shepard. Publication 561. Carnegie Institution of Washington, Washington, p 284

Kitada M, Kohzuma Y, Koezuka T, Tateishi T (2015) Microstructure of red pigment layer painted on the Takamatsuzuka tumulus wall. Nippon Kinzoku Gakkaishi/J Jpn Instit Metals 79(2):64-70 (Japanese). https://doi.org/10.2320/jinstmet.J2014050

Knapp CW, Christidis GE, Venieri D, Gounaki I, Gibney-Vamvakari J, Stillings M, Photos-Jones E (2021) The ecology and bioactivity of some Greco-Roman medicinal minerals: the case of Melos earth pigments. Archaeol Anthropol Sci. https://doi.org/10.1007/s12520021-01396-Z

Kopp H (1843-1847) Geschichte der Chemie, 4th edn. Druck und Verlag von Friedrich Vieweg und Sohn, Braunschweig

Korenevskiy SN, Mednikova MB, Bochkovoy VV (2015) New findings relating to the Maikop-Novosvobodnaya burial rite. Archaeol Ethnol Anthropol Eurasia 43(2):34-42. https://doi.org/10.1016/j. aeae.2015.09.004

Kovala-Demertzi D, Papathanasis L, Mazzeo R, Demertzis MA, Varella EA, Prati S (2012) Pigment identification in a Greek icon by optical microscopy and infrared microspectroscopy. J Cult Herit 13(1): 107-113. https://doi.org/10.1016/j.culher.2011.06.003

Kramell AE, Wertmann P, Hosner D, Kluge R, Oehler F, Wunderlich CH, Tarasov PE, Wagner M, Csuk R (2016) A multi-analytical techniques based approach to study the colorful clothes and accessories from mummies of Eastern Central Asia. J Archaeol Sci Rep 10:464 473. https://doi.org/10.1016/j.jasrep.2016.11.021

Krauskopf KB (1951) Physical chemistry of quicksilver transportation in vein fluids. Econ Geol 46(5):498-523. https://doi.org/10.2113/ gsecongeo.46.5.498

Kriznar A., Höfler J., Ruíz-Conde A., Sánchez-Soto P. J. (2007) Caracterización arqueométrica de pigmentos y soportes procedentes de pinturas murales góticas (S. XIII-XV). Boletín de la Sociedad
Española de Cerámica y Vidrio 46(2):76-85. https://doi.org/10. 3989/cyv.2007.v46.i2.253

Kullerud G (1965) The mercury-sulfur system. Year book - Carnegie, 64. Institution of Washington, pp. 193-195.

Kumanotani J (1995) Urushi (oriental lacquer) - a natural aesthetic durable and future-promising coating. Prog Org Coat 26:163-195. https://doi.org/10.1016/0300-9440(95)00559-5

La Russa MF, Ruffolo SA (2021) Mortars and plasters - How to characterise mortars and plasters degradation. Archaeol Anthropol Sci. https://doi.org/10.1007/s12520-021-01405-1

Ladrón de Guevara S (1999) Imagen y pensamiento en el Tajín. Universidad Veracruzana/INAH, Xalapa

Lancaster LC (2021) Mortars and plasters - How mortars were made. The Literary Sources. Archaeol Anthropol Sci. https://doi.org/10.1007/ s12520-021-01395-0

Lavrič JV, Spangenberg JE (2003) Stable isotope (C, O, S) systematics of the mercury mineralization at Idrija, Slovenia: constraints on fluid source and alteration processes. Mineral Deposita 38(7):886-899. https://doi.org/10.1007/s00126-003-0377-9

Lazarich M, Briceño E, Ramos A, Carreras A, Fernández JV, Jenkins V, Feliu MJ, Versaci M, Torres F, Richarte MJ, Peralta P, Mesa M, Núñez M, Stratton S, Sánchez M, Grillé JM (2010a) La necrópolis colectiva en cuevas artificiales de Paraje De Monte Bajo (Alcalá de Los Gazules, Cádiz). In: Pérez Macías JA, Bomba ER (Eds.) IV Encuentro de Arqueología del Suroeste Peninsular. (Aracena 2008). Collectánea, 145, pp. 193-203.

Lazarich M, Briceño EM, Feliú MJ (2010b) El empleo de ocres en las sepulturas prehistóricas de la Baja Andalucía: la necrópolis de Paraje de Monte Bajo. In: Pérez Macías JA, Bomba ER (Eds.) IV Encuentro de Arqueología del Suroeste Peninsular. (Aracena 2008). Collectánea, 145, pp. 294-406.

Lazidou D, Lampakis D, Karapanagiotis I, Panayiotou C (2018) Investigation of the cross-section stratifications of icons using micro-Raman and micro-Fourier transform infrared (FT-IR) spectroscopy. Appl Spectrosc 72(8):1258-1271. https://doi.org/10.1177/ 0003702818777772

Lehmann WM (1924) XIX. Röntgenographische untersuchungen an natürlichem und synthetischem metacinnabarit $(\mathrm{HgS})$. Zeitschrift für Kristallographie - Crystalline Mater 60(1):379-413. https:// doi.org/10.1524/zkri.1924.60.1.379

Lei Z, Wu W, Shang G, Wu Y, Wang J (2017) Study on colored pattern pigments of a royal Taoist temple beside the Forbidden City (Beijing, China). Vib Spectrosc 92:234-244. https://doi.org/10. 1016/j.vibspec.2017.08.005

Levin L (2014) Mercury in the Environment. In: Granite EJ, Pennline HW, Senior C (Eds.) Mercury Control: For Coal-Derived Gas Streams. Wiley-VCH Verlag GmbH \& Co. KGaA, pp. 3-11.

Levstik MG, Mladenovič A, Križnar A, Kramar S (2019) A Raman microspectroscopy-based comparison of pigments applied in two gothic wall paintings in Slovenia. Periodico di Mineralogia 88(1): 95-104. https://doi.org/10.2451/2019PM778

Li T, Xie Y-F, Yang Y-M, Wang C-S, Fang X-Y, Shi J-L, He Q-J (2009) Pigment identification and decoration analysis of a $5^{\text {th }}$ century Chinese lacquer painting screen: a micro-Raman and FTIR study. J Raman Spectrosc 40(12):1911-1918. https://doi.org/10.1002/jrs. 2340

Li Z, Wang L, Chen H, Ma Q (2020a) Degradation of emerald green: scientific studies on multi-polychrome Vairocana Statue in Dazu Rock Carvings, Chongqing, China. Heritage Sci 8(1):64. https:// doi.org/10.1186/s40494-020-00410-2

Li P, Li W, Yu T, Qu F, Tam VWY (2020b) Investigation on early-age hydration, mechanical properties and microstructure of seawater sea sand cement mortar. Constr Build Mater 249:118776. https://doi. org/10.1016/j.conbuildmat.2020.118776

Li T, Liu C, Wang D (2020c) Applying micro-computed tomography (micro-CT) and Raman spectroscopy for non-invasive 
characterization of coating and coating pigments on ancient Chinese papers. Heritage Sci 8(1):22. https://doi.org/10.1186/s40494-02000366-3

Li GH, Chen Y, Sun XJ, Duan PQ, Lei Y, Zhang LF (2020d) An automatic hyperspectral scanning system for the technical investigations of Chinese scroll paintings. Microchem J 155:104699. https://doi. org/10.1016/j.microc.2020.104699

Liesau C, Blasco C, Ríos P, Vega J, Menduiña R, Blanco JF, Baena J, Herrera T, Petri A, Gómez JL (2008) Un espacio compartido por vivos y muertos: el poblado calcolítico de fosos de Camino de las Yeseras (San Fernando de Henares, Madrid). Complutum 19(1):97120

Linné S (1942) Mexican highland cultures. Archaeological researches at Teotihuacan, Calpulalpan and Chalchicomula in 1934/35. New Series, 7. The Ethnographical Museum of Sweden, Stockholm, p 224

Liu L (2004) The Chinese Neolithic: trajectories to early states. Cambridge University Press, Cambridge

Liu J, Shi J-Z, Yu L-M, Goyer RA, Waalkes MP (2008) Mercury in traditional medicines: is cinnabar toxicologically similar to common mercurials? Exp Biol Med 233(7):810-817. https://doi.org/10.3181/ 0712-MR-336

Liu L, Shen W, Zhang B, Ma Q (2016) Microchemical study of pigments and binders in polychrome relics from maiji mountain grottoes in northwestern China. Microsc Microanal 22(4):845-856. https://doi. org/10.1017/S1431927616011302

Liu J, Wei L-X, Wang Q, Lu Y-F, Zhang F, Shi J-Z, Li C, Cherian MG (2018a) A review of cinnabar (HgS) and/or realgar (As4S4)-containing traditional medicines. $J$ Ethnopharmacol 210:340-350. https:// doi.org/10.1016/j.jep.2017.08.037

Liu L-Y, Zhang B-J, Yang H, Zhang Q (2018b) The analysis of the colored paintings from the Yanxi Hall in the Forbidden City. Guang Pu Xue Yu Guang Pu Fen Xi/Spectroscopy Spectral Anal 38(7):2054-2063 (Chinese). https://doi.org/10.3964/j.issn.10000593(2018)07-2054-10

Liu XY, Lv MQ, Liu M, Wu ZH, Lv JF (2019) Characterization and identification of lacquer films from the Qin and Han Dynasties. BioResources 14(4):9509-9517. https://doi.org/10.15376/biores. 14.4.9509-9517

López Cruz O, García Bueno A, Medina Flórez VJ (2011) Evolución del color en el alero de la fachada del rey D. Pedro I, Real Alcázar de Sevilla. Aportaciones del estudio de materiales a la identificación de las intervenciones de restauración a lo largo de su historia. Arqueol de la Arquitectura 8:163-178. https://doi.org/10.3989/arqarqt.2011. 10016

López Puértolas C, Manzanilla Naim LR, Vázquez de Ágredos Pascual, M.L. (2019) Characterization of color production in Xalla's palace complex, Teotihuacan. STAR: Science \& Technology of Archaeological Research 5(2):221-233. https://doi.org/10.1080/ 20548923.2020.1723240

Lu R, Kamiya Y, Miyakoshi T (2007) Preparation and characterization of Melanorrhoea usitata lacquer film based on pyrolysis-gas chromatography/mass spectrometry. J Anal Appl Pyrolysis 78: 172-179. https://doi.org/10.1016/j.jaap.2006.06.006

Lukačević I, Ergotić I, Vinaj M (2013) Non-destructive analyses of $16^{\text {th }}$ century printed book "Osorio" with the colorful fore-edge miniatures. Croat Chem Acta 86(2):207-214. https://doi.org/10.5562/ cca2040

Luo W, Si Y, Wang H, Qin Y, Huang F, Wang C (2011) Leather material found on a 6th B.C. Chinese bronze sword: a technical study. Spectrochimica Acta - Part A: Molecular and Biomolecular Spectroscopy 79(5):1630-1633. https://doi.org/10.1016/j.saa.2011. 05.023

Ma X-M, Lu R, Miyakoshi T (2014) Application of pyrolysis gas chromatography/mass spectrometry in lacquer research: a review. Polymers 6:132-144. https://doi.org/10.3390/polym6010132
Ma X, Shi Y, Khanjian H, Schilling M, Li M, Fang H, Cui D, Kakoulli I (2017) Characterization of Early Imperial lacquerware from the Luozhuang Han Tomb, China. Archaeometry 59(1):121-132. https://doi.org/10.1111/arcm.12226

Magaloni, D. (1998) El arte en el hacer: técnica pictórica y color en las pinturas de Bonampak. In: De la Fuente B (Ed.) La pintura mural prehispánica en México II, Área Maya Bonampak, II. EstudiosMexico: IIE-UNAM, pp. 49-80.

Magaloni D, Newman R, Baños L, Falcon T (1993) Los pintores de Bonampak. In: Robertson MG (Ed.) Eight Palenque Round Table, $\mathrm{X}$ edn. pre-Columbian Art Research Institute, San Francisco, pp $159-168$

Malletzidou L, Zorba TT, Patsiaoura D, Lampakis D, Beinas P, Touli V, Chrissafis K, Karapanagiotis I, Pavlidou E, Paraskevopoulos KM (2019) Unraveling the materials and techniques of post-Byzantine wall paintings: Is there a sole pictorial phase at the catholicon of Stomion, Central Greece? Spectrochimica Acta - Part A: Molecular and Biomolecular Spectroscopy 206:328-339. https://doi.org/10. 1016/j.saa.2018.07.105

Manceau A, Lemouchi C, Enescu M, Gaillot A-C, Lanson M, Magnin V, Glatzel P, Poulin BA, Ryan JN, Aiken GR, Gautier-Luneau I, Nagy $\mathrm{KL}$ (2015) Formation of mercury sulfide from $\mathrm{Hg}$ (II)-thiolate complexes in natural organic matter. Environ Sci Technol 49(16):97879796. https://doi.org/10.1021/acs.est.5b02522

Manso M, Gac AL, Longelin S, Pessanha S, Frade JC, Guerra M, Candeias AJ, Carvalho ML (2013) Spectroscopic characterization of a masterpiece: the Manueline foral charter of Sintra. Spectrochimica Acta - Part A: Molecular and Biomolecular Spectroscopy 105:288-296. https://doi.org/10.1016/j.saa.2012.11. 110

Manzanilla L (2005) The emergence of complex urban societies in Central Mexico: the case of Teotihuacan. Archaeol Latin Am:90126. https://doi.org/10.4324/9780203984819-15

Maras A, Botticelli M, Ballirano P (2013) Archaeometric investigations on cinnabar provenance and origin by X-ray powder diffraction: preliminary data. Int J Conserv Sci 4(SPL.ISS):685-692

Martínez-Fernández MJ, Gavilán B, Barrios J, Montealegre L (1999) Materias primas colorantes en Murciélagos de Zuheros (Córdoba): caracterización y procedencia. In: Bernabeu J, Orozco T (Eds.) II Congreso de Neolítico de la Península Ibérica, 2nd edn. PLAV, Saguntum, pp. 111-116

Martín-Gil J, Martín-Gil FJ, Delibes-de-Castro G, Zapatero-Magdaleno P, Sarabia-Herrero FJ (1995) The first known use of vermillion. Experientia 51(8):759-761. https://doi.org/10.1007/BF01922425

Martín-Izard A, Gumiel P, Arias M, Cepedal A, Fuertes-Fuente M, Reguilón R (2009) Genesis and evolution of the structurally controlled vein mineralization (Sb-Hg) in the Escarlati deposit (León, Spain): evidence from fault population analysis methods, fluidinclusion research and stable isotope data. $J$ Geochem Explor 100(1):51-66. https://doi.org/10.1016/j.gexplo.2008.04.002

Mason RB (2004) Shine like the sun. Luster-painted and associated pottery from the Medieval Middle East. Bibliotheca Iranica: Islamic Art and Architecture, 12. Mazda Publishers Inc, Canada, p 266

Mastrotheodoros GP, Beltsios KG, Bassiakos Y (2021) Pigments - Ironbased red, yellow and brown ochres. Archaeol Anthropol Sci (forthcoming)

Maudslay AP (1889-1902) Biologia Centrali-Americana or Contributions to the knowledge of the fauna and flora of Mexico and Central America. Porter, Dulau \& Co., London

Mazzocchin GA, Agnoli F, Mazzocchin S, Colpo I (2003) Analysis of pigments from Roman wall paintings found in Vicenza. Talanta 61: 565-572. https://doi.org/10.1016/S0039-9140(03)00323-0

Mazzocchin GA, Agnoli F, Salvadori M (2004) Analysis of Roman age wall paintings found in Pordenone, Trieste and Montegrotto. Talanta 64(3):732-741. https://doi.org/10.1016/j.talanta.2004.03. 055 
Mazzocchin GA, Baraldi P, Barbante C (2008) Isotopic analysis of lead present in the cinnabar of Roman wall paintings from the Xth Regio "(Venetia et Histria)" by ICP-MS. Talanta 74(4):690-693. https:// doi.org/10.1016/j.talanta.2007.06.048

Mazzocchin GA, Vianello A, Minghelli S, Rudello D (2010) Analysis of roman wall paintings from the thermae of 'Iulia Concordia'. Archaeometry 52(4):644-655. https://doi.org/10.1111/j.1475-4754. 2009.00501.x

McCormack JK (2000) The darkening of cinnabar in sunlight. Mineral Deposita 35(8):796-798. https://doi.org/10.1007/s001260050281

Mel'chakova LV, Kiseleva IA (1990) Specific heat, temperature, and enthalpy of the cinnabar- metacinnabarite transition. Geochem Int 27(6):138-142

Melchar D, Burgio L, Fernandez V, Keneghan B, Newman R (2021) A collaborative, multidisciplinary and multi-analytical approach to the characterisation of barniz de Pasto objects from the V\&A collections. In: Bridgland J (Ed.) Transcending Boundaries: Integrated Approaches to Conservation. ICOM-CC $19^{\text {th }}$ Triennial Conference Preprints (Beijing, 17-21 May 2021). Paris: International Council of Museums.

Mellaart J (1967) Catal Hüyük - a Neolithic town in Anatolia. McGrawHill, New York

Melo MJ, Miguel C (2010) The making of vermilion in medieval Europe: historically accurate reconstructions from The book on how to make colours. In: Kroustallis, S., Del Egido, M. (Eds.) Fatto D'Archimia. History and identification of artificial pigments. Madrid: Ministerio de Educacion, Cultura y Deporte, pp. 181-195.

Miguel C, Pinto JV, Clarke M, Melo MJ (2014) The alchemy of red mercury sulphide: the production of vermilion for medieval art. Dyes Pigments 102:210-217. https://doi.org/10.1016/j.dyepig. 2013.10.041

Mikolaichuk AG, Dutchak VI (1965) A new modification of sulfurous mercury. Mineralogicheskiy Sbornik L'vovskogo Universiteta 19(3): 368-372 (Russian).

Milanesi G (1864) Dell 'Arte del vetro per musaico tre trattatelli dei secoli XIV e XV, ora per la prima volta pubblicati. Gaetano Romagnoli, Bologna, p 218

Minami T, Imai A, Bunno M, Kawakami K, Imazu S (2005) Short contribution: using sulfur isotopes to determine the sources of vermillion in ancient burial mounds in Japan. Geoarchaeology 20(1):7984. https://doi.org/10.1002/gea.20035

Minami T, Imazu S, Kitagawa M, Makita M, Nishikawa K, Nagamatsu S, Tanaka T, Urabe T, Kidera M, Ishizuka K, Takaku Y, Takahashi K (2013) Sources of vermilion collected from ancient Japanese tombs determined by the measurements of lead isotopes. Bunseki Kagaku 62(9):825-833. https://doi.org/10.2116/bunsekikagaku.62.825

Minami T, Hatanaka K, Motizuki Y, Nakai Y, Takahashi K (2019) A method of collecting trace amounts of vermilion from artifacts for source estimation by sulfur isotope $\left(\delta^{34} \mathrm{~S}\right)$ analysis: use of sulfur-free adhesive tape to minimize damage to the artifact body during sampling. J Archaeol Sci Rep 28:102027. https://doi.org/10.1016/j. jasrep.2019.102027

Minami T, Takeuchi A, Imazu S, Okuyama M, Higashikage Y, Mizuno T, Okabayashi K, Takahashi K (2021) Identification of source mine using sulfur, mercury, and lead isotope analyses of vermilion used in three representative tombs from Kofun period in Japan. J Archaeol Sci Rep 37:102970. https://doi.org/10.1016/j.jasrep.2021.102970

Mioč UB, Colomban P, Sagon G, Stojanović M, Rosić A (2004) Ochre decor and cinnabar residues in Neolithic pottery from Vinča, Serbia. J Raman Spectrosc 35(10):843-846. https://doi.org/10.1002/jrs. 1221

Miśta-Jakubowska E, Czech Błońska R, Duczko W, Gójska AM, Kalbarczyk P, Żabiński G, Trela K (2019) Archaeometric studies on early medieval silver jewellery from Central and Eastern Europe. Archaeol Anthropol Sci 11:6705-6723. https://doi.org/10.1007/ s12520-019-00935-Z
Molera J, Mesquida M, Pérez-Arantegui J, Pradell T, Vendrell-Saz M (2001) Lustre recipes from a Medieval workshop in Paterna. Archaeometry 43(4):455-460. https://doi.org/10.1111/1475-4754. 00028

Molera J, Bayés C, Roura P, Crespo D, Pradell T (2007) Key parameters in the production of medieval luster colors and shines. J Am Ceram Soc 90(7):2245-2254. https://doi.org/10.1111/j.1551-2916.2007. 01563.x

Molleson T, Comerford G, Moore A (1992) A Neolithic painted skull from Tell Abu Hureyra, Northern Syria. Camb Archaeol J 2(2):231236. https://doi.org/10.1017/S0959774300000603

Mora-Osejo LE (1977) El barniz de Pasto. Caldasia:5-31

Mounier A, Denoël C, Daniel F (2016) Material identification of three French medieval illuminations of the $\mathrm{XVI}^{\text {th }}$ century by hyperspectral imaging (Treasury of Bordeaux Cathedral, France). Color Res Appl 41(3):302-307. https://doi.org/10.1002/col.22042

Mounier A, Schlicht M, Mulliez M, Pacanowski R, Lucat A, Mora P (2020) In search of the lost polychromy of English medieval alabaster panels in the Southwest of France. Color Res Appl 45(3):427449. https://doi.org/10.1002/col.22482

Murat Z (2021) Wall paintings through the ages. The medieval period (Italy, $12^{\text {th }}-15^{\text {th }}$ century). Archaeol Anthropol Sci. https://doi.org/10. 1007/s12520-021-01410-4

Murthy SRN (1983) Minerals used in Indian medicine. J Geol Soc India 24(12):664-667

Naziree S (2013) From Craft to Art - Vietnamese Lacquer Paintings. Thavibu Gallery Co., Bangkok, p 55

Needham J, Ping-Yu H, Gwei-djen L (1976) Science and civilisation in China. Volume 5, chemistry and chemical technology. Part 3: spagyrical discovery and invention: historical survey, from cinnabar elixirs to synthetic insulin. Cambridge University Press, Cambridge

Newman R, Derrick M (2001) Painted qero cups from the Inka and Colonial periods in Peru: an analytical study of pigments and media. MRS Online Proc Library 712:98. https://doi.org/10.1557/PROC712-II9.8

Newman R, Kaplan E, Derrick M (2015) Mopa mopa: Scientific analysis and history of an unusual South American resin used by the Inka and Artisans in pasto, Colombia. J Am Inst Conserv 54(3):123-148. https://doi.org/10.1179/1945233015Y.0000000005

Niederschlag E, Pernicka E, Seifert T, Bartelheim M (2003) The determination of lead isotope ratios by Multiple Collector ICP-MS: a case study of Early Bronze Age artefacts and their possible relation with ore deposits of the Erzgebirge. Archaeometry 45(1):61-100. https:// doi.org/10.1111/1475-4754.00097

Niimura N, Miyakoshi T (2006) Structural study of oriental lacquer films during the hardening process. Talanta 70:146-152. https://doi.org/ 10.1016/j.talanta.2005.12.039

Niimura N, Miyakoshi T, Onodera J, Higuchi T (1996a) Characterization of Rhus vernicifera and Rhus succedanea lacquer films and their pyrolysis mechanisms studied using two-stage pyrolysis-gas chromatography/mass spectrometry. J Anal Appl Pyrolysis 37(2): 199-209. https://doi.org/10.1016/0165-2370(96)00945-X

Niimura N, Miyakoshi T, Onodera J, Higuchi T (1996b) Structural studies of Melanorrhoea usitate lacquer film using two-stage pyrolysis/ gas chromatography/mass spectrometry. Rapid Commun Mass Spectrom 10(14):1719-1724.

Niimura N, Miyakoshi T, Onodera J, Higuchi T (1999) Identification of ancient lacquer film using two-stage pyrolysis-gas chromatography/ mass spectrometry. Archaeometry 41(1):137-149. https://doi.org/ 10.1111/j.1475-4754.1999.tb00856.x

Nöller R (2013) Cinnabar reviewed: characterization of the red pigment and its reactions. Stud Conserv 60(2):79-87. https://doi.org/10. 1179/2047058413Y.0000000089

Nørgaard HW, Pernicka E, Vandkilde H (2019) On the trail of Scandinavia's early metallurgy: provenance, transfer and mixing. 
PLoS One 14(7):e0219574. https://doi.org/10.1371/journal.pone. 0219574

Obermaier H (1919) El Dolmen deMatarrubilla (Sevilla). Comisión de Investigaciones Paleontológicas y Prehistóricas. Memoria, 26. Madrid: Museo Nacional de Ciencias Naturales

Ohmiya T (1974) Thermal expansion and the phase transformation in mercury sulphide. J Appl Crystallogr 7(3):396-397. https://doi. org/10.1107/S0021889874009885

Olhausen Sv (1925) Strukturuntersuchungen nach der Debye-Scherrermethode. Zeitschrift für Kristallographie - Crystalline Mater 61(1): 463-514. https://doi.org/10.1524/zkri.1924.61.1.463

Oliveira J (1997) Monumentos megalíticos da bacia hidrográfica do rio Sever. Ibn Maruán, Lisboa

Oubelkacem Y, Lamhasni T, El Bakkali A, Lyazidi SA, Haddad M, BenNcer A (2021) Parchments and coloring materials in two IXth century manuscripts: On-site non-invasive multi-techniques investigation. Spectrochimica Acta - Part A: Molecular and Biomolecular Spectroscopy 247:119093. https://doi.org/10.1016/j.saa.2020. 119093

Padeletti G, Fermo P (2003a) How the masters in Umbria, Italy, generated and used nanoparticles in art fabrication during the Renaissance period. Appl Physics A: Mater Sci Proc 76:515-525. https://doi. org/10.1007/s00339-002-1935-1

Padeletti G, Fermo P (2003b) Italian Renaissance and Hispano-Moresque lustre-decorated majolicas: imitation cases of Hispano-Moresque style in central Italy. Appl Physics A: Mater Sci Proc 77:125-133. https://doi.org/10.1007/s00339-002-2048-6

Padeletti G, Fermo P (2004) Production of gold and ruby-red lustres in Gubbio (Umbria, Italy) during the Renaissance period. Appl Physics A: Mater Sci Proc 79:241-245. https://doi.org/10.1007/s00339004-2513-5

Padilla JAL, Ibáñez MPM, de la Rosa MA, Martín LG, García CR, Mascarós SM (2012) Ocher and cinnabar in the argaric funerary record [Ocre y cinabrio en el registro funerario de el argar]. Trab Prehist 69(2):273-292. https://doi.org/10.3989/tp.2012.12092

Padovani S, Sada C, Mazzoldi P, Brunetti B, Borgia I, Sgamellotti A, Giulivi A, D'Acapito F, Battaglin G (2003) Copper in glazes of Renaissance luster pottery: nanoparticles, ions, and local environment. J Appl Phys 93(12):10058-10063. https://doi.org/10.1063/1. 1571965

Padovani S, Borgia I, Brunetti B, Sgamellotti A, Giulivi A, D'Acapito F, Mazzoldi P, Sada C, Battaglin G (2004) Silver and copper nanoclusters in the lustre decoration of Italian Renaissance pottery: an EXAFS study. Appl Physics A: Mater Sci Proc 79:229-233. https://doi.org/10.1007/s00339-004-2516-2

Padovani S, Puzzovio D, Sada C, Mazzoldi P, Borgia I, Sgamellotti A, Brunetti B, Cartechini L, D'Acapito F, Maurizio C, Shokoui F, Oliaiy P, Rahighi J, Lamehi-Rachti M, Pantos E (2006) XAFS study of copper and silver nanoparticles in glazes of medieval middle-east lustreware $\left(10^{\text {th }}-13^{\text {th }}\right.$ century). Appl Physics A: Mater Sci Proc 83: 521-528. https://doi.org/10.1007/s00339-006-3558-4

Pavlidou E, Civici N, Caushi E, Anastasiou L, Zorba T, Hatzikraniotis E, Paraskevopoulos KM (2008) Study of painting materials and techniques in the $18^{\text {th }}$ century St. Athanasius Church in Moschopolis, Albania. Mater Res Soc Symp Proc 1047:61-69

Peabody C (1927) Red paint. J de la Société des Américanistes 19:207244

Pearlstein EJ, Kaplan E, Howe E, Levinson J (2000) Technical analyses of painted Inka and colonial qeros. In: Objects Specialty Group Postprints, Volume Six, 1999. The American Institute for Conservation of Historic \& Artistic Works, Washington, pp 94-111

Pendergast DM (1982) Ancient Maya mercury. Science 217(4559):533535. https://doi.org/10.1126/science.217.4559.533

Pereira J (1849-1850) The elements of materia medica and therapeutics, 3rd edn. Longman, London
Pereira-Pardo L, Tamburini D, Dyer J (2019) Shedding light on the colours of medieval alabaster sculptures: Scientific analysis and digital reconstruction of their original polychromy. Color Res Appl 44(2): 221-233. https://doi.org/10.1002/col.22323

Pérez-Alonso M, Castro K, Álvarez M, Madariaga JM (2004) Scientific analysis versus restorer's expertise for diagnosis prior to a restoration process: the case of Santa Maria Church (Hermo, Asturias, North of Spain). Anal Chim Acta 524(1-2):379-389. https://doi.org/10.1016/ j.aca.2004.06.034

Pérez-Arantegui J (2021) Not only wall paintings - Pigments for cosmetics. Archaeol Anthropol Sci. https://doi.org/10.1007/s12520021-01399-w

Pérez-Arantegui J, Pardos C (2008) Lustre recipes for Hispano-Moresque ceramic decoration in Muel (Aragón, Spain), or 'How Much a Little Copper Weighs'. In: Martinon-Torres M, Rehren Th. (Eds.) Archaeology, History and Science. Routledge, pp. 151-166.

Pérez-Arantegui J, Molera J, Larrea A, Pradell T, Vendrell-Saz M, Borgia I, Brunetti BG, Cariati F, Fermo P, Mellini M, Sgamellotti A, Viti C (2001) Luster pottery from the thirteenth century to the sixteenth century: a nanostructured thin metallic film. $J$ Am Ceram Soc 84: 442-446. https://doi.org/10.1111/j.1151-2916.2001.tb00674.x

Pérez-Arantegui J, Larrea A, Molera J, Pradell T, Vendrell-Saz M (2004) Some aspects of the characterization of decorations on ceramic glazes. Appl Physics A: Mater Sci Proc 79:235-239. https://doi. org/10.1007/s00339-004-2508-2

Pérez-Rodríguez JL, Robador MD, Centeno MA, Siguenza B, Durán A (2014) Wall paintings studied using Raman spectroscopy: a comparative study between various assays of cross sections and external layers. Spectrochimica Acta - Part A: Molecular and Biomolecular Spectroscopy 120:602-609. https://doi.org/10.1016/j.saa.2013.10. 052

Pérez-Rodríguez JL, Franquelo ML, Durán A (2020) TG, DTA and X-ray thermodiffraction study of wall paintings from the fifteenth century. $J$ Therm Anal Calorim 143:3257-3265. https://doi.org/10.1007/ s10973-020-09420-5

Pernicka E, Begemann F, Schmitt-Strecker S, Grimanis AP (1990) On the composition and provenance of metal objects from Poliochni on Lemnos. Oxf J Archaeol 9(3):263-298. https://doi.org/10.1111/j. 1468-0092.1990.tb00370.x

Pernicka E, Begemann F, Schmitt-Strecker S, Wagner GA (1993) Eneolithic and Early Bronze Age copper artefacts from the Balkans and their relation to Serbian copper ores. Praehstorische Zeitschrift 68:1-57. https://doi.org/10.1515/prhz.1993.68.1.1

Petrova O, Pankin D, Povolotckaia A, Borisov E, Krivul'ko T, Kurganov N, Kurochkin A (2019) Pigment palette study of the XIX century plafond painting by Raman spectroscopy. J Cult Herit 37:233-237. https://doi.org/10.1016/j.culher.2018.11.010

Pinna D, Conti C, Mazurek J (2020) Polychrome sculptures of medieval Italian monuments: Study of the binding media and pigments. Microchem J 158:105100. https://doi.org/10.1016/j.microc.2020. 105100

Piovesan R, Mazzoli C, Maritan L, Cornale P (2012) Fresco and limepaint: an experimental study and objective criteria for distinguishing between these painting techniques. Archaeometry 54(4):723-736. https://doi.org/10.1111/j.1475-4754.2011.00647.x

Piovesan R, Maritan L, Neguer J (2014) Characterising the unique polychrome sinopia under the Lod Mosaic, Israel: pigments and painting technique. J Archaeol Sci 46(1):68-74. https://doi.org/10.1016/j.jas. 2014.02.032

Piovesan R, Maritan L, Amatucci M, Nodari L, Neguer J (2016) Wall painting pigments of Roman Empire age from Syria Palestina province (Israel). Eur J Mineral 28(2):435-448. https://doi.org/10.1127/ ejm/2015/0027-2500

Pool C (2007) Olmec archaeology and early Mesoamerica. Cambridge University Press, Cambridge 
Porat N, Ilani S (1998) A Roman period palette: composition of pigments from King Herod's palaces in Jericho and Massada, Israel. Isr $J$ Earth Sci 47(2): 75-85

Portell JD (1992) Colored glazes on silver-gilded surfaces. Stud Conserv 37(S1):116-118. https://doi.org/10.1179/sic.1992.37.s1.024

Potter RW, Barnes HL (1978) Phase relations in the binary Hg-S. Am Mineral 63:1143-1152

Pozzi F, Basso E, Katz M (2020) In search of Humboldt's colors: materials and techniques of a $17^{\text {th }}$-century lacquered gourd from Colombia. Heritage Sci 8:101. https://doi.org/10.1186/s40494020-00449-1

Pradell T, Molera J, Vendrell M, Pérez-Arantegui J, Pantos E, Roberts M, DiMichiel M (2004) Role of cinnabar in luster production. $J$ Am Ceram Soc 87(6):1018-1023. https://doi.org/10.1111/j.1551-2916. 2004.01018.x

Pradell T, Molera J, Roque J, Vendrell-Saz M, Smith AD, Pantos E, Crespo D (2005) Ionic-exchange mechanism in the formation of Medieval luster decorations. J Am Ceram Soc 88(5):1281-1289. https://doi.org/10.1111/j.1551-2916.2005.00223.x

Pradell T, Molera J, Smith AD, Tite MS (2008a) Early Islamic lustre from Egypt, Syria and Iran $\left(10^{\text {th }}\right.$ to $13^{\text {th }}$ century AD). J Archaeol Sci 35 : 2649-2662. https://doi.org/10.1016/j.jas.2008.05.011

Pradell T, Molera J, Pantos E, Smith AD, Martin CM, Labrador A (2008b) Temperature resolved reproduction of medieval luster. Appl Physics A: Mater Sci Proc 90(1):81-88. https://doi.org/10. 1007/s00339-007-4226-z

Pribil MJ, Rimondi V, Costagliola P, Lattanzi P, Rutherford DL (2020) Assessing mercury distribution using isotopic fractionation of mercury processes and sources adjacent and downstream of a legacy mine district in Tuscany, Italy. Appl Geochem 117:104600. https:// doi.org/10.1016/j.apgeochem.2020.104600

Prieto G, Wright V, Burger RL, Cooke CA, Zeballos-Velasquez EL, Watanave A, Suchomel MR, Suescun L (2016) The source, processing and use of red pigment based on hematite and cinnabar at Gramalote, an early Initial Period (1500-1200 cal. B.C.) maritime community, north coast of Peru. J Archaeol Sci Rep 5:45-60. https:// doi.org/10.1016/j.jasrep.2015.10.026

Protobyakonova ZM, Timofeeva TS, Fedorchuk OP (1971) HgS modification in the Central Asia Hg-Sb deposits. Zapiski Vserossijskogo Mineralogicheskogo Obshchestva 100:731-738 (Russian)

Quarta G, Giorgia A, Ingravallo E, Tiberi I, Calcagnile L (2018) Radiocarbon dates and XRF analyses from two prehistoric contexts in the Badisco area (Otranto-Le). Measurement: J Int Measur Confederation 125:279-283. https://doi.org/10.1016/j. measurement.2018.04.093

Quattrini MV, Ioele M, Sodo A, Priori GF, Radeglia D (2014) A seventeenth century Japanese painting: scientific identification of materials and techniques. Stud Conserv 59(5):328-340. https://doi.org/ 10.1179/2047058413Y.0000000086

Quintana P, Tiesler V, Conde M, Trejo-tzab R, Bolio C, Alvarado-gil JJ, Aguilar D (2015) Spectrochemical characterization of red pigments used in Classic Period Maya funerary practices. Archaeometry 57(6):1045-1059. https://doi.org/10.1111/arcm.12144

Rackham H (1952) Pliny, natural history, volume IX: Books 33-35. Loeb Classical Library, 394. Cambridge, MA: Harvard University Press

Radepont M, de Nolf W, Janssens K, Van der Snickt G, Coquinot Y, Klaassen L, Cotte M (2011) The use of microscopic X-ray diffraction for the study of $\mathrm{HgS}$ and its degradation products corderoite $(\alpha$ $\left.\mathrm{Hg}_{3} \mathrm{~S}_{2} \mathrm{Cl}_{2}\right)$, kenhsuite $\left(\gamma-\mathrm{Hg}_{3} \mathrm{~S}_{2} \mathrm{Cl}_{2}\right)$ and calomel $\left(\mathrm{Hg}_{2} \mathrm{Cl}_{2}\right)$ in historical paintings. J Anal At Spectrom 26:959-968. https://doi.org/10. 1039/C0JA00260G

Radepont M, Coquinot Y, Janssens K, Ezrati J-J, de Nolf W, Cotte M (2015) Thermodynamic and experimental study of the degradation of the red pigment mercury sulfide. J Anal At Spectrom 30:599-612. https://doi.org/10.1039/c4ja00372a
Rafalska-Lasocha A, Lasocha W, Grzesiak M, Dziembaj R (2010) X-ray powder diffraction investigations of Ruthenian-Byzantine frescoes from the royal Wawel Cathedral (Poland). Powder Diffract 25(3): 258-263. https://doi.org/10.1154/1.3478748

Ramos J, Domínguez-Bella S, Castañeda V, Lazarich M, Pérez M, Morata M, Martínez C, Cáceres I, Feliu MJ (1997) El dolmen de Alberite (Villamartín). Excavación, analítica y su aportación al conocimiento de las sociedades del V milenio a.n.e. en el NE de Cádiz. In: Rodríguez Casal AA (Ed.) $O$ neolítico atlántico $e$ as orixes do megalitismo. Actas do Coloquio Internacional (Santiago de Compostela, 1-6 April 1996). Santiago de Compostela: Universidade de Santiago de Compostela, pp. 839-854.

Ramsdell LS (1925) The crystal structures of some metallic sulfides. Am Mineral 10:281-304

Rasmussen KL, Skytte L, Jensen AJ, Boldsen JL (2015) Comparison of mercury and lead levels in the bones of rural and urban populations in Southern Denmark and Northern Germany during the Middle Ages. J Archaeol Sci Rep 3:358-370. https://doi.org/10.1016/j. jasrep.2015.06.021

Rigon C, Izzo FC, Vázquez De Ágredos Pascual ML, Campíns-Falcó P, Van Keulen H (2020) New results in ancient Maya rituals researches: the study of human painted bones fragments from Calakmul archaeological site (Mexico). J Archaeol Sci Rep 32: 102418. https://doi.org/10.1016/j.jasrep.2020.102418

Roberts AC, Szymanski JT, Erd RC, Criddle AJ, Bonardi M (1993) Deanesmithite, $\mathrm{Hg}_{2}{ }^{1+} \mathrm{Hg}_{3}{ }^{2+} \mathrm{Cr}^{+} \mathrm{O}_{5} \mathrm{~S}_{2}$, a new mineral species from the Clear Creek claim, San Benito County, California. Can Mineral 31(4):787-793

Roberts AC, Grice JD, Gault RA, Criddle AJ, Erd RC (1996) Hanawaltite, $\mathrm{Hg}^{1+}{ }_{6} \mathrm{Hg}^{2+}[\mathrm{Cl},(\mathrm{OH})]_{2} \mathrm{O}_{3}$ - a new mineral from the Clear Creek claim, San Benito County, California: Description and crystal structure. Powder Diffract 11(1):45-50. https://doi.org/10. 1017/S0885715600008915

Roberts AC, Groat LA, Raudsepp M, Scott Ercit T, Erd RC, Moffat EA, Stirling JAR (2001) Clearcreekite, a new polymorph of $\mathrm{Hg}^{1+}{ }_{3}\left(\mathrm{CO}_{3}\right)(\mathrm{OH}) \cdot 2 \mathrm{H}_{2} \mathrm{O}$, from the Clear Creek claim, San Benito county, California. Can Mineral 39(3):779-784. https://doi.org/10. 2113/gscanmin.39.3.779

Roberts AC, Cooper MA, Hawthorne FC, Criddle AJ, Stirling JAR, Dunning GE (2002) Tedhadleyite, $\mathrm{Hg}^{2+} \mathrm{Hg}^{1+}{ }_{10} \mathrm{O}_{4} \mathrm{I}_{2}(\mathrm{Cl}, \mathrm{Br})_{2}$, a new mineral species from the Clear Creek Claim, San Benito County, California. Can Mineral 40(3):909-914. https://doi.org/ 10.2113/gscanmin.40.3.909

Roberts AC, Cooper MA, Hawthorne FC, Stirling JAR, Paar WH, Stanley CJ, Dunning GE, Burns PC (2003) Vasilyevite, $\left(\mathrm{Hg}_{2}\right)^{2+}{ }_{10} \mathrm{O}_{6} \mathrm{I}_{3} \mathrm{Br}_{2} \mathrm{Cl}\left(\mathrm{CO}_{3}\right)$, a new mineral species from the clear creek claim, San Benito County, California. Can Mineral 41(5): 1167-1172. https://doi.org/10.2113/gscanmin.41.5.1167

Roberts AC, Stirling JAR, Criddle AJ, Dunning GE, Spratt J (2004) Aurivilliusite, $\mathrm{Hg}^{2+} \mathrm{Hg}^{1+} \mathrm{OI}$, a new mineral species from the Clear Creek claim, San Benito County, California, USA. Mineral Mag 68(2):241-245. https://doi.org/10.1180/0026461046820184

Rocha L, De Oliveira J, Barrocas Dias C, Mirão J, Dias L, Manhita A (2018) On the presence of exotic materials in some funerary megalithic monuments in Alentejo: the cases of cinnabar and amber. In: Cruz A, Gibaja JF (eds) Interchange in pre- and protohistory. case studies in Iberia, Romania, Turkey and Israel, 2891st edn. BAR International Series, Oxford, pp 83-90

Rodríguez J, Montero-Ruiz I, Hunt-Ortiz M, García-Pavón E (2020) Cinnabar provenance of Chalcolithic red pigments in the Iberian Peninsula: a lead isotope study. Geoarchaeology 35(6):871-882. https://doi.org/10.1002/gea.21810

Rogerio-Candelera MÁ, Herrera LK, Miller AZ, García Sanjuán L, Mora Molina C, Wheatley DW, Justo Á, Saiz-Jimenez C (2013) Allochthonous red pigments used in burial practices at the Copper Age site of Valencina de la Concepción (Sevilla, Spain): 
characterisation and social dimension. $J$ Archaeol Sci 40(1):279290. https://doi.org/10.1016/j.jas.2012.08.004

Roldán C, Ferrero JL, García Borja P, Domingo Sanz I (2008) Aportaciones al uso de pigmentos durante el Neolítico antiguo en las comarcas centrales valencianas. In: Rovira S, García-Heras M, Gener M, Montero I (Eds.) Actas del VII Congreso Ibérico de Arqueometría Madrid, pp. 669-679.

Romero-Pastor J, Durán A, Rodríguez-Navarro AB, Van Grieken R, Cardell C (2011a) Compositional and quantitative microtextural characterization of historic paintings by micro-X-ray diffraction and raman microscopy. Anal Chem 83(22):8420-8428. https://doi. org $/ 10.1021 /$ ac $201159 \mathrm{e}$

Romero-Pastor J, Cardell C, Manzano E, Yebra-Rodríguez Á, Navas N (2011b) Assessment of Raman microscopy coupled with principal component analysis to examine egg yolk-pigment interaction based on the protein C-H stretching region $\left(3100-2800 \mathrm{~cm}^{-1}\right)$. J Raman Spectrosc 42(12):2137-2142. https://doi.org/10.1002/jrs.2977

Romero-Pastor J, Navas N, Kuckova S, Rodríguez-Navarro A, Cardell C (2012) Collagen-based proteinaceous binder-pigment interaction study under UV ageing conditions by MALDI-TOF-MS and principal component analysis. J Mass Spectrom 47(3):322-330. https:// doi.org/10.1002/jms.2966

Ropret P, Zoubek R, Škapin AS, Bukovec P (2007) Effects of ageing on different binders for retouching and on some binder-pigment combinations used for restoration of wall paintings. Mater Charact 58(11-12 SPEC. ISS):1148-1159. https://doi.org/10.1016/j. matchar.2007.04.027

Roqué J, Molera J, Cepriá G, Vendrell-Saz M, Pérez-Arantegui J (2008) Analytical study of the behaviour of some ingredients used in lustre ceramic decorations following different recipes. Phase Transit 81(23):267-282. https://doi.org/10.1080/01411590701514441

Rosół R (2018) The Greek name of cinnabar. Eos (Poland) 105(2):311322

Ross CP (1942) Some concepts on the geology of quick-silver deposits in the United States. Econ Geol 37(6):439-465. https://doi.org/10. 2113/gsecongeo.37.6.439

Rudnick RL, Gao S (2004) Composition of the continental crust. In: Rudnick RL (Ed.) Treatise on Geochemistry, vol. 3, The Crust. Amsterdam: Elsevier, pp. 1-64.

Rull Perez F., Edwards H. G. M., Rivas A., Drummond L. (1999) Fourier transform Raman spectroscopic characterization of pigments in the mediaeval frescoes at Convento de la Peregrina, Sahagun, Léon, Spain. Part 1 - preliminary study. Journal of Raman Spectroscopy 30(4):301-305. https://doi.org/10.1002/(SICI)10974555(199904)30:4\&1t;301::AID-JRS372\&gt;3.0.CO;2-G

Rytuba JJ (2000) Mercury mine drainage and processes that control its environmental impact. Sci Total Environ 260(1-3):57-71. https:// doi.org/10.1016/S0048-9697(00)00541-6

Rytuba JJ (2003) Mercury from mineral deposits and potential environmental impact. Environ Geol 43(3):326-338. https://doi.org/10. 1007/s00254-002-0629-5

Rytuba JJ, Rye RO, Hernandez AM, Dean JA, Arribas A Sr (1988) Genesis of Almadén-type mercury deposits Almaden, Spain. $28^{\text {th }}$ Int Geol Congress Abstr Program 2:741

Safronov VV, Sozontov EA (2020) Simulation of X-ray fluorescence spectra from a medieval parchment with red ink writing. Results Physics 17:103106. https://doi.org/10.1016/j.rinp.2020.103106

Salvadori, M., Sbrolli, C. (2021) Wall paintings through the ages. The Roman period: Republic and early Empire. Archaeol Anthropol Sci. https://doi.org/10.1007/s12520-021-01411-3

Salvant J, Williams J, Ganio M, Casadio F, Daher C, Sutherland K, Monico L, Vanmeert F, De Meyer S, Janssens K, Cartwright C, Walton M (2018) A Roman Egyptian painting workshop: technical investigation of the portraits from Tebtunis, Egypt. Archaeometry 60(4):815-833. https://doi.org/10.1111/arcm.12351
Sánchez A, Tunón J, Montejo M, Parras D (2012) Micro Raman spectroscopy (MRS) and energy dispersive $\mathrm{x}$-ray microfluorescence $(\mu \mathrm{EDXRF})$ analysis of pigments in the Iberian cemetery of Tutugi (from the fourth to the third century BC, Galera, Granada, Spain). $J$ Raman Spectrosc 43(11):1788-1795. https://doi.org/10.1002/jrs. 4080

Sansonetti A, Striova J, Biondelli D, Castellucci EM (2010) Colored grounds of gilt stucco surfaces as analyzed by a combined microscopic, spectroscopic and elemental analytical approach. Anal Bioanal Chem 397(7):2667-2676. https://doi.org/10.1007/s00216010-3491-4

Saupé Francis, Arnold Michel (1992) Sulphur isotope geochemistry of the ores and country rocks at the Almadén mercury deposit, Ciudad Real, Spain. Geochimica et Cosmochimica Acta 56(10):3765-3780. https://doi.org/10.1016/0016-7037(92)90169-J

Schele L, Mathews P (1999) The Code of Kings: the language of Seven Sacred Maya temples and tombs. Scribner, New York, p 432

Schleid T, Lauxmann P, Schneck C (1999) Röntgenographische einkristallstruktur-untersuchungen an a-HgS (Zinnober). Z Krist 95(Suppl. 16):95

Sedat DW, López F (2004) Initial stages in the formation of the Copan Acropolis. In: Bell EE, Canuto MA, Sharer RJ (eds) Understanding Early Classic Copan. University of Pennsylvania Museum, Philadelphia, pp 85-100

Sepúlveda M, Pozzi-Escot D, Falcón RA, Bermeo N, Lebon M, Moulhérat C, Sarrazin P, Walter P (2020) Unraveling the polychromy and antiquity of the Pachacamac Idol, Pacific coast, Peru. PLoS One 15(1):e0226244. https://doi.org/10.1371/journal.pone.0226244

Serafima S, Duliu OG, Manea M-M, Vasilica S, Radulescu C, Constantinescu B, Stan D, Culicov O-A, Zincovscaia I (2019) Complex investigation of the five $19^{\text {th }}$ century Russian-Lipovan icons. Microchem J 150:104126. https://doi.org/10.1016/j.microc. 2019.104126

Serhrouchni GI, Hajji L, Talbi M, Lhassani A, El Kouali MH, Pessanha S, Carvalho ML, Manso M (2019) Multi-analytical study of $14^{\text {th }}$ to $19^{\text {th }}$ century illuminated Moroccan manuscripts. Eur Physical J Plus 134(10):542. https://doi.org/10.1140/epjp/i2019-12896-2

Sharer R, Traxler L, Sedat D, Bell E, Canuto M, Powell C (1999) Early Classic architecture beneath the Copan acropolis: A research update. Anc Mesoam 10(1):3-23

Sharma RC, Chang YJL, Guminski C (1993) The Hg-S (mercury-sulfur) system. $J$ Phase Equilibria 14:100-109. https://doi.org/10.1007/ BF02652168

Shepherd R (1980) Prehistoric mining and allied industries. Academic Press, London

Shi J-L, Li T (2013) Technical investigation of $15^{\text {th }}$ and $19^{\text {th }}$ century Chinese paper currencies: fiber use and pigment identification. $J$ Raman Spectrosc 44(6):892-898. https://doi.org/10.1002/jrs.4297

Siddall, R. (2018) Mineral pigments in archaeology: their analysis and the range of available materials. Minerals 8: 201. https://doi.org/10. $3390 / \min 8050201$

Singh MR, Sharma D (2020) Investigation of pigments on an Indian palm leaf manuscript $\left(18^{\text {th }}-19^{\text {th }}\right.$ century) by SEM-EDX and other techniques. Restaurator 41(1):46-95. https://doi.org/10.1515/res-20190006

Škapin AS, Ropret P, Bukovec P (2007) Determination of pigments in colour layers on walls of some selected historical buildings using optical and scanning electron microscopy. Mater Charact 58(11-12 SPEC. ISS):1138-1147. https://doi.org/10.1016/j.matchar.2007.05. 013

Smith AD, Pradell T, Roqué J, Molera J, Vendrell-Saz M, Dent AJ, Pantos E (2006) Color variations in $13^{\text {th }}$ century hispanic lustre an EXAFS study. J Non-Cryst Solids 352(50-51):5353-5361. https://doi.org/10.1016/j.jnoncrysol.2006.08.024 
Smith CS, Hawthorne JG (1974) Mappae Clavicula: a little key to the world of medieval techniques. Transactions of the American Philosophical Society 64(4): 1-128.

Sodo A, Artioli D, Botti A, De Palma G, Giovagnoli A, Mariottini M, Paradisi A, Polidoro C, Ricci MA (2008) The colours of Etruscan painting: a study on the Tomba dell'Orco in the necropolis of Tarquinia. J Raman Spectrosc 39(8 SPEC. ISS):1035-1041. https://doi.org/10.1002/jrs.1982

Sodo A, Tortora L, Biocca P, Casanova Municchia A, Fiorin E, Ricci MA (2019) Raman and time of flight secondary ion mass spectrometry investigation answers specific conservation questions on Bosch painting Saint Wilgefortis Triptych. J Raman Spectrosc 50(2): 150-160. https://doi.org/10.1002/jrs.5479

Solla L, Meloni P, Sanna U, Cargangiu G, Cocco O (2015) Pigments and materials across Sardinias walls: Contribution on the Tomba dei Pesci e delle Spighe in Cagliari. Periodico di Mineralogia 84(3A): 453-464. https://doi.org/10.2451/2015PM0025

Song Y, Gao F, Nevin A, Guo J, Zhou X, Wei S, Li Q (2018) A technical study of the materials and manufacturing process used in the Gallery wall paintings from the Jokhang temple, Tibet. Heritage Science 6(1): 18. https://doi.org/10.1186/s40494-018-0182-5

Spangenberg JE, Lavrič JV, Meisser N, Serneels V (2010) Sulfur isotope analysis of cinnabar from Roman wall paintings by elemental analysis/isotope ratio mass spectrometry - tracking the origin of archaeological red pigments and their authenticity. Rapid Commun Mass Spectrom 24(19):2812-2816. https://doi.org/10.1002/rcm. 4705

Spring S, Grout R (2002) The blackening of vermilion: an analytical study of the process in paintings. Nat Gallery Techn Bull 23:50-61

Stamboliyska B., Tapanov S., Velcheva E., Yancheva D., Rogozherov M., Glavcheva Z., Lalev G., Dimitrov M. (2021) The altar wall paintings of the catholicon "The Nativity of the Virgin", Rila Monastery, Bulgaria: Identification of the painting materials by means of vibrational spectroscopic techniques complemented by EDX, XRD and TGA analysis. Spectrochimica Acta Part A: Molecular and Biomolecular Spectroscopy 247:119087. https:// doi.org/10.1016/j.saa.2020.119087

Steger S, Oesterle D, Mayer R, Hahn O, Bretz S, Geiger G (2019a) First insights into Chinese reverse glass paintings gained by non-invasive spectroscopic analysis - tracing a cultural dialogue. Archaeol Anthropol Sci 11(8):4025-4034. https://doi.org/10.1007/s12520019-00799-3

Steger S, Oesterle D, Bretz S, Frenzel L, Stege H, Winkelmeyer I, Hahn O, Geiger G (2019b) Kandinsky's fragile art: a multidisciplinary investigation of four early reverse glass paintings (1911-1914) by Wassily Kandinsky. Heritage Sci 7(1):27. https://doi.org/10.1186/ s40494-019-0268-8

Steger S, Bretz S, Stege H, Hahn O (2019c) Methodological approach for in situ spectroscopic analysis of modern reverse paintings on glass: a case study of Kreuzabnahme (1914/15) - an outstanding example by Carlo Mense. Eur Physical J Plus 134(2):64. https://doi.org/10. 1140/epjp/i2019-12549-6

Stojanović SR, Gajić-Kvaščev MD, Damjanović LS (2015) Spectroscopic study of an icon painted on wooden panel | [Spektroskopsko ispitivanje ikone slikane na drvenom nosiocu]. Hemijska Ind 69(4):387-393 (Bosnian). https://doi.org/10.2298/ HEMIND140430053S

Strahan D, Tsukada M (2016) Measuring mercury emissions from cinnabar lacquer objects. Stud Conserv 61:166-172. https://doi.org/10. 1080/00393630.2016.1227048

Švarcová S, Hradil D, Hradilová J, Čermáková Z (2021) Pigments Copper-based greens and blues. Archaeol Anthropol Sci. https:// doi.org/10.1007/s12520-021-01406-0

Swiderski RM (2008) Calomel in America: mercurial panacea, war, song and ghosts. Brown Walker Press, Boca Raton
Szczepanowska H, Fitzhugh EW (1999) Fourteenth-century documents of the Knights of St. John of Jerusalem: analysis of inks, parchment and seals. Paper Conserv 23:36-45. https://doi.org/10.1080/ 03094227.1999 .9638615

Takamatsu T (1878) On Japanese pigments. Graduating thesis. Tokyo: Department of Science in Daigaku

Tamburini D, Kotonski V, Lluveras-Tenorio A, Colombini MP, Green A (2019) The evolution of the materials used in the yun technique for the decoration of Burmese objects: lacquer, binding media and pigments. Heritage Sci 7:28. https://doi.org/10.1186/s40494-0190272-z

Tate Jim, Reiche I., Pinzari F., Clark J., Caldwell D. (2011) History and Surface Condition of the Lewis Chessmen in the Collection of the National Museums Scotland (Hebrides, late 12th-early 13th centuries). ArchéoSciences (35):249-258. https://doi.org/10. 4000/archeosciences.3342

Tiesler V, Cucina A (2006) Janaab' Pakal of Palenque: reconstructing the life and death of a Maya ruler. University of Arizona Press, Tucson

Tite MS, Freestone IC, Mason R, Molera J, Vendrell-Saz M, Wood N (1998) Lead glazes in Antiquity - methods of production and reasons for use. Archaeometry 40(2):241-260. https://doi.org/10.1111/ j.1475-4754.1998.tb00836.x

Torres Montes L (1972) Materiales y técnicas de la pintura mural de Teotihuacán. In: Memorias de la XI Mesa Redonda SMA Teotihuacan. El Valle de Teotihuacán y su contorno. México: Sociedad Mexicana de Antropologia, pp. 17-42.

Trinquier J (2013) Cinnabaris et «sang-dragon»: Le «cinabre» des Anciens entre minéral, végétal et animal. Revue Archeol 56(2): 305-346. https://doi.org/10.3917/arch.132.0305

Truhan DL, Burton JH, Bruhns KO (2005) El cinabrio en el mundo Andino. Rev Antropol 18:194-206

Tsantini E, Minami T, Takahashi K, Ontiveros MÁC (2018) Analysis of sulphur isotopes to identify the origin of cinnabar in the Roman wall paintings from Badalona (Spain). J Archaeol Sci Rep 18:300-307. https://doi.org/10.1016/j.jasrep.2018.01.032

Tsatsouli Konstantina, Nikolaou Elisavet (2018) The ancient Demetrias figurines: new insights on pigments and decoration techniques used on Hellenistic clay figurines. STAR: Science \& Technology of Archaeological Research 3(2):341-357. https://doi.org/10.1080/ 20548923.2018.1424302

Tuñón JA, Sánchez A, Parras DJ, Vandenabeele P, Montejo M (2016) Micro-Raman spectroscopy on Iberian archaeological materials. $J$ Raman Spectrosc 47(12):1514-1521. https://doi.org/10.1002/jrs. 4934

Vandenabeele P, Bodé S, Alonso A, Moens L (2005) Raman spectroscopic analysis of the Maya wall paintings in Ek'Balam, Mexico. Spectrochimica Acta - Part A: Molecular and Biomolecular Spectroscopy 61(10):2349-2356. https://doi.org/10.1016/j.saa. 2005.02 .034

Vanmeert F, De Nolf W, Dik J, Janssens K (2018) Macroscopic X-ray powder diffraction scanning: possibilities for quantitative and depthselective parchment analysis. Anal Chem 90(11):6445-6452. https:// doi.org/10.1021/acs.analchem.8b00241

Vargas Jiménez JM (2004) Carta Arqueológica Municipal de Valencina de la Concepción. Junta de Andalucía, Sevilla

Vasić MM (1932-1936) Preistoriska Vinča, I-IV. Beograd : izdanje i štampa državne štamparije Kraljevine Jugoslavije (Serbian).

Vázquez de Ágredos Pascual ML (2004) El papel de las tierras naturales en la pintura mural prehispánica: CIENCIA y arte en la paleta cromática. Boletín Informativo del Instituto de Investigaciones Estétecas-UNAM 20:57-64

Vázquez de Ágredos Pascual ML (2007) Los colores y las técnicas de la pintura mural Maya. Anal del Museo de Am 15:55-66 
Vázquez de Ágredos Pascual ML (2009) El color y lo funerario entre los mayas de ayer y hoy. Ritual, magia y cotidianeidad. Peninsula 4(1): $61-73$

Vázquez De Ágredos Pascual ML (2018) Painting the skin in Ancient Mesoamerica. In: Vázquez De Ágredos Pascual ML, Dupey García É (eds) Painting the skin: pigments on bodies and codices in PreColumbian Mesoamerica. University of Arizona Press, TucsonMexico City, p 384. https://doi.org/10.2307/j.ctvgs09xv

Vázquez De Ágredos Pascual ML, Dupey García É (eds) (2018) Painting the Skin: Pigments on Bodies and Codices in Pre-Columbian Mesoamerica. University of Arizona Press, Tucson-Mexico City, pp 11-23. https://doi.org/10.2307/j.ctvgs09xv.6

Vázquez de Ágredos Pascual ML, Manzanilla Naim LR, López Puértolas C (2018) Capítulo 11: Color y cultura en Teotihuacan. Los pigmentos y colorantes de Teopancazco como caso de estudio. In: Manzanilla LR (Ed.) Teopancazco como centro de barrio multiétnico de Teotihuacan. Los sectores funcionales y el intercambio a larga distancia. Mexico: Instituto de Investigaciones Antropológicas-UNAM, pp. 387-419.

Vázquez de Ágredos Pascual MLV, Roldán-García C, Murcia-Mascarós S, Juanes Barber D, Jaén Sánchez MG, Faugère B, Darras V (2019) Multianalytical characterization of pigments from funerary artefacts belongs to the Chupicuaro Culture (Western Mexico): oldest Maya blue and cinnabar identified in Pre-Columbian Mesoamerica. Microchem J 150:104101. https://doi.org/10.1016/j.microc.2019. 104101

Vermeulen M, Sanyova J, Janssens K (2015) Identification of artificial orpiment in the interior decorations of the Japanese tower in Laeken, Brussels, Belgium. Heritage Sci 3(9):3-9. https://doi.org/10.1186/ s40494-015-0040-7

Villar SEJ, Edwards HGM (2005) An extensive colour palette in Roman villas in Burgos, Northern Spain: a Raman spectroscopic analysis. Anal Bioanal Chem 382(2):283-289. https://doi.org/10.1007/ s00216-004-2876-7

Vitti P (2021) Mortars and masonry - Structural lime and gypsum mortars in Antiquity and Middle Ages. Archaeol Anthropol Sci. https://doi. org/10.1007/s12520-021-01408-y

Vlachou-Mogire C, Moretti P, Monico L, Chieli A, Iwanicka M, Targowski P, Detalle V, Bourguignon E, Laclavetine K, Mirambet F, Tong T, Pinchin S (2020) A non-invasive multi-technique investigation of Banqueting House Whitehall Rubens ceiling paintings. Microchem J 156:104797. https://doi.org/10.1016/j.microc.2020. 104797

Vlad A-M, Ursescu M, Măluțan T, Puiu P, Ciovică S (2011) Regional stylistic and technical variations in some Romanian manuscripts. Eur J Sci Theol 7(1):91-102

Wang X, Wang C, Yang J, Chen L, Feng J, Shi M (2004) Study of wallpainting pigments from Feng Hui Tomb by Raman spectroscopy and high-resolution electron microscopy. J Raman Spectrosc 35(4):274-278. https://doi.org/10.1002/jrs.1147

Wang N, He L, Egel E, Simon S, Rong B (2014) Complementary analytical methods in identifying gilding and painting techniques of ancient clay-based polychromic sculptures. Microchem $J$ 114:125140. https://doi.org/10.1016/j.microc.2013.12.011

Wang N, He L, Zhao X, Simon S (2015) Comparative analysis of eastern and western drying-oil binding media used in polychromic artworks by pyrolysis-gas chromatography/mass spectrometry under the influence of pigments. Microchem J 123:201-210. https://doi.org/ 10.1016/j.microc.2015.06.007

Wang N, Zhang T, Min J, Li G, Ding Y, Liu J, Gu A, Kang B, Li Y, Lei Y (2018) Analytical investigation into materials and technique: carved lacquer decorated panel from Fuwangge in the Forbidden City of Qianlong Period, Qing Dynasty. J Archaeol Sci Rep 17:529-537. https://doi.org/10.1016/j.jasrep.2017.12.023

Wang L-Q, Ma Y-N, Zhang Y-X, Zhao X, He Q-J, Guo J-Y, Ren H-T (2020) Pigment identification of sleeping buddha at World Cultural Heritage Dazu Rock Carvings with $\mu$-Raman spectroscopy and related research. Guang Pu Xue Yu Guang Pu Fen Xi/Spectroscopy Spectral Anal 40(10):3199-3204 (Chinese). https://doi.org/10.3964/ j.issn.1000-0593(2020)10-3199-06

Watkins JK, Blatt SH, Bradbury CA, Alanko GA, Kohn MJ, Lytle ML, Taylor J, Lacroix D, Nieves-Colón MA, Stone AC, Butt DP (2017) Determining the population affinity of an unprovenienced human skull for repatriation. J Archaeol Sci Rep 12:384-394. https://doi. org/10.1016/j.jasrep.2017.02.006

Wei S, Schreiner M, Guo H, Ma Q (2010) Scientific investigation of the materials in a Chinese Ming dynasty wall painting. Int J Conserv Sci 1(2):99-112

Wei S, Ma Q, Schreiner M (2012) Scientific investigation of the paint and adhesive materials used in the Western Han dynasty polychromy terracotta army, Qingzhou, China. J Archaeol Sci 39(5):16281633. https://doi.org/10.1016/j.jas.2012.01.011

Westphal KR (1997) Affinity, idealism, and naturalism: the stability of Cinnabar and the possibility of experience. Kant-Studien 88(2):139189. https://doi.org/10.1515/kant.1997.88.2.139

Wu X-H, Sun D-H, Zhuang Z-X, Wang X-R, Gong H-F, Hong J-X, Lee FSC (2002) Analysis and leaching characteristics of mercury and arsenic in Chinese medicinal material. Anal Chim Acta 453(2):311323. https://doi.org/10.1016/S0003-2670(01)01442-8

Wyckoff RWG (1963) Crystal Structures 1, 2nd edn. Interscience Publishers, New York, pp 85-237

Yamada M-O, Minami T, Yamada G, Tohno Y, Tohno S, Ikeda Y, Tashiro T, Kohno Y, Kawakami K (1997) Different element ratios of red cosmetics excavated frorm ancient burials of Japan. Sci Total Environ 199(3):293-298. https://doi.org/10.1016/S0048-9697(97) 05474-0

Zannini P, Baraldi P, Aceto M, Agostino A, Fenoglio G, Bersani D, Canobbio E, Schiavon E, Zanichelli G, De Pasquale A (2012) Identification of colorants on XVIII century scientific handcoloured print volumes. J Raman Spectrosc 43(11):1722-1728. https://doi.org/10.1002/jrs.4119

Zhao HX, Li QH, Liu S, Hu YQ, Gan FX (2014) Nondestructive analysis of jade artifacts from the Cemetery of the Ying State in Henan Province, China using confocal Raman microspectroscopy and portable X-ray fluorescence spectroscopy. J Raman Spectrosc 45(2): 173-178. https://doi.org/10.1002/jrs.4435

Zheng L, Wang L, Zhao X, Yang J, Zhang M, Wang Y (2020) Characterization of the materials and techniques of a birthday inscribed lacquer plaque of the Qing dynasty. Heritage Sci 8(1): 116. https://doi.org/10.1186/s40494-020-00462-4

Publisher's note Springer Nature remains neutral with regard to jurisdictional claims in published maps and institutional affiliations. 